Portland State University

PDXScholar

Fall 12-14-2012

\title{
Stream-Associated Amphibian Habitat Assessment in the Portland-Vancouver Metropolitan Region
}

Andrew Evans Dietrich

Portland State University

Follow this and additional works at: https://pdxscholar.library.pdx.edu/open_access_etds

Part of the Environmental Sciences Commons, Fresh Water Studies Commons, and the Terrestrial and Aquatic Ecology Commons

Let us know how access to this document benefits you.

\section{Recommended Citation}

Dietrich, Andrew Evans, "Stream-Associated Amphibian Habitat Assessment in the Portland-Vancouver Metropolitan Region" (2012). Dissertations and Theses. Paper 604.

https://doi.org/10.15760/etd.604

This Thesis is brought to you for free and open access. It has been accepted for inclusion in Dissertations and Theses by an authorized administrator of PDXScholar. Please contact us if we can make this document more accessible: pdxscholar@pdx.edu. 
Stream-Associated Amphibian Habitat Assessment in the Portland-

Vancouver Metropolitan Region

by

Andrew Evans Dietrich

A thesis submitted in partial fulfillment of the requirements for the degree of

\author{
Master of Science \\ in \\ Environmental Science and Management
}

Thesis Committee:

J. Alan Yeakley, Chair

Catherine deRivera

Martin Lafrenz

Portland State University

2012 
(C) 2012 Andrew Evans Dietrich 


\begin{abstract}
This study assessed the influence of landscape development on streamassociated amphibians in forested riparian areas within the Portland-Vancouver metropolitan region. Human alteration of landscapes may dramatically affect the ecology of neighboring aquatic systems. It was hypothesized that lotic amphibians would be negatively associated with greater amounts of landscape development and positively associated with forested area within the surrounding watershed. Thirtyseven $1^{\text {st }}-3^{\text {rd }}$ order streams were sampled between June $21^{\text {st }}$ and September $21^{\text {st }}$ in 2011. Streams potentially providing adequate habitat for stream-obligate amphibians were randomly selected. Amphibians were surveyed along 30-meter stream transects using an active-cover search (ACS). Environmental variables associated with development in surrounding landscapes were measured in situ. GIS delineation was conducted to define landscape-scale variables at stratified distances from riparian networks up-stream of each site via the utilization of the 2006 NLCD dataset and a finer-scale, regional dataset compiled by the Institute for Natural Resources (INR). Amphibians were detected at seventeen of the thirty-seven sampled streams. The most commonly detected species were Dicamptadon tenebrosus, Plethadon vehiculum and Plethadon dunni. Streams where amphibians were observed had lower average water temperature and conductivity, coarser stream substrate, and were located on public property more often than streams where no amphibians were detected. Landscape variables within 100 and 200 meters of the upstream stream network influenced amphibians most significantly.
\end{abstract}


Occupancy of a site by facultative species was best explained by the proportion of mixed forest in the surrounding watershed $\left(\mathrm{R}^{2}=0.34, \mathrm{p}<0.001\right)$. Occupancy of a stream by obligate species was best predicted by measurements of water quality and in-stream cover (Water Temperature: $\mathrm{R}^{2}=0.28, \mathrm{p}<0.001$; Water Conductivity: $\mathrm{R}^{2}=0.25, \mathrm{p}<0.001$; Cover: $\left.\mathrm{R}^{2}=0.32, \mathrm{p}<0.001\right)$. Occupancy of stream refugia by all observed amphibians was positively influenced by higher percentages of forest cover and by lower percentages of urban development and herbaceous vegetation in the surrounding watershed. Results of this study indicate that urban amphibian refugia must contain adequate riparian forest area, coarse stream substrate and clean, cool water to sustain stream-amphibian communities. This study demonstrates that protection of remnant forested headwater stream networks is essential to the conservation of lotic amphibians in urbanized regions. 


\section{Dedication}

I dedicate this thesis to Sara, Onyx, my family and friends and everyone else who helped keep me sane through my graduate school experience. 


\section{Acknowledgments}

I would like to thank my advisor, Alan Yeakley, for his support, guidance and wisdom throughout my time at Portland State. It has been a pleasure to be your advisee. I would like to thank my other committee members, Cat deRivera and Martin Lafrenz, for their helpful feedback, flexibility and support. Thank you also to Yangdong Pan for your invaluable critique during my thesis proposal process. I would also like to thank the rest of the faculty and staff in the Environmental Science and Management Department for providing interesting courses, endless help and a sense of community. In particular, a big thank you to Teri and Sherie for always being available to solve any problem.

In addition, I could not have completed this thesis without the invaluable aid of Christa von Behren and our field technicians (Ben Burton, Jose Herrera, Stephanie Zhao, Megan Mao, and William Kerney) and volunteers (Gunnar Johnson, Jennifer Thompson). I am also grateful for the advice and support of all my Yeakley Lab colleagues (Sarah Holman, Denisse Fisher, Christa and Gunnar).

Lastly, I would like to thank all of those who made this research possible, including the home-owners who generously allowed us to access their properties and the public works agencies who graciously allowed us to sample within their parks and green-spaces. 


\section{Table of Contents}

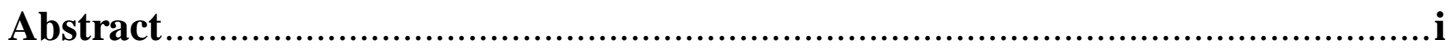

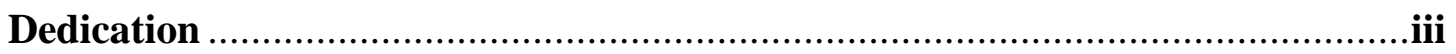

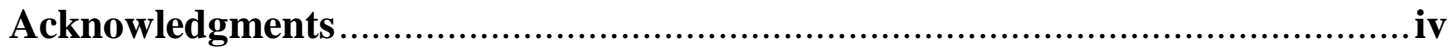

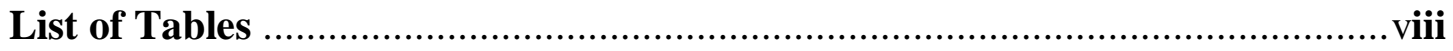

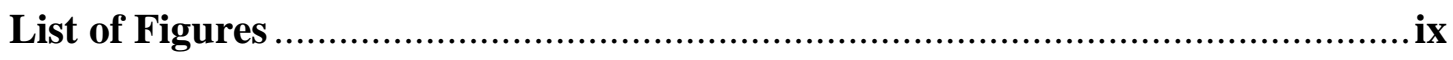

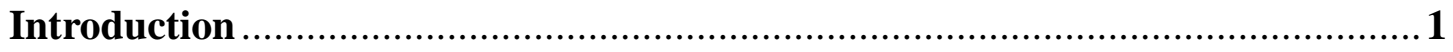

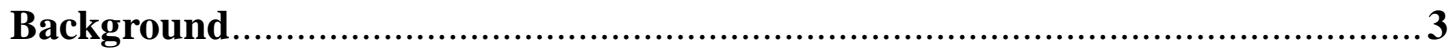

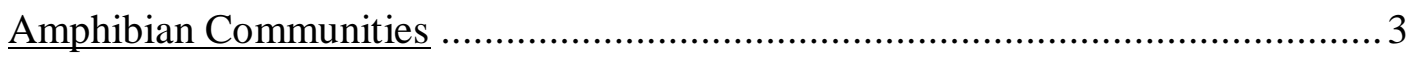

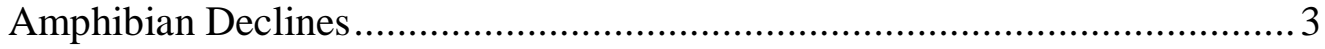

Stream-Associated Amphibians.......................................................... 4

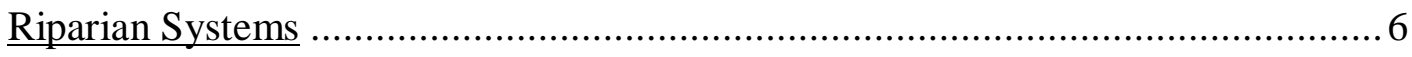

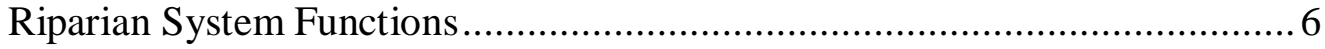

Riparian System Threats and Conservation ………....................................... 6

Characterization of Riparian Systems in the Pacific Northwest...................... 7

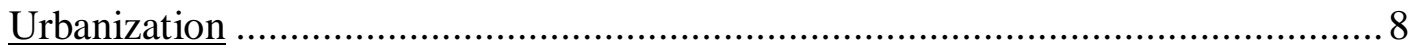

General Impacts of Urbanization on Riparian Areas .................................... 8

Landscape Development: Impacts to Aquatic Systems \& Amphibians ........... 9

Amphibian Conservation and Riparian Buffer Requirements.......................... 10

Urbanization of the Portland, OR and Clark County, WA Regions ................. 11

Riparian Refugia and Amphibian Communities in the Portland-Vancouver Region

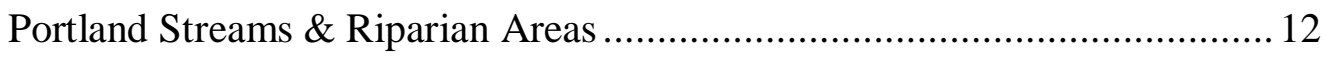

Amphibians in the Portland, OR Region....................................................... 14

Potential Habitat for Lotic Amphibians in the Portland-Vancouver Region .. 16

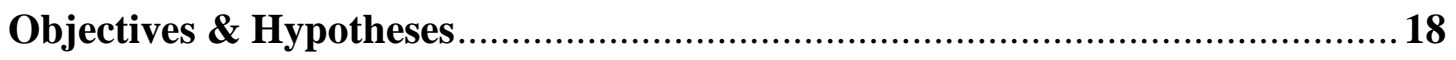

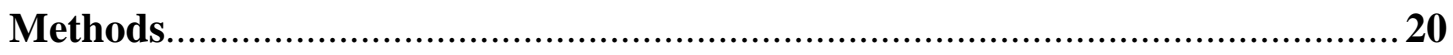

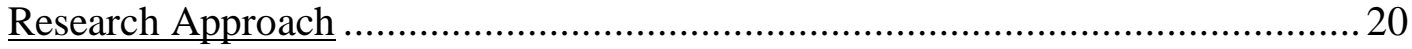

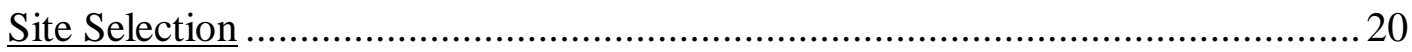

Preliminary Habitat Requirements for Site Selection ...................................2 21 
Site Selection through ArcGIS Analysis ............................................... 22

Site Ownership and Access Determination ........................................ 24

Transect Establishment and In-situ Field Sampling ..................................... 27

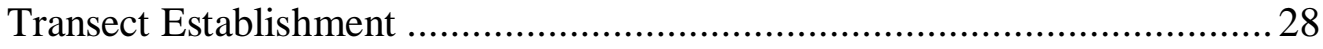

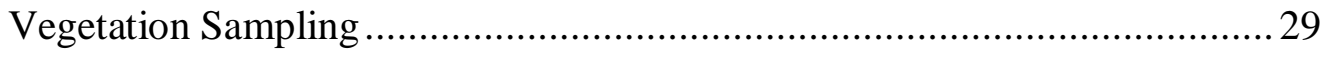

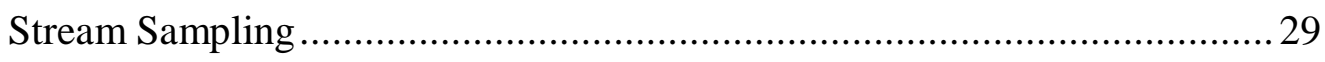

Amphibian Sampling …................................................................ 31

Biogeographic Parameter Sampling Via Spatial Analysis ................................ 33

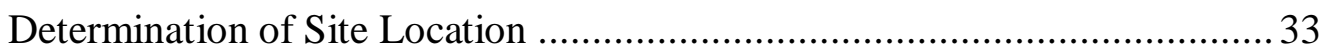

Stream-Reach Variable Collection .................................................... 34

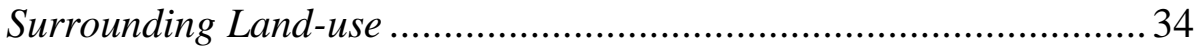

Proximity to Road Crossing ....................................................... 36

Forested Patch Size Delineation .............................................. 36

Sub-watershed Variable Collection ........................................................ 38

Sub-watershed Delineation .......................................................... 38

Surrounding Land-use within the Sub-watershed .......................... 42

Impervious Surface Calculation ..................................................... 43

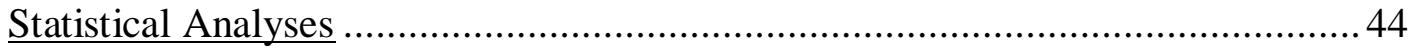

Non-Metric Dimensional Scaling .............................................. 44

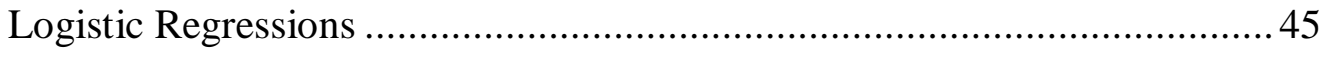

Contingency Tables for Categorical Variables..................................... 46

Occupancy Modeling with the PRESENCE Program ............................. 47

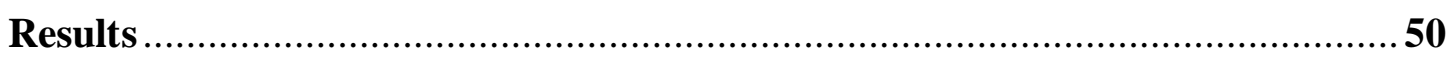

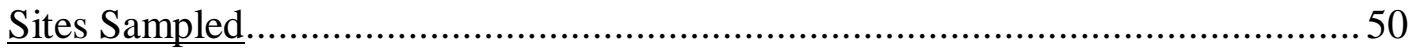

Amphibian Detections......................................................... 50

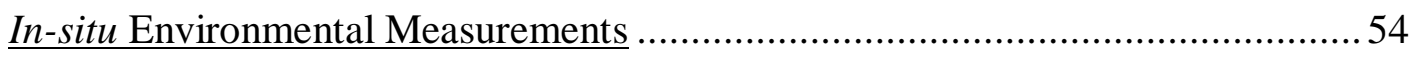

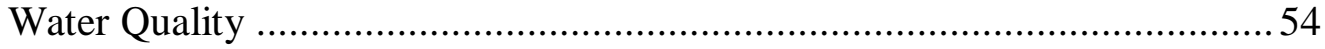

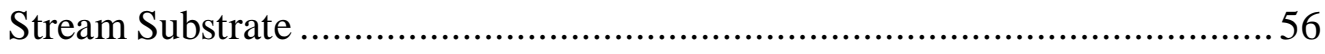

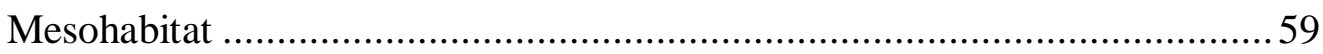




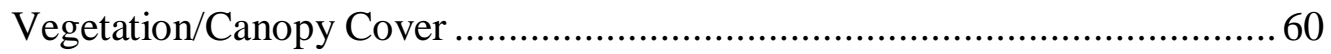

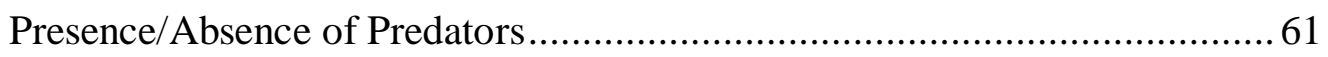

Biogeographic Environmental Measurements............................................. 61

Distance to Nearest Road .................................................................... 61

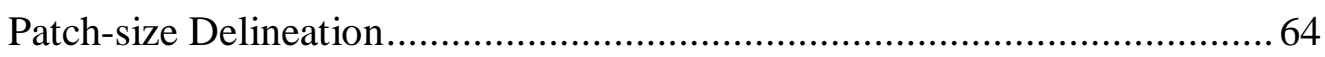

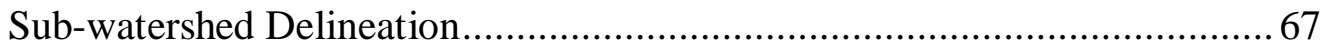

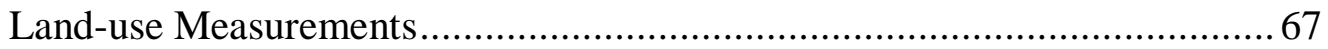

Statistical Analyses: Environmental Variables Significant to Amphibian Occupancy

Non-Metric Dimensional Scaling .................................................. 72

Logistic Regression of Significant Variables ........................................ 76

Contingency Tables for Categorical Variables....................................... 82

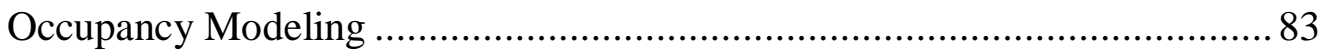

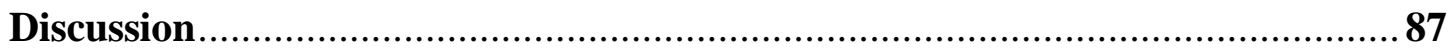

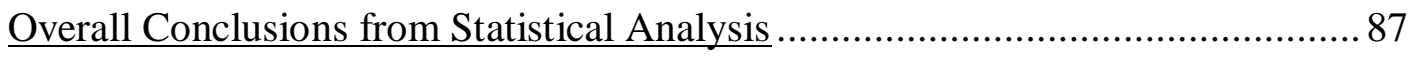

Relating Results to the Hypotheses................................................... 88

Amphibian Habitat Requirements.............................................................. 89

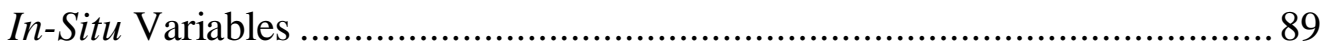

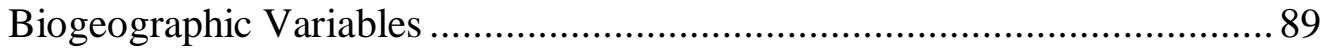

Presence/Absence Modeling Trends and Anomalies ..................................... 92

Amphibian Conservation and Future Studies ............................................... 96

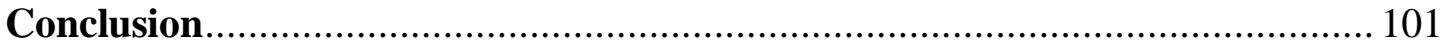

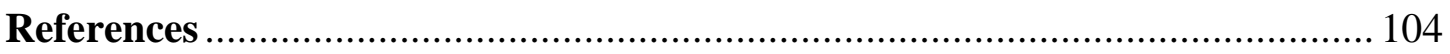

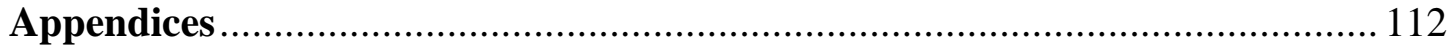

Appendix A - Potential Environmental Parameters Affecting Stream Amphibians

Appendix B - Amphibians Endemic to the Portland-Vancouver Region.............. 113

Appendix C - Mailing Postcard Example ................................................ 114

Appendix D - Transect Location Adjustment Justifications ............................ 115

Appendix E - Amphibian Detection Raw Data................................................ 116 
Appendix F - In-situ Environmental Variables Raw Data............................... 118

Appendix G - Additional Vectors Included in NMDS Analysis........................ 120

Appendix H - Logistic Regression Null Hypothesis Testing Results ................. 121

Appendix I - Occupancy Model Variable Lists ........................................... 122

Appendix J - Occupancy Modeling Model Weight Sums per Variable .............. 123 


\section{List of Tables}

Table 1 - Maximum Distance Traveled by Observed Amphibian Species.......... 36

Table 2 - Variables Included in $\boldsymbol{a}$ priori Models for Occupancy Modeling......... 48

Table 3 - List of Observed Amphibian Species. ........................................... 51

Table 4 - Presence of Predators/Competitors at Sampled Sites. ...................... 61

Table 5 - Environmental Predictors with Significant $\mathbf{R}^{2}$ Values in NMDS

Analysis.

Table 6 - Logistic Regression Model Results for Obligate and Facultative Species Presence/Absence in Relation to Landscape-Scale Variables.

Table 7 - Logistic Regression Model Results for Obligate and Facultative Species

Presence/Absence in Relation to Micro/Meso-Scale Variables.

Table 8 - Estimates and Standard Errors for Variables Tested with Logistic

Regressions.

Table 9 - Fisher's Exact Test Results for Contingency Tables.

Table 10 - Results from the Obligate Species Occupancy Models.....

Table 11 - Results from the Facultative Species Occupancy Models. 


\section{List of Figures}

Figure 1 - Canopy Cover in the Portland-Vancouver Metropolitan Area......... 17

Figure 2 - Kelley and Johnson Creek Sub-watershed Map............................ 26

Figure 3 - Schematic of Amphibian Sampling Transects. ........................... 32

Figure 4 - Sub-watershed Delineation Complication Example. ........................ 42

Figure 5 - Map of Site Location in the Portland-Vancouver Metropolitan Area.

Figure 6 - Map of Amphibian Species Richness Values for Sampled Sites.........53

Figure 7 -Water Temperature by Amphibian Functional Group....................55

Figure 8 - Specific Conductivity by Amphibian Functional Group..................56

Figure 9 - Substrate Composition Graphed by Amphibian Groups Observed. . 57

Figure 10 -Number of Cover Objects Searched per Transect by Amphibian

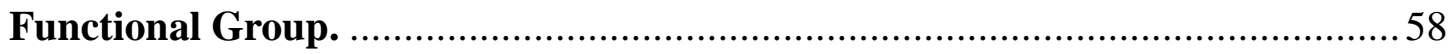

Figure 11 - Meso-habitat Ratio Among Sampled Sites Graphed by Amphibian

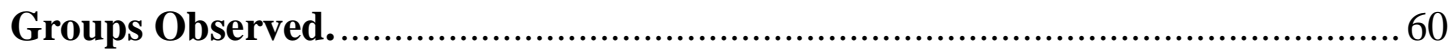

Figure 12 - Distance to Nearest Road Crossing Upstream and Downstream by Amphibian Functional Group.

Figure 13 - Distance to Nearest Road Crossing by Amphibian Functional

Group.

Figure 14 - Forest Patch Area and Edge Habitat by Amphibian Functional Group.

Figure 15 - Map of Sub-watersheds Delineated for Each Sampled Site.

Figure 16 - Land-use Ratios within 50 meter and 100 meter Stream Buffers

Graphed by Amphibian Functional Groups Observed.

Figure 17 - Land-use Ratios within 200 meter and 300 meter Stream Buffers Graphed by Amphibian Functional Groups Observed. 
Figure 18 - Land-use Ratios within the Surrounding Sub-watershed Graphed by Amphibian Functional Groups Observed...................................................... 71

Figure 19 - Non-Metric Dimensional Scaling Graph of Species Abundance Data. .73

Figure 20 - Environmental Vector Non-Metric Dimensional Scaling Plot. ........ 74

Figure 21 - Logistic Regression Result: Obligate Species Presence vs. Mixed

Forest Area within the 200 meter Stream Buffer.

Figure 22 - NMDS Species Groupings and Summarized Vector Axes. ............. 87

Figure 23 - Ratios of Land-use at the Sub-watershed Scale. ........................... 92

Figure 24 - Photographic Example of Stream Obligate Amphibian Habitat. ... 98 


\section{INTRODUCTION}

Amphibians represent an important taxonomic group in many ecosystems, particularly aquatic communities (Whiles et al., 2006; Miller et al., 2007). Unfortunately, many amphibian populations throughout the world are in decline. Attempts to identify the cause of amphibian die-offs have been complicated by interacting variables operating simultaneously within the systems of concern (Carey et al. 2001). In addition, there is an insufficiency in studies attempting to separate landscape effects from influences of local habitat quality (Marsh and Trenham, 2001). If viable conservation strategies are to be developed, it will be necessary to identify habitat features that are conducive to sustaining existing amphibian communities (Crawford and Semlitsch, 2008). Furthermore, a better understanding of factors influencing amphibian dispersal and mortality should be incorporated into management strategies (Cushman, 2006).

All 47 species of amphibians within the Pacific Northwest region of the United States utilize riparian systems. Of these 47 species, one-third are streamobligate species and one-quarter rely specifically on headwater riparian systems (Olson et al., 2007). Significant research has been dedicated to studying the impacts of forestry practices on stream-obligate species in this region (Ashton et al., 2006; Corn and Bury, 1989; Kluber et al., 2008; Kroll et al., 2008; Stoddard and Hayes, 2005; Vesely and McComb, 2002). Conversely, few studies have been conducted to investigate the impacts of urbanization on these same species. 
The Portland-Vancouver metropolitan region encompasses significant proportions of Washington, Mulnomah and Clark counties and includes over 20,000 acres of natural areas (The Intertwine Alliance, 2012). Ten amphibian species have been recently documented in the Portland-Vancouver area (Holzer 2009a, Holzer 2009b), while 16 species have recorded ranges that overlap with the region (Jones et al., 2005; Bartlett and Bartlett, 2009). Though studies have indicated that the natural areas within the metropolitan region are sufficient to sustain some of these amphibian populations, it is unclear whether the riparian refugia in the region are sufficient to sustain populations of stream-obligate species such as the Pacific Giant Salamander (Dicamptadon tenebrosus). This study sought to identify correlations between environmental variables affected by human landscape development and streamamphibian presence to identify habitat characteristics which might influence streamassociated amphibian occupancy of refugia within the region. 


\section{BACKGROUND}

\section{Amphibian Communities}

\section{$\underline{\text { Amphibian Declines }}$}

Many amphibian populations are in decline, with notable collapses of amphibian communities occurring in Australia, Central America and the Pacific Northwest of the United States. Various factors which have been suggested to contribute to these declines include pollution, UV-B Radiation, habitat loss and infectious diseases such as chytrid fungus (Alford and Richards, 1999; Halliday, 2005). However, no single environmental variable has been implicated as a definitive cause for global declines. Furthermore, as mass mortalities have also occurred in relatively undisturbed areas, there exists a need to determine how amphibian declines might be influenced by various human effects on biological systems (Carey et al., 2001), particularly in the context of landscape-scale disturbances.

Certain genera of amphibians seem to be disproportionately affected in recent declines, yet the distributions and habitat of these sensitive genera display no obvious pattern (Crump, 2005). Amphibian declines in North America have predominantly involved pond-breeding species, perhaps due to their tendencies to aggregate in large, often noisy mating clusters (Green, 2005). Terrestrial salamanders of the Plethadon genus have also been identified as declining in recent years, possibly in relation to increased silvicultural activities and other habitat-fragmenting practices (Highton, 2005). The overall status of stream-associated amphibians is less well studied. 


\section{Stream-Associated Amphibians}

Stream-associated amphibians represent an important component of both aquatic and terrestrial systems. Within stream communities, amphibians function as both predator and prey species to aquatic and terrestrial biota. These roles are particularly pronounced in smaller, headwater streams without fish where stream obligate amphibians may represent as much as $99 \%$ of the predator biomass (Welsh Jr. and Ollivier, 1998; Miller et al., 2007). The multiple life-stages of stream obligate amphibians create an important vector for nutrient exchange between aquatic and terrestrial systems (Whiles et al., 2006; Kluber et al., 2008). Additionally, amphibians are relatively long-lived compared to other stream biota and highly philopatric in relation to fish (Welsh Jr. and Ollivier, 1998), enhancing the sensitivity of lotic amphibians to local environmental changes. Facultative stream amphibians, particularly plethadon species, have not been shown to facilitate significant nutrient pathways between terrestrial and aquatic systems or display significant sensitivities to aquatic conditions. However, woodland amphibians can compose the majority of terrestrial vertebrate biomass in forested communities (Crawford and Semlitsch, 2008), particularly in riparian areas where amphibian diversity is concentrated (Vesely and McComb, 2002). In addition, a number of facultative species have narrow environmental tolerances (Wilkins and Peterson, 2000). These characteristics are indicative of the ability of stream-associated amphibian populations to act as an appropriate tool for assessing the quality of both the stream biome and forested riparian zone. 
Within forested headwater communities of the Pacific Northwest, the Pacific Giant Salamander (Dicamptadon tenebrosus) and the Coastal Tailed Frog (Ascaphus truei) are ubiquitous while other stream-associated amphibians are present in various assemblages and lower densities (Welsh Jr. and Lind, 2002). Headwaters in the region are characterized by steep gradients, coarse substrate, significant amounts of woody debris and continuous riparian canopy (Corn and Bury, 1989). Amphibian assemblages are relatively stable in these undisturbed habitats, often displaying resilience to stochastic events that don't directly eliminate habitat (Welsh Jr. and Ollivier, 1998). When events such as tree removal during logging operations do occur, they have caused the extirpation of both facultative and obligate stream amphibians through destruction of microclimates and sedimentation of streams (Corn and Bury, 1989; Ashton et al., 2006). Stream amphibians are subject to relatively frequent local extinctions even in undisturbed habitat, relying heavily on juvenile dispersal to establish landscape connectivity between appropriate habitats. However, in fragmented landscapes, dispersal success is significantly diminished (Cushman, 2006). Even species capable of long-distance terrestrial movements, such as the Pacific Giant Salamander, may struggle to re-colonize streams post-disturbance if habitat connectivity is not maintained (Corn and Bury, 1989). 


\section{Riparian Systems}

\section{Riparian System Functions}

Riparian systems represent an important and often essential habitat for a diverse array for flora and fauna. One of the most biologically rich and complex ecological systems in the world, riparian communities consist of large and diverse tree stands that provide vegetated corridors for both aquatic and terrestrial animals (Naiman et al., 2000). Riparian vegetation is disproportionally valuable to bird species, especially during migration seasons (Knopf et al., 1988). In addition, freshwater and anadromous fish populations depend on the services provided by riparian vegetation, such as flow regime regulation, supplementation of in-stream cover (woody debris) and aquatic food-webs (allochthonous organic materials), as well as temperature regulation (Naiman et al., 2000; Pusey and Arthington, 2003; Booth, 2005). Other ecological functions influenced strongly by riparian areas include nitrogen exchanges through stream-related hyporheic flows, flood protection, and enhanced stream bank stability (Naiman et al., 2000; Pusey and Arthington, 2003; Ozawa and Yeakley, 2007)

\section{Riparian System Threats and Conservation}

Riparian areas, much like amphibians, are currently at risk from multiple threats. Historically, riparian corridors have been degraded from water management practices, livestock grazing, channelization and other anthropomorphic activities. The myriad of vertebrate species that benefit from disproportionate amounts of high- 
quality habitat in riparian areas, such as amphibians and avifauna, are largely ignored by riparian management directives that have traditionally focused on adjacent upland vegetation (Knopf et al., 1988). More recently, conservation of riparian systems has focused on particular resources (Wu et al., 2000), favoring charismatic species such as salmonids. However, localized restoration efforts are often insufficient to restore ecological structures and functions upon which resident fauna depend. Appropriate conservation of productive and complex riparian systems must take a cue from landscape ecology and manage on watershed scales to preserve associated faunal communities (Bond and Lake, 2003).

\section{Characterization of Riparian Systems in the Pacific Northwest}

In the Pacific Northwest region of the United States, many riparian systems are encompassed by the Pacific Coastal Rain Forest that extends from northern California to southern Alaska. These forest communities are primarily comprised of large, long-lived conifers such as redwoods, spruces and firs. Riparian areas composed of western hemlock (Tsuga heterophylla) and western red cedar (Thuja plicata) support significant populations of salmon, sturgeon and other prominent and culturally important aquatic organisms (Naiman et al., 2000; Pearson and Manuwal, 2001). This region was subject to intense silvicultural activities for much of the mid$20^{\text {th }}$ century, often resulting in the complete elimination of old-growth forest ecosystems and encouraging the prominence of successional Douglas-fir, red alder and big-leaf maple forest communities (Swanson and Franklin, 1992; Youngman, 
2002). However, due to federal legislation concerned with water quality issues, many riparian systems were maintained to prevent sedimentation and temperature elevations that might have impacted fish populations (Swanson and Franklin, 1992).

\section{Urbanization}

\section{General Impacts of Urbanization on Riparian Areas}

Currently, a majority of the world's population resides within urban centers (UN, 2008). Many of these urban centers are located near rivers, lakes or other significant sources of fresh water. The concentration of human populations next to water bodies leads to stresses being placed on the neighboring aquatic systems as water is withdrawn for uses such as the production of food and energy (Fitzhugh and Richter, 2004) and surrounding lands are increasingly developed. It is estimated that $41 \%$ of the world's population already live in river basins where water scarcity is a present and growing issue. With the world population expected to balloon to 9 billion people by 2050, urban centers will swell and water issues in these areas will intensify, further threatening already declining aquatic biodiversity via the continuing degradation of freshwater systems (Fitzhugh and Richter, 2004). Population growth also results in intensifying competition between land-uses, which is expected to result in increasingly small and fragmented forests in urbanizing areas (Alig and Plantinga, 2004). As a result, both facultative and obligate riparian species must compete for dwindling resources in urban areas where riparian habitat is reduced and degraded. 


\section{Landscape Development: Impacts to Aquatic Systems \& Amphibians}

Streams and their associated communities are extensively shaped by the landscapes through which they flow (Fausch et al., 2002). This intimate relationship translates development-related physical and chemical alterations of the surrounding landscapes directly to nearby aquatic systems. Impacts to streams in urbanized areas may include altered hydrology and stream channel morphology, raised stream water temperatures, altered stream water $\mathrm{pH}$, and decreased abundance and diversity of both vertebrate and invertebrate communities (Paul and Meyer, 2001; Booth, 2005). Heightened concentrations of pollutants in stream waters are also common within urban settings. Pollutants that appear in greater concentrations in association with urbanization include nutrients (such as nitrogen and phosphorus), chloride ions, pesticides, PCB's, PAH's and metals (Paul and Meyer, 2001).

Declines in stream-associated amphibian populations near cities have been tied specifically to densities of urban development (Riley et al. 2005). These declines correlate strongly with increased rates of sedimentation (Welsh Jr. and Ollivier, 1998; Price et al., 2011), lower amounts of available protective cover (Orser and Shure, 1972), increased peak stream flows (Riley et al., 2005), reduced base flows and general changes in water chemistry (Miller et al., 2007; Price et al, 2011). Impacts to water chemistry that have been demonstrated to affect amphibians include shifts in pH (Horne and Dunson, 1995), increased water conductivity (Miller et al., 2007), increased water temperatures and decreased dissolved oxygen content (Orser and Shure, 1972; Welsh Jr. and Ollivier, 1998). Declines have not been strongly 
correlated with agricultural land-use, though it has been suggested that pesticides transported from agricultural areas negatively affect amphibian populations (Davidson et al., 2001).

\section{Amphibian Conservation and Riparian Buffer Requirements}

The preservation of vegetated buffers around stream networks is often practiced to protect waterways and associated flora and fauna from the effects of development within the surrounding landscape. Though originally conceived to reduce the impacts of silviculture on salmon spawning habitats (Vesely and McComb, 2002), riparian buffer strips have been utilized for the conservation of many species in varied landscapes. However, the width and composition of riparian buffers required to provide adequate habitat and prevent harmful stream degradation is widely debated and species-dependant. Buffer widths of at least 45 meters were found to be essential for riparian-associated birds within managed forests in Washington State (Pearson and Manuwal, 2001), while riparian forest areas within 30 meters of streams was significant to aquatic invertebrate communities in urbanizing areas of Maryland but not agricultural areas (Moore and Palmer, 2005).

Being that all 47 amphibian species in the Pacific Northwest are riparian associates, stream buffer maintenance may prove an effective method of amphibian conservation in the region (Vesely and McComb, 2002). Studies aiming to define necessary buffer widths for amphibian conservation have often defined habitat ranges necessary to conserve the majority of amphibian populations, resulting in minimal 
buffer width requirements ranging from 6 to 76 meters (Olson et al., 2007).

However, sufficiently managing for a wide diversity of amphibians requires riparian buffers that adequately provide habitat for all amphibian life-stages as well as environments suitable for overwintering, feeding and nesting. Riparian buffers capable of encompassing these habitats as well as maintaining associated microclimates have been estimated to range from 160 to 300 meters (Semlitsch and Bodie, 2003; Perkins and Hunter, 2006; Olson et al., 2007). These past studies provide useful guiding principles for stream-associated amphibian conservation. However, effective management of amphibian communities must be specified to the environmental composition of particular regions and amphibian community assemblages.

\section{Urbanization of the Portland, OR and Clark County, WA Regions}

The population of the City of Portland grew by $10.9 \%$, from 523,000 to 580,000, within the last decade (City of Portland, 2004; Houck and Cody, 2011). With more than 1.6 million people currently living in the Portland-Vancouver tricounty area (Houck and Cody, 2011), the population within what has recently been termed the 'Portland-Vancouver Intertwine' (The Intertwine Alliance, 2012) region will inevitably swell as the Pacific Northwest continues to grow quickly along with the rest of the west coast. In parallel fashion, the more-than 14,000 hectares of impervious surface within the city of Portland (City of Portland, 2004) and 5000 hectares in the city of Vancouver (AMEC Environment and Infrastructure, 2011) will 
likely expand with increasing populations. The conservation of natural areas will depend largely on the effectiveness of regional planning strategies such as Portland's 'Nature of 2040’ management proposal (Metro, 2000).

\section{Riparian Refugia and Amphibian Communities in the Portland-Vancouver Region}

\section{Portland Streams \& Riparian Areas}

Streams and associated riparian systems in the Portland metropolitan region have been subject to significant alterations due to the growth of the city. Unaltered riparian areas within the larger Portland area historically consisted of stands of Douglas-fir (Pseudotsuga menziesii), Ponderosa pine (Pinus ponderosa) and Oregon white oak (Quercus garryana) with larger waterways also composed of significant stands of Black cottonwood (Populus trichocarpa) (Lev and Sharp, 1991; Poracsky, 1991). Modern riparian areas have shifted to a largely deciduous-based canopy comprised of Oregon ash (Fraxinus latifolia), red alder (Alnus rubra), willows (Salix species) and remnant cottonwoods (Hennings and Edge, 2003). Riparian communities in urbanized areas within the region have also experienced an influx of non-native species. Though overall species richness of riparian plant communities in urban areas has increased compared to that of rural riparian areas, this increase is largely due to the spread of exotic species such as Himalayan blackberry and reed canarygrass (Youngman, 2002). 
Riparian systems within the Portland-Vancouver region have also experienced many direct, physical alterations. In the past 150 years, the length of streams flowing through the Portland region has been reduced from $766 \mathrm{~km}$ to $418 \mathrm{~km}$ through construction-related activities such as paving, culverting and filling (City of Portland, 2004). Clearing of riparian vegetation has also occurred on large scales both historically and in recent decades. Between 1990 and 2002, Hillsboro, Oregon City and Portland lost a combined 14.3 hectares of unmanaged riparian vegetation within a 7.5 meter buffer of all their local streams. Within 100 meters of streams, those cities lost approximately 350 hectares of riparian vegetation over the same time period, representing a $10 \%$ loss of the total riparian vegetation for that buffer width (Ozawa and Yeakley, 2007).

Despite recent losses, riparian areas in the Portland-Vancouver metropolitan region are protected by a growing number of policies and regulations. Prompted by the 1973 Oregon state land-use law establishing the Land Conservation and Development Commission (LCDC), each major city in Oregon was required to establish land-use regulations protecting urban natural resources. This movement resulted in a diverse set of policies controlling development in riparian areas that include regulated floodplain districts (City of Hillsboro), establishing single-purpose overlay districts (Oregon City) and stream setback regulations (City of Portland) (Ozawa and Yeakley, 2007). Vancouver has several similarly purposed policies including the Shoreline Management Program (SMP), which explicitly protects 
riparian areas that support wildlife as well as geologic, hydrologic and biologic services (City of Vancouver, 2007).

\section{Amphibians in the Portland, OR Region}

There are 47 amphibian species known to inhabit the Pacific Northwest region, one-third of which are obligate-stream species, requiring stream habitat for at least one portion of their life-cycle. A quarter of the amphibian species in the Pacific Northwest are specifically dependent on headwater stream systems for a period of their lifecycle (Olson et al., 2007). Of those species, 16 have ranges that extend into the greater Portland, OR and Clark County, WA regions. Four of these species represent stream-obligate amphibians (the Pacific Giant Salamander (Dicamptadon tenebrosus), the Cope's Giant Salamander (Dicamptadon copeii), the Cascade Torrent Salamander (Rhyacotriton cascadae) and the Coastal Tailed Frog (Acsaphus truei). Facultative stream species consist of seven salamander species, four frog species and one toad species (Jones et al., 2005; Bartlett and Bartlett, 2009). Refer to Appendix B for a complete list of species that have ranges within the study area.

Though in-depth scientific studies on amphibians within the PortlandVancouver region are few, there have been a number of surveys conducted in recent years with the aim of identifying species present in the region. A study by Katie Holzer (2009a) with the City of Portland Bureau of Parks and Recreation observed amphibian populations within the Oaks Bottom Wildlife Refuge. With a focus on pond-breeding species, this study recorded the presence of the Pacific Tree Frog 
(Pseudacris regilla), the Northern Red-legged Frog (Rana aurora) and the Western Long-toed Salamander (Ambystoma macrodactylum macrodactylum) as well as two terrestrial species (the Oregon Ensatina (Ensatina eschscholtzii oregonensis); the Western Red-backed Salamander (Plethadon vehiculum)). Another study by Holzer (2009b) searched the Tryon Creek, Columbia Slough, Johnson Creek and Willamette Watershed areas. This survey identified five additional species as present in the region (the Dunn's Salamander (Plethadon dunni), the Northwestern Salamander (Ambystoma gracile), the Rough-skinned Newt (Taricha granulosa granulosa), the Bullfrog (Rana catesbeiana) and the Pacific Giant Salamander). Though these studies suggested relationships between environmental variables and most of the species observed, stream-associated amphibians were only anecdotally noted as occurring in Forest Park.

Other recent studies that have accounted for amphibians around Portland include an assessment of amphibian habitat in Errol Heights (Corkran, 2005), an Environmental Foundation Study of West Hayden Island (Entrix, Inc. 2010) and an Environmental Assessment prepared by the City of Portland (2004). A Master's thesis completed in 2005 by Laura Roberts surveyed terrestrial amphibians in greenspaces around the Portland metropolitan area (Roberts, 2005). In addition, there are currently a number of amphibian monitoring programs within the Portland, OR region sponsored by Metro and the City of Portland that focus on pond-breeding populations. However, few efforts to characterize stream amphibian presence in the 
Portland metropolitan region have been conducted and efforts that have occurred are in unofficial formats such as the Forest Park BioBlitz (City of Portland, 2012).

\section{Potential Habitat for Lotic Amphibians in the Portland-Vancouver Region}

Despite a rapidly growing population and associated increases in construction, a wealth of forested riparian refugia still exists within the confines of the PortlandVancouver metropolitan area, as shown in Figure 1. Over 8,100 hectares of natural area are maintained within 460 parks (Ozawa and Yeakley, 2007; The Intertwine Alliance, 2012), many of which encompass stream networks (e.g. Fanno Creek Park, Forest Park, Tryon Creek State Natural Area). Many more natural riparian areas remain outside the confines of parks, preserved by private landowners due to development-restricting regulations or personal affinities for nature. However, the state of many of these riparian areas and the streams they encircle is largely undocumented and unmonitored. As a result, the ability of riparian areas within the Portland-Vancouver metropolitan area to provide adequate habitat for streamassociated amphibian populations is presently unclear. 


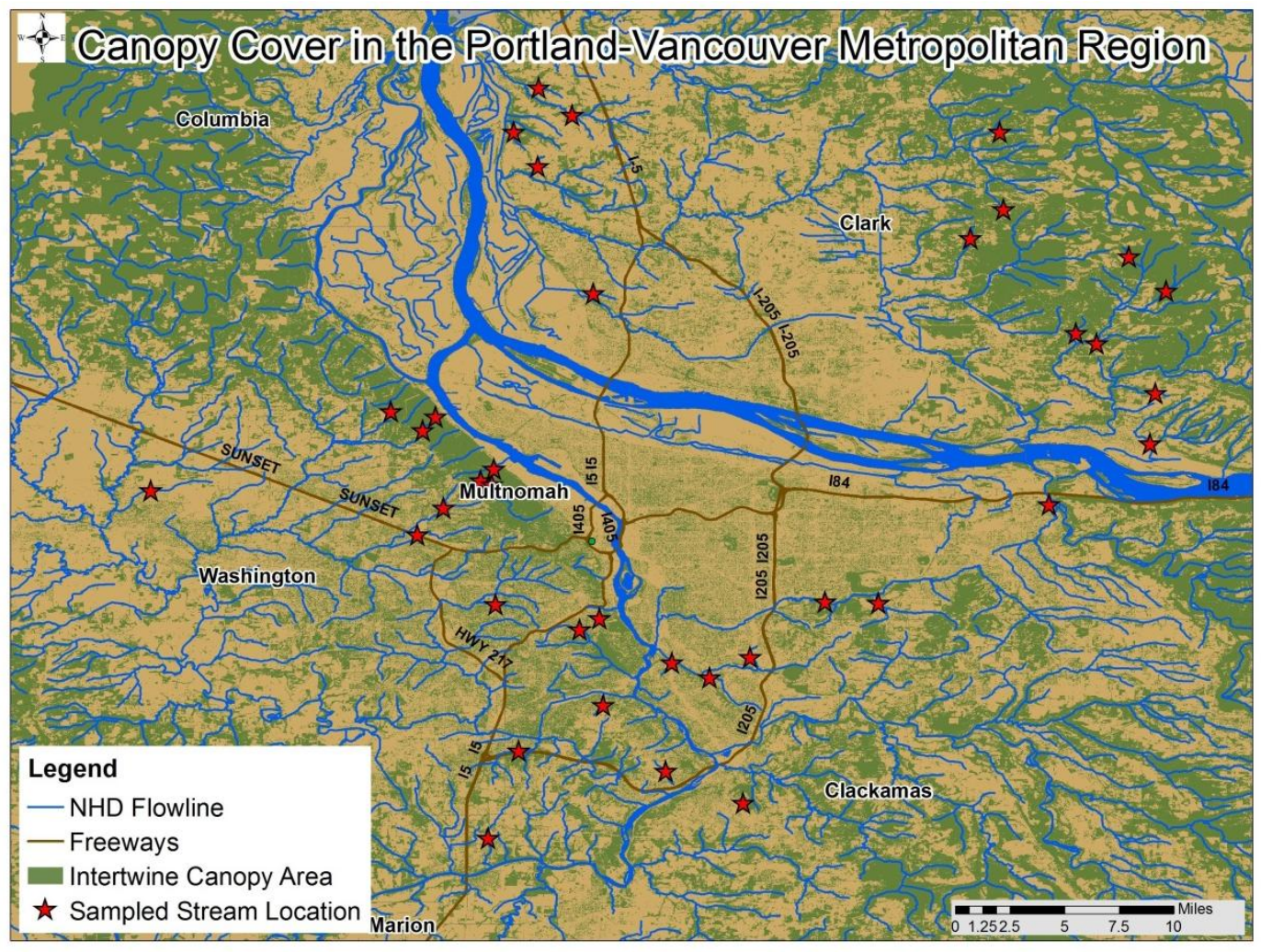

Figure 1 - Canopy Cover in the Portland-Vancouver Metropolitan Area. This map shows the areas of canopy and stream networks present throughout the Portland-Vancouver region. Canopy, represented in green, is denser outside of the urban areas and densest in Forest Park and north through Columbia County as well as throughout the eastern side of Clark County. Stream networks have been largely eliminated from areas in Multnomah County as well as the southwest portion of Clark County. 


\section{OBJECTIVES AND HYPOTHESES}

Efforts to fulfill research needs associated with amphibian conservation must focus on two somewhat divergent paths. First, there is a need for studies that might distinguish direct causes of decline from indirect ones (Carey et al. 2001). Secondly, large, multi-scale empirical field studies must assist in uncovering the effects of landscape-scale processes such as habitat loss and fragmentation (Cushman, 2006). Linking observed patterns and underlying processes should be done with caution and confirmed through field and laboratory tests (Cale et al., 1989; Davidson et al., 2001). Large-scale field studies may effectively serve to identify areas in which to investigate direct causes of decline.

The purpose of this study was to identify refugia inhabited by lotic amphibians within the Portland-Vancouver metropolitan region as well as to characterize the physical habitat in these refugia. This study also sought to identify correlations between environmental variables affected by human landscape development and amphibian presence/absence in an effort to identify characteristics of refugia which might influence stream-associated amphibian occupancy of streams within the region.

This study tests the following hypotheses:

1. Stream-associated amphibian communities will occur in lower abundances and be less diverse with increasing amounts of human development in the surrounding landscape. Landscape variables associated with urban 
development (such as the increased presence of impervious surfaces and high-density structures) will correlate more strongly with decreasing stream amphibian abundances and diversity than variables associated with less intensive forms of development (such as agriculture).

2. Stream-obligate species abundances and diversities will be more negatively correlated with development-associated alterations to stream conditions than stream-facultative species.

3. Stream-amphibian refugia will have lower water temperature, lower water conductivity, higher ratios of coarse substrate, greater canopy density and greater areas of adjacent forested habitat than stream habitats without amphibians. 


\section{METHODS}

\section{Research Approach}

To characterize lotic stream amphibian populations and the conditions of streams throughout the sample region, methods were established to randomly select streams within the Portland-Vancouver region. In addition, methods were used to characterize the environment surrounding sampled streams at various spatial scales, measuring factors that may be affected by development in the surrounding landscape to ascertain how regional streams are being altered by landscape fragmentation. Microhabitat variables were collected during one-time site visits for each stream segment. Meso-habitat and land-use variables were gathered with remote-sensing technologies, with land-use variables measured at different riparian buffer widths to determine the importance of landscape patterns at different scales. Lastly, statistical methodologies were used to determine which environmental variables influenced stream amphibian presence or absence within sampled stream segments and to further discover which variables and spatial scales were most influential on amphibian populations.

\section{Site Selection}

Site selection was conducted and randomized utilizing GIS layers available for the Portland metropolitan area and Clark County WA regions. Sites were required to meet minimal habitat requirements for stream amphibians, including appropriate in-stream and stream-side habitat. Random selection of streams that met habitat 
requirements was conducted to represent the full range of environmental conditions within forested riparian refugia in the Portland-Vancouver metropolitan region.

\section{Preliminary Habitat Requirements for Site Selection}

To test the hypotheses, only streams that represented potentially adequate stream-obligate amphibian habitat within an urban or urbanizing landscape were selected. These streams were first, second or third order streams (as defined by Strahler's ordering technique; Allan and Castillo, 2007) to assure relatively low volumes of discharge that make active methods of amphibian sampling in stream transects feasible. Headwater streams were also selected to minimize potential exclusion of aquatic amphibians by larger fish species. In addition, selected stream segments (segments being the unit of definition within the USGS NHD geodatabase) provided basic habitat requirements including consistent perennial stream flow for larvae and potentially sufficient forested stream-side habitat for juveniles and adults. Streams with forested riparian buffers of at least 10 meters in width were targeted.

Streams were analyzed using the Arc Geographic Information Systems (ArcGIS) program and the National Hydrologic Dataset geodatabase (as compiled by the US Geologic Survey). Additional GIS layers utilized during analysis consisted of data from the Metro Resource Data Center (including layers for taxlot, county and city lines, land cover, streets), the City of Portland (Portland Aerial Photos from 2002), the City of Vancouver (Orthophotos from 2009) and the USGS RLIS dataset (including layers of vegetation, township boundaries, contours and slopes). 


\section{Site Selection through ArcGIS Analysis}

Stream layers for the areas of the Portland Metropolitan region and Clark County, Washington, were acquired from the National Hydrologic Dataset (NHD) available from the USGS (nhd.usgs.gov) (Figure 1). Streams represented by the NHD Flowline data layer were evaluated for flow frequency and stream order. NHD Flowline layers were clipped to the appropriate area (via the Urban Growth Boundary borders for Portland-metropolitan area cities as well as the Clark County border) to ease analysis and data processing time. Using the stream definitions available under the attribute field 'FCode', flowlines defined as 'Stream/River: Hydrographic Category $=$ Perennial' were selected and exported to a new stream layer, excluding annual, ephemeral and artificial waterways from further analysis. This newly created layer was used to classify stream order.

As stream order was not readily defined within the NHD layers, this attribute was delineated manually using the Strahler's ordering technique at a scale of 1:24,000. To define stream order, the newly created layer of perennial streams was superimposed on the original NHD Flowline layer. A new field titled 'Stream Order' was added to the perennial stream layer. Activating the 'Editor' function within ArcGIS, streams within the perennial layer were systematically selected and assigned an order. All lines from the NHD Flowline layer were considered when defining stream order to recognize perennial streams that have smaller, impermanent upstream channels or historical upstream confluences that may have been piped or channeled. In other words, an effort was made to determine stream order as it would have been 
defined if the watersheds were observed in a historical, unaltered state. Stream orders were color-coded using the 'Symbology' function and streams were defined by working from first-order streams downward to minimize error. Once stream order had been defined for all perennial streams, headwater streams (termed here as first, second and third order streams) were selected and exported to a new layer.

Stream segments were further narrowed down by two additional criteria: segment length and adjacent canopy cover. As riparian vegetation was a prerequisite for site selection, the Metro 2007 High Resolution Land Cover dataset was used to determine if 'High-Structure Vegetation', or an existent canopy layer, was present adjacent to the stream. Stream segments with adjacent high-structure vegetation were exported to a new layer. The streams in Clark County, Washington, were not narrowed using this criterion due to the lack of a comparable dataset, though adjacent vegetation was assessed during the site-ownership determination utilizing aerial photographs. Finally, stream segments were selected based on having a total length (as defined in the 'LengthKM' attribute field) greater than $0.1 \mathrm{~km}$, or 100 meters. This criterion was established to ensure that a 50 meter transect could be established within a single stream segment while maintaining a buffer between the transect itself and a confluence with another stream or another barrier (represented by a node defining the ends of a stream segment unit). Streams meeting the minimum length requirement were again exported to a new layer.

To randomize the selection process during further analysis and final site selection, a 'Random_Value' field was created within the attribute table of the 
selected stream segments. Random numbers were generated in excel using the RAND function in a number of cells corresponding to the number of selected segments. Values were then copied and pasted into the attribute table. Stream segments were sorted in ascending order according to their assigned random value.

\section{Site Ownership and Access Determination}

Subsequent to the selection of stream segments meeting basic appropriate habitat criteria, ownership and vegetation of land surrounding each selected stream segment were mapped, listed and analyzed. Adhering to the randomization technique described earlier, stream segments were observed in numerical order according to the 'Random_Value' field.

Riparian vegetation was observed for each potential site in two ways. First, if adequate canopy cover existed along the stream segment, it was defined as a viable site in a created attribute field entitled 'Site_Viability'. Adequate canopy cover was defined as a contiguous riparian forest of at least 50 meters length (measured parallel to the stream channel) and 7.5 meters width (perpendicular to the stream channel). Aerial orthophotos were utilized for this analysis (the 'February 2002 Missions True Color' layers was used to analyze streams in the Portland area and the 'WA09 Orthophotos' was used for Clark County streams) and the 'Measure' tool was used to estimate riparian buffer lengths and widths. If adequate vegetation appeared to be present adjacent to the stream segment, a tax-lot layer was applied over the orthophoto to determine if enough of the riparian area occurred within one or two 
adjacent tax-lots to establish the required 50 meter transect within that stream section. Tax-lots containing smaller segments of stream-length were avoided due to the difficulties and low likelihood of obtaining access-permission from multiple, independent adjacent landowners.

An excel database of tax-lot information was created. Tax-lots were listed according to stream segment with the following information: FID Number (an ArcGIS identifier field), stream order, waterway name, tax-lot owner name, tax-lot address, owner mailing address, presence/absence of other sampleable tax-lots along the stream segment, nearest park or roadway, tax-lot FID and additional notes. Fields were also created to indicate if an owner had been contacted, permission to sample had been acquired and if a site was sampled and on what date it was sampled.

Once an adequate number of stream-side tax-lots had been identified, an attempt was made to contact the associated land owners. No priority was assigned to either public or private lands during site selection. For private land owners, mailings were prepared which included a brief letter requesting permission to access the stream located within the owner's property and a pre-stamped postcard with which to respond. See Appendix $C$ for an example of the permission letter and response postcard. For public land owners, contact information was sought through websites, identifying resource managers for the appropriate agency and contacting them to acquire access permission.

Once responses were received, either through mail or direct contact, a list of stream segments with 'access permission' was compiled. Visits to each stream were 
scheduled (through continuing communication with the owner, if requested). To

maintain the independence of stream sites, only one site per same stream channel was sampled with the exception of Johnson Creek and Kelley Creek. This exception was

allowed because these two stream segments are spatially separated by $3.6 \mathrm{~km}$ of stream channel and are subsequently located in separate Hydrologic Unit Classes (level 12) (Figure 2).

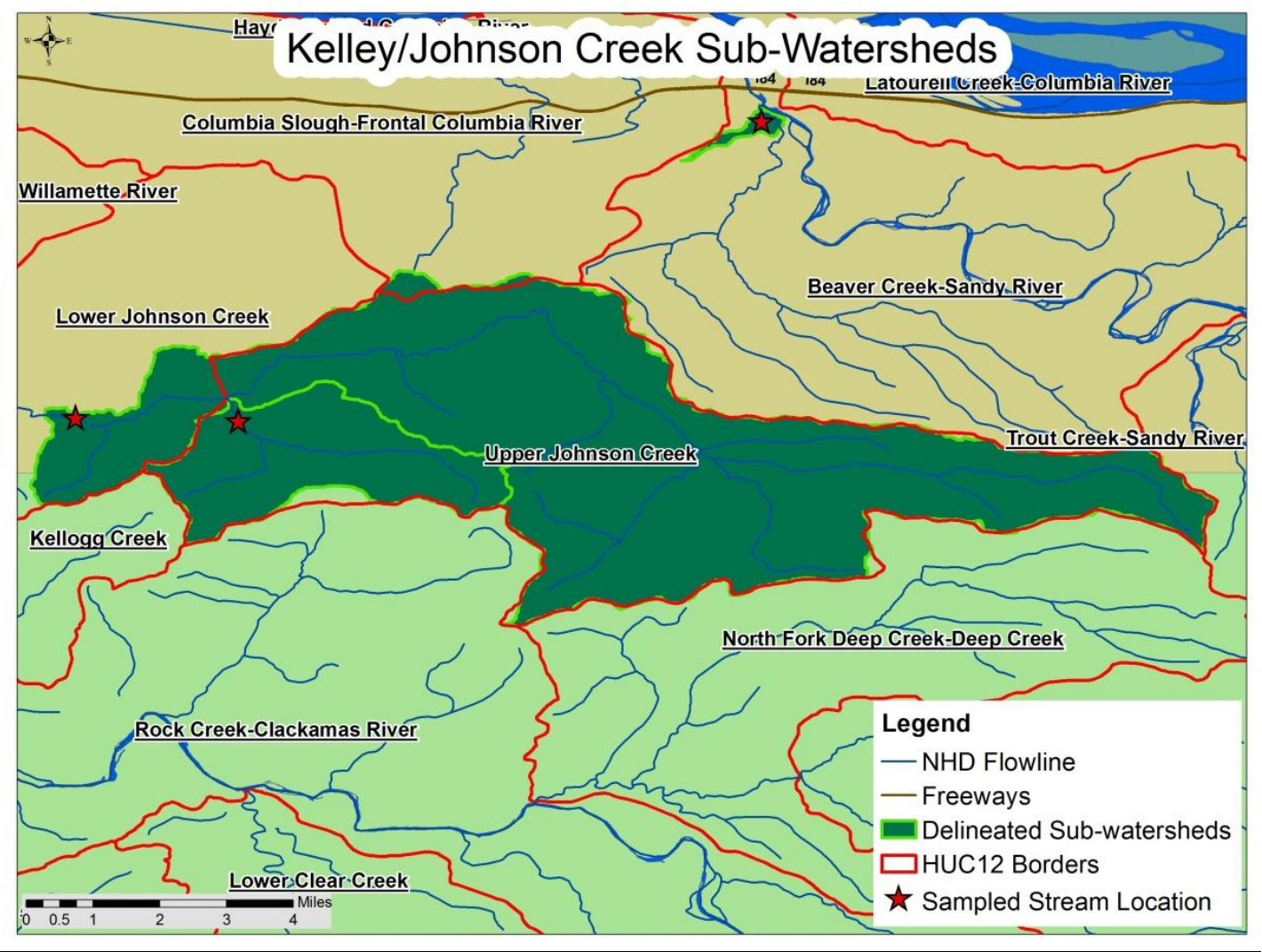

Figure 2 - Kelley and Johnson Creek Sub-Watershed Map. This map depicts the overlapping subwatersheds of Kelley Creek and Johnson Creek. These stream sites are separated by approximately 3.6 $\mathrm{km}$ of stream. In addition, they are located in different Hydrologic Unit Class (HUC) 12 units (as shown with the red HUC12 borders) with the Kelley Creek site being located in the Upper Johnson Creek unit and the Johnson Creek site located within the Lower Johnson Creek unit. Because of these factors, both sites were sampled despite their interdependence. 


\section{Transect Establishment and In-Situ Field Sampling}

In situ measurements were utilized to characterize the condition of the stream and riparian area at each site. In addition, amphibian surveys sought to establish the presence of resident facultative and obligate stream species. Though water temperature and conductivity can be extremely variable, often fluctuating seasonally as well as shifting dramatically during precipitation events, it was assumed that sampling during the summer when streams are generally at base-flow would mitigate for these temporal fluctuations in stream water chemistry. Amphibian populations were surveyed with active-search methods during the day, being surveyed from early morning to mid-afternoon. Surveys were conducted along a 30-meter section of stream and incorporated a meter of bank-side habitat on both sides of each stream. A meter of bank habitat is not sufficient to assess the entirety of resident facultative stream amphibian populations. However, facultative amphibian captures have been shown to be highest within the first five meters of the bank (Kluber et al., 2008). In addition, amphibian surveys were often limited by property boundaries and thick streamside vegetation, making more extensive terrestrial surveys impractical. All surveys took place during the summer of 2011, between June $21^{\text {st }}$ and September $21^{\text {st }}$, when there was little precipitation and low stream levels may concentrate amphibian populations in streams (Stoddard and Hayes, 2005). Stream survey methodology was adapted from those used by Corn and Bury (1989) and Grant et al. (2009). 


\section{Transect Establishment}

Stream transect locations were determined based on several factors: property access limitations, presence of riparian forest and interruptions in stream-flow (such as that caused by a culvert). First, it was determined what section of the stream was accessible according to the boundaries defining the property or adjacent properties where permission was obtained to enter. With that established, interruptions in riparian vegetation and/or the stream channel were avoided by placing the beginning of each transect at least 10 meters upstream or downstream of the interruption. A measuring tape was laid in the stream channel, following the meander of the channel, for 50 meters with each 10 meter and the 25 meter mark being noted with a flag. Within the 50 meter transect, vegetation samples were obtained from the 0 meter, 25 meter and 50 meter points. Amphibian sampling occurred between the 10 meter and 40 meter mark, surveying in three 10-meter increments (10-20 meters, 20-30 meters and 30-40 meters). Refer to Figure 3 for a schematic of the stream transects established.

In a few instances, sampling the stream section identified through remote sensing analysis was not feasible due to unforeseen difficulties. When necessary, the sampled section of the stream was moved to another channel within the immediate stream network. A list of the sites at which this occurred and the reasoning behind the site shift can be found in Appendix D. 
Vegetation Sampling

Riparian vegetation was assessed using a transect technique. Three transects were established at each site, extending for at least 5 meters and at maximum 60 meters out perpendicular from the stream channel along one bank. Vegetation transects were established at the 0 meter, 25 meter and 50 meter marks of the stream transect (Figure 3). If any indications were found that the riparian vegetation had been actively managed along the stream transect, vegetation sampling was not performed at that site. These areas were avoided due to a desire to sample only areas with naturally occurring plant communities. Signs of active management included freshly-cut vegetation, indications of herbicide spraying and recently planted vegetation. In addition, if either a large physical barrier or extremely steep terrain (exceeding a $45^{\circ}$ slope) were encountered along a transect, sampling ceased before the end of the riparian forest or 60 meter mark.

\section{Stream Sampling}

Environmental variables were collected at each site to assess the physical characteristics of the stream within the transect area. Water temperature and conductivity were measured at the 0 meter mark, or the downstream end, of each stream transect with a YSI meter. Canopy cover was estimated using a densiometer at the mid-channel point at the 10, 20, 30 and 40 meter marks (Figure 3). Habitat within each stream transect was categorized into one of three types of meso-habitats: riffle, run and pool. The stream meso-habitat was measured by characterizing the 
dominant structures of the stream for each half-meter of stream channel within each transect.

Stream substrate was estimated as percentages of substrate size-classes within transects running perpendicular to the stream channel. Substrate size classes included silt (particle size $<.0625 \mathrm{~mm})$, Sand/Gravel $(.0625-4 \mathrm{~mm})$, Pebbles $(4-32 \mathrm{~mm})$, Cobble $(32-256 \mathrm{~mm})$, Boulder (> 256mm), Bedrock (continuous rock material) and Organic Matter (leaf litter and woody debris). These substrate classes were modified slightly from those defined as the Wentworth classification so that all cover capable of completely concealing an amphibian was included in the 'Cobble' category (Cummins, 1962). Substrate composition was visually estimated for a transect running across sections representing each type of meso-habitat within each 10-meter sampling section, totaling up to nine substrate transects per 30 -meter stream segment (Figure 3). Working in an upstream direction, the first stream segment of a particular type of meso-habitat was selected for measurement. For the purposes of further analysis, substrate types were simplified into three classes according to the average particle size. Silt and sand substrates (0-4 mm particles) were classified as 'fine' substrate, while gravel, pebbles, cobble and boulders were classified as 'coarse' substrate (particles larger than $4 \mathrm{~mm}$ in diameter). Bedrock represented the final grouping for substrate. Depth measurements were also taken to estimate the maximum depth of pool meso-habitats in each 10-meter subsection. If a particular meso-habitat did not exist in a 10-meter subsection, substrate and depth measurements for that meso-habitat were omitted from measurement. 
The number of cover objects lifted in each transect was tallied and averaged between the different observers to account for differences in thoroughness and opinion as to what is considered adequate cover. Air temperature was recorded at the start of the sampling period along with a general classification of the weather. The presence of fish and crayfish was noted for each site as well. In addition to the above measurements, notes were taken to record any interesting or relevant qualities of the stream or surrounding environment. These notes included information on the presence of trash, the location and distance to trails and/or culverts that interrupted the stream channel, evidence of human alteration/management of the area surrounding the transect, and any background information about the stream provided by property owners.

\section{$\underline{\text { Amphibian Sampling }}$}

Amphibians were sampled along each stream transect using an active cover search (ACS) method with temporary removal. Active dip-netting involved the lifting of any cover object large enough to conceal an amphibian and sweeping underneath with a net. Amphibians that were observed but not caught were pursued until caught or until it was reasonable to assume the individual would not be found. Captured amphibians were placed in a small zip-lock bag (filled with adequate water and air) and removed from the stream channel until the sampling session concluded to avoid duplicate observations. Using bags to temporarily store salamanders reduced direct handling of amphibians, minimizing potential stress and dehydration. 


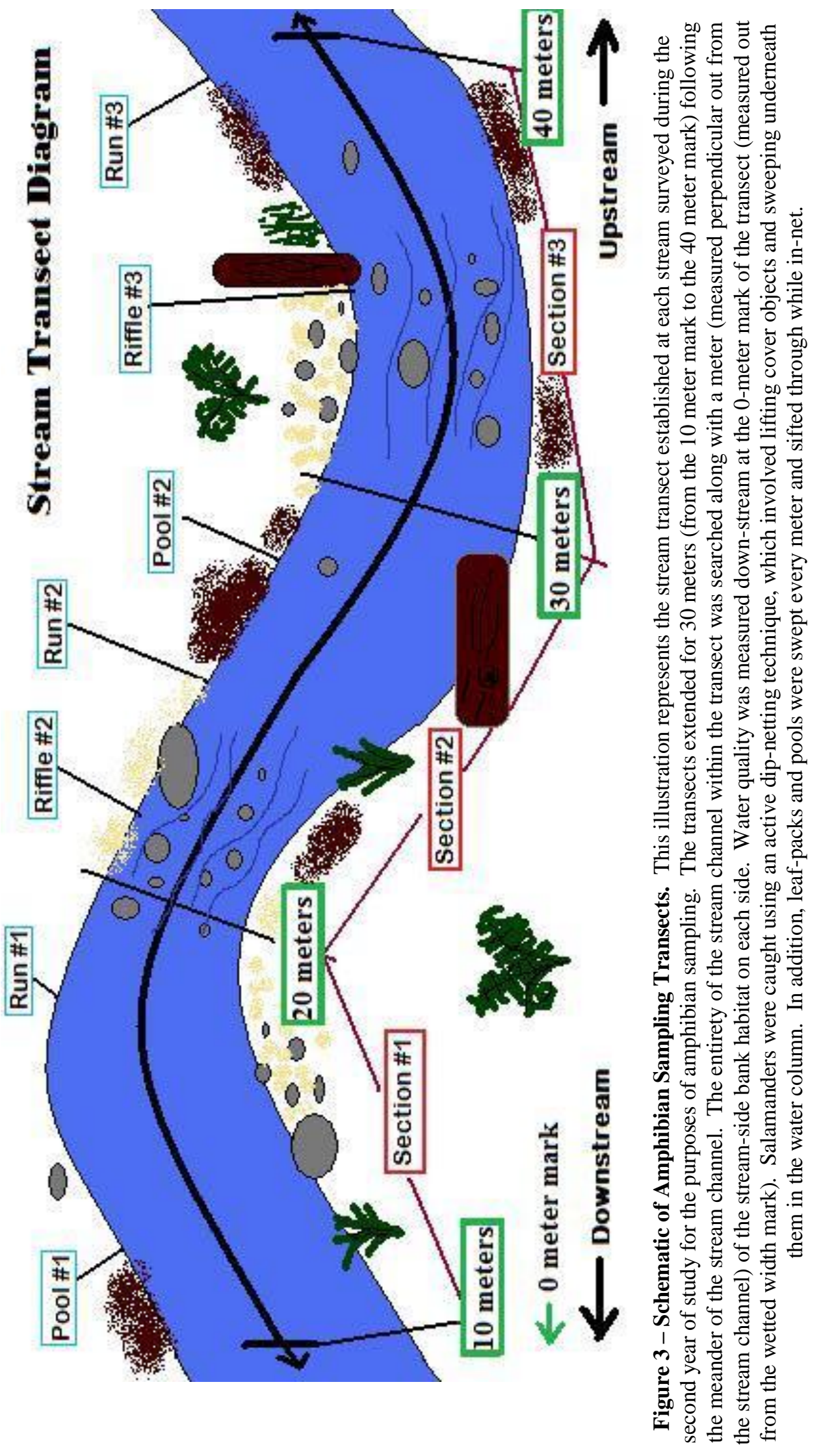


Sampling sessions consisted of three passes in each subsection conducted by three independent observers. Each individual sampling for amphibians covered one transect per pass. Unit effort values during sampling sessions were recorded as cover objects lifted along with a measurement of total time spent searching. Captured amphibians were recorded for species, life stage (larvae, juvenile, or adult), length (total and snout-vent), weight and the type of cover they were found in or under (Grant et al., 2009).

\section{Biogeographic Parameter Sampling Via Spatial Analyses}

Biogeographic variables were collected to represent conditions at various spatial scales. GIS analysis was used to define land-use variables at various distances from the upstream stream network in an attempt to categorize land-use in the subwatersheds surrounding each site. In addition, proximity to roads, size and shape of surrounding forest areas and impervious surfaces in the surrounding landscape were measured to account for biogeographic factors resulting in habitat fragmentation and stream degredation.

\section{Determination of Site Location}

To conduct further analysis via remote sensing utilizing the ArcGIS program, sites first needed to be mapped more accurately than was first required for site selection. Utilizing road layers and aerial photography available for the Portland metropolitan area and Clark County, Washington, the stream segments selected from 
the NHD Flowline dataset were clipped. All stream polylines were clipped to $200 \mathrm{~m}$ or shorter segments containing the sampled stream transect. Once clipped, these stream segments were exported to a new layer (Sampled_Streams_CC for Clark County and Sampled_Streams_Final for Portland area streams).

\section{$\underline{\text { Stream-Reach Variable Collection }}$}

Environmental variables collected at the stream-reach scale include surrounding land-use (within a 500m range), proximity to a road crossing (both upstream and downstream) and forested patch size (area and perimeter).

\section{Surrounding Land-use}

To define the surrounding land-use within 500 meters of each stream segment, a buffer was defined around each stream segment to that distance. Once buffers were created for each set of stream segments (one for the Portland metro area and another for Clark County sites), the 500 meter buffer layers were joined using the 'Union' function. Attribute tables were simplified to ensure that only site-names were listed. The united buffer layer was then manipulated utilizing the 'Identity' function to associate each buffer with the appropriate sampled site, defined now in the new layer's attribute table. Lastly, the 'Identity' tool was again used to identify the landuse polygons from the appropriate land-use layers. This resulted in a final layer comprised of a mosaic of land-use polygons within the borders of each buffer. The attribute table for this layer, comprising primarily of the site names and the grid-code 
and area of the contained land-use polygons, was exported for further sorting and analysis.

Two separate land-use layers were used during analysis: the NLCD 2006 dataset, with a resolution of 30 X 30 meters, and a LIDAR-derived landuse dataset created by Theresa Burcsu and associates at the Institute for Natural Resources (INR), which had a resolution of 5 X 5 meters (available by request from http://oregonstate.edu/inr/). Each land-use dataset was processed prior to the Identification methodology described above. Both datasets were first converted from rasters to polygons to ease calculations relating these layers to site-associated buffer polygons. In addition, each dataset was 'dissolved' by its grid-code attribute (which represented different land-use types) to simplify and abbreviate the attribute tables from the resultant Identified buffer layer. Defining the surrounding land-use out to a distance of 500 meters was chosen in relation to the maximum dispersal distances of the amphibian species that were observed during the in-situ sampling period (See Table 2 for a list of dispersal distances for observed amphibian species). 
Table 1 - Maximum Distance Traveled by Observed Amphibian Species. This table represents the maximum recorded dispersal distances by the species encountered during field surveys conducted for this study. Source: Lannoo, 2005.

\begin{tabular}{|l|l|l|}
\hline \multicolumn{1}{|c|}{ Amphibian Species } & Maximum Dispersal Distance & \multicolumn{1}{c|}{ Dispersal Reason } \\
\hline Dicamptadon tenebrosus & $400+$ meters & Post-metamorphic Migration \\
\hline Rhyacotriton cascadae & $\begin{array}{l}\text { Unknown, larval movement of 22 } \\
\text { meters downstream }\end{array}$ & N/A; Little Movement \\
\hline Plethadon vehiculum & $\begin{array}{l}\text { Unknown, Home-ranges of a few } \\
\text { meters }\end{array}$ & N/A; Little Movement \\
\hline $\begin{array}{l}\text { Plethadon dunni } \\
\text { granicha granulosa }\end{array}$ & Unknown, Small home-ranges & N/A; Little Movement \\
\hline Rana aurora & $500+$ meters & Mating Migration \\
\hline Pseudacris regilla & 238 meters & Post-metamorphic Migration \\
\hline
\end{tabular}

Proximity to Road Crossing

The proximity of each sampled stream segment to a road crossing was measured using the basic measuring tool available in ArcGIS. Stream segment polylines were overlaid on top of the NHD Flowline dataset used for site selection. In addition, road/street layers available for the greater Portland region and Clark County, Washington, were added to the map as well. Distance measurements were started at either end of the defined sampled segment and traced the NHD flowline layer until an intersection with a road was reached. Road and stream locations were confirmed via comparisons with aerial orthophotography.

Distances from the sampled stream segment to a road crossing were estimated both upstream and downstream from each transect. In some cases, no value was acquired for the distance upstream due to the absence of a road crossing prior to the 
genesis of the stream channel. Due to the presence of these null values, distances upstream to the nearest road crossing were omitted from further statistical analyses.

\section{Forested Patch Size Delineation}

The area and perimeter of forested patches adjacent to each site were calculated utilizing the LIDAR-derived land-use dataset. A forested patch was considered an uninterrupted area of canopy. To represent the gross area of canopy in the regions surrounding all sampled sites, a layer of polygons representing Conifer and Hardwood 'land-uses' was exported from the original LIDAR land-use dataset.

As roads were considered an interruption in a contiguous forest patch for these analyses, a polygon layer was defined around each sampled stream segment (or group of segments where appropriate) by tracing the road network such that a continuous border was formed along the roads surrounding each site. All paved roads and smaller roads with names (such as major logging roads in Clark County) were included in this exercise. Driveways and smaller, unnamed dirt roads were omitted from consideration. The canopy layer from the LIDAR land-use dataset was then clipped by these road-defined polygons, eliminating canopy areas outside of the roadenclosed polygons.

Next, canopy polygons were selected based on their adjacency to the sampled stream segment. Selection was extended outwards from the site based on the adjacency of each subsequent canopy polygon to the border of an already selected canopy polygon. This method was used to define and export the contiguous canopy 
layers adjacent to each site. The resulting canopy layer was dissolved and then identified by sampled stream segment name to create a layer of unified canopy polygons around each site.

Many of these canopy polygons required further editing due to the inclusion of polygons with non-adjacent sections and intersecting roads that were not included in the road-defined border from earlier analysis. Each canopy polygon was 'exploded' and clipped to eliminate non-adjacent or catty-corner polygons as well as sections of canopy that were separated from the larger contiguous polygon by roadways tangential to the original road-defined border. Once properly edited and confirmed (via comparison to orthophotography available for each region), the attribute table for the finalized canopy layer was exported for further analysis.

\section{$\underline{\text { Sub-watershed Variable Collection }}$}

Land-Use and Impervious Surface Area were analyzed and calculated for the sub-watersheds defined for each stream segment.

\section{Sub-Watershed Delineation}

The ArcHydro toolset available in ArcGIS was utilized to define the subwatersheds of each stream site. Digital Elevation Models (DEMs) were acquired for the Portland metropolitan and Clark County, WA, regions; each DEM utilized had a resolution of 10 X 10 meters. Defining the sub-watershed for each site utilizing DEMs was desirable due to the inaccuracies noted in the sub-watersheds defined by 
the NHDPlus datasets available through the USGS. While generally accurate, these databases proved to be inaccurate in mapping a few key sites, notably a few of the sampled stream sites within Forest Park which were included erroneously in a watershed defined on the West slopes opposite of Forest Park. In addition, the Mill Creek watershed proved to be grossly inaccurate according to stream definitions provided within the NHDPlus dataset. Observations of inaccuracies were confirmed using the DEM datasets as well as aerial orthophotography of each region. Utilizing DEM layers to define watersheds for each region allowed sub-watershed definitions that corrected for these inaccuracies.

To define the watersheds, a Flow Direction raster (FDR) was created using the 'Flow Direction' tool within the Terrain Preprocessing menu of ArcHydro. To eliminate potential errors in watershed processing, the DEM was evaluated for sinks (using the 'Sink Evaluation' tool) and sinks were subsequently filled using the 'Fill Sinks' tool prior to the creation of the FDR. The resulting FDR was processed using the 'Flow Accumulation' tool to create a Flow Accumulation raster (FAC). A stream network was delineated using the created FAC from each of the regions concerned (the greater Portland region and Clark County, WA) with the 'Stream Definition' tool located within the Terrain Preprocessing menu of ArcHydro. The 'area' value determining density of the created stream network was adjusted until a value small enough to create stream channels representing all sampled stream segments was defined. The largest area value that created a stream network defining all channels 
that were sampled was $.05 \mathrm{~km}^{2}$. A raster stream-network (RSN) was created using these settings for utilization in sub-watershed definition.

To ensure that each defined sub-watershed was representative of the riparian habitat significant to amphibian populations at each stream site, the following steps were taken. Each watershed was defined using the 'Batch Sub-watershed Delineation' tool located within the Watershed Processing menu of ArcHydro. A shapefile was created to define batch points for each stream, which were simply points created to represent the outflow coordinates for each sub-watershed. Batch points were defined by overlaying the 'Site Location' stream segments with the original NHD stream network dataset utilized for site selection. The 'measure' tool was used to trace along the stream network to define a point 500 meters downstream from each sampled segment. The distance of 500 meters downstream was again used to represent the maximum dispersal distance of observed amphibian species. In instances where tracing 500 meters downstream of a stream segment resulted in batch points being located on confluences of third order or greater, batch points were designated upstream on the confluence such that these points were still 500 meters in stream-length from the end of the sampled transect. Separate sub-watersheds were delineated from these upstream-confluence points to later eliminate that area from inclusion within the delineated watershed.

Once batch points were created for all samples stream segments, watersheds were delineated individually by zooming in on the stream network raster surrounding the desired site. The yellow ' $x$ ' in the ArcHydro toolbar was selected to determine 
the control point for the batch sub-watershed delineation, which was defined on the created RSN. In many cases, the defined control point was identical to the batch point created from the NHD dataset. If batch point location differed significantly from the RSN, a control point was located on the RSN raster cell located closest to the pre-defined batch point. With the control points assigned, the 'Batch Subwatershed Delineation' tool was selected from the Watershed Processing menu of ArcHydro and the sub-watershed was delineated using the previously created FDR, FAC, and RSN layers as well as the appropriate RSN control point for each site. Where necessary, sub-watersheds defined from batch points located upstream along a larger confluence were deleted from the larger watershed defined from the '500 meters downstream' batch point. This step was necessary to avoid including large areas of adjacent watershed within the sub-watershed definition for each site. See Figure 3 for a visual example. 


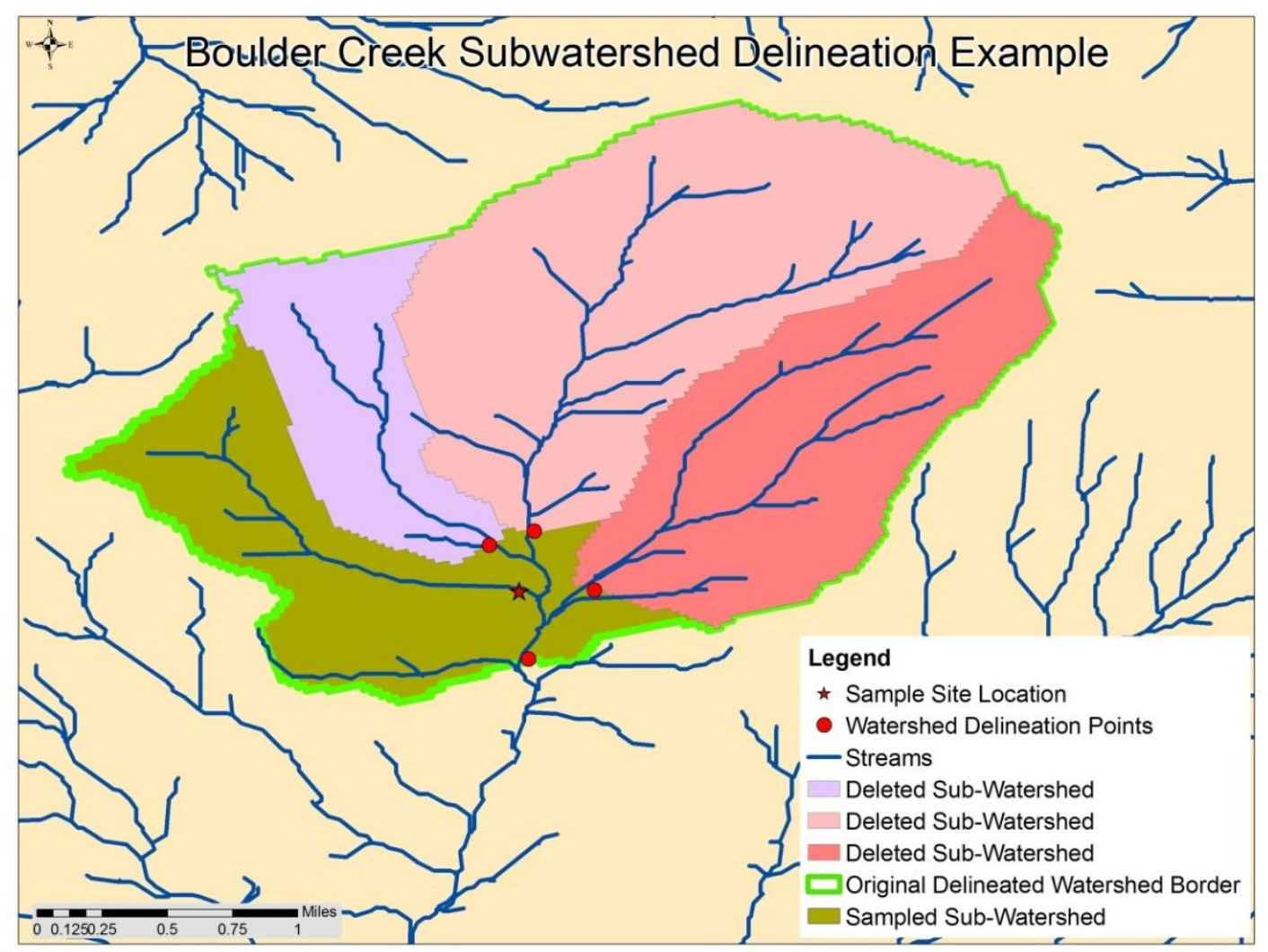

Figure 4 - Sub-watershed Delineation Complication Example. The display above illustrates the steps to delineate sub-watersheds when the delineation (or batch) point 500 meters downstream resulted in the inclusion of a large area not directly associated with the stream channel sampled. Separate delineation points were created upstream of the confluence reached by the original delineation point, always measuring 500 meters of stream channel away from the sampled transect. Watersheds delineated from these additional points were deleted from the larger delineated watershed to obtain a sub-watershed specific to the sampled channel.

\section{Surrounding Land-Use within the Sub-watershed}

Similarly to the land-use characterization of the 500 meter buffer, polygons representing the sub-watershed for each site were identified such that each was associated with a site in the polygon layer attribute table. The 'Identity' tool was then employed to create a layer of land-use polygons within the confines of each subwatershed polygon. This process was again repeated for both land-use datasets 
(the LIDAR-derived and NLCD layers) and associated attribute tables were exported for further analysis.

In addition to measuring land-use within the subwatershed boundaries, landuse within the vicinity of the stream-network was determined. Concentric buffers with distances of 50, 100, 200 and 300 meters were created using the 'Buffer' tool around a subset of NHD Flowlines within each subwatershed. Within the NHD Flowline dataset, only actual streams were selected and buffered for these analyses, omitting Flowlines representing pipes and artificial channels. These buffer layers were dissolved, identified by sampled site name, and edited/clipped to ensure that buffers from adjacent watersheds were not included in further analysis. Each buffer layer was then identified by both land-use datasets and desired attribute tables were exported for analysis.

\section{Impervious Surface Calculation}

To establish the area of impervious surface in each defined sub-watershed, the Impervious Surface raster layer derived from the 2006 NLCD dataset was used. Similarly to the land-use datasets, this raster was processed by converting it into a polygon shapefile for ease of processing in relation to the sub-watershed polygon shapefile. The sub-watersheds were then identified in relation to the Impervious Surface shapefile. Several attributes were added to the resultant attribute table to calculate impervious area. Total impervious area for each polygon was calculated via a field calculation multiplying the grid-code (representing the percentage of 
impervious surface in each polygon representing a raster cell) by the area of the associated polygons. A summary table was then created to sum all impervious areas per each sampled site name. This summary table was exported for further analysis.

\section{Statistical Analyses}

Statistical analysis was used to define correlations between amphibian species presence and collected environmental variables. Non-metric dimensional scaling, contingency tables and logistic regressions were used to identify individual variables with significant influence on amphibian presence, while occupancy modeling aided in identifying groups of variables that best predicted amphibian occupancy. Amphibian

abundances observed were not robust enough to perform correlation analyses between species abundances and the environmental variables measured. However, measures of presence/absence for obligate and facultative species were robust enough to further analyze relationships between amphibian occupancy and environmental variables. These groupings were utilized for the following statistical analyses.

\section{Non-Metric Dimensional Scaling}

Non-Metric Dimensional Scaling (NMDS) was utilized to group sites according to amphibian community composition and identify environmental variables that were useful in explaining the pattern of site groupings. Environmental variables determined to be significant in explaining the distribution of sites in the NMDS were further analyzed via logistic regressions. NMDS was performed with the R statistics 
program (version 2.15.0) with the 'vegan' and 'MASS' packages, which use the Bray-Curtis dissimilarity index for ordination construction.

\section{$\underline{\text { Logistic Regressions }}$}

Logistic Regressions (LRs) were used to determine the significance of individual environmental variables in predicting the occupancy (presence vs. absence) of amphibian functional groups (facultative and obligate species). Only land-use environmental variables identified by the Non-Metric Dimensional Scaling analysis as significant (to $\mathrm{p}<0.1$ ) were tested with logistic regression models to further distinguish variables that were useful in predicting the presence or absence of amphibians of separate functional groups (obligate and facultative). This method of analysis was preferred over linear regressions due to low numbers of detected amphibians at many sites. In addition, many of the collected environmental variables had non-normal distributions, widely ranging degrees of variance and varying levels of heteroscedactity. As logistic regressions are able to compensate for these problems, LRs were the preferred method of analysis, especially considering the large number of variables included in this study. LRs were conducted using the R statistics program, specifically utilizing the generalized linear modeling (glm) function with a binomial family and logit link function.

To test the predictive significance of each logistic regression model, null hypothesis testing methods were utilized to compare models containing environmental variables to null models including a constant. For each pair of 
variables, the difference between the log-likelihood of the null models (including amphibian occupancy and a constant) and a model containing the environmental variable was calculated with Formula \#1 and compared to a chi-square distribution. In addition, general measures of goodness-of-fit were calculated for each model found to be significant using Formula \#2:

Formula \#1: Distribution of Log Likelihoods $\left(\mathrm{G}^{2}\right)$

$$
G^{2}=-2(\log \text { likelihood of reduced model - log likelihood of full model })
$$

Formula \#2: Goodness-of-Fit of Log Likelihood Models $\left(\mathrm{r}_{\mathrm{L}}{ }^{2}\right)$

$$
r_{L}^{2}=1-\frac{\text { Log likelihood of full model }}{\text { Log likelihood of null model }}
$$

\section{Contingency Tables for Categorical Variables}

Contingency tables were used to evaluate the influence of three categorical variables (presence/absence of fish, presence/absence of crayfish, and private/public property ownership) in relation to amphibian functional group (obligate and facultative) presence/absence. P-values for each of these six relationships were calculated using the SigmaStat 3.5 and SigmaPlot 10.0 programs. All contingency tables were analyzed using a Fisher's Exact test due to the fact that expected values for some cells within four of the six evaluated tables were less than five. 


\section{Occupancy Modeling with the PRESENCE Program}

Because some documented absences might have reflected failure to detect amphibians rather than true absence, occupancy modeling was used to evaluate the relationships between the environmental variables and occupancy of the amphibian functional groups. This method is a preferable way to estimate predictive capabilities of site covariates due to its ability to account for 'false absences' (i.e. the inability to detect an amphibian species at a site where they are present) (MacKenzie et al., 2006). Because amphibians are considered cryptic and difficult to detect, false absences are common. Models were evaluated and ranked according to Akaike Information Criterion (AIC) values and related statistics. All models with AIC differences less than 2 from the top model were considered to have substantial empirical support, while those with AIC values 4 to 7 units less than the best fit model were judged to have moderate empirical support. Relative importance of environmental variables in occupancy modeling was also calculated by summing the AIC weights of models incorporating each variable (MacKenzie et al., 2006). A priori occupancy models were constructed to evaluate the hypotheses formulated for this study. Models were constructed to evaluate the predictive ability of groups of related variables in predicting the presence of obligate and facultative species. Variables included in each a priori model are listed below in Table 2. 
Table 2 - Variables Included in a priori Models for Occupancy Modeling. The table below lists the variables that were grouped into each of 9 a priori models used to estimate the predictive ability of these variables in relation to amphibian functional group occupancy. Models were grouped as such to test the defined hypotheses and satisfy objectives relating to determining the scale and nature of variables influencing stream amphibian populations.

\begin{tabular}{|c|c|}
\hline Model Theme & Variables Included \\
\hline Universal Model & All Significant Predictor Variables \\
\hline In-situ variables & $\begin{array}{l}\text { Canopy Density, Water Temperature \& Conductivity, } \\
\text { Substrate \& Total Cover, Mesohabitat, Pool Depth, Fish \& } \\
\text { Crayfish Presence }\end{array}$ \\
\hline $\begin{array}{l}\text { Mesohabitat } \\
\text { Variables }\end{array}$ & $\begin{array}{l}\text { Distances to Road Crossings, Patch Area \& Patchiness, } \\
\text { Impervious Surface (\% Cover \& Area), Land Ownership }\end{array}$ \\
\hline $\begin{array}{l}\text { Watershed } \\
\text { Variables }\end{array}$ & $\begin{array}{l}\text { All Land-use Variables within buffers of } 50 \text { meters width } \\
\text { and greater (excluding } 500 \text { meter concentric buffer) }\end{array}$ \\
\hline Forest Area & $\begin{array}{l}\text { Canopy Density, Patch Area \& Patchiness, Land-use } \\
\text { Variables Measuring Forested Land }\end{array}$ \\
\hline Urbanization & $\begin{array}{l}\text { Distance to Roads, Impervious Surface \% Cover \& Area, } \\
\text { Land-use Variable Measures of Paved Surfaces and } \\
\text { Developed Areas }\end{array}$ \\
\hline $\begin{array}{l}\text { Urbanization: } \\
\text { Secondary Effects }\end{array}$ & $\begin{array}{l}\text { Water Temperature \& Conductivity, \% Fine Substrate, Total } \\
\text { Cover, \% Run, Pool Depth }\end{array}$ \\
\hline $\begin{array}{l}\text { Moderate } \\
\text { Development }\end{array}$ & $\begin{array}{l}\text { Patchiness, Land-use Variables Measuring Herbaceous } \\
\text { Vegetation \& Agriculture }\end{array}$ \\
\hline $\begin{array}{l}\text { Most Predictive \& } \\
\text { Unique }\end{array}$ & $\begin{array}{l}\text { A subset of variables selected for having the highest } \\
\text { predictive value as determined from the LRs. Only one } \\
\text { variable per 'type group' (i.e. only one forest land-use } \\
\text { variable) }\end{array}$ \\
\hline
\end{tabular}

Of the variables listed for each a priori model above, only variables found to be significant via logistic regressions were actually included in occupancy models 
entered into the PRESENCE program. In addition, four variables not listed in Table 2 were tested for inclusion in models to account for environmental factors that may have influenced amphibian detection probabilities during sampling periods. These variables include air temperature $\left({ }^{\circ} \mathrm{C}\right)$, date of sampling, and weather at the beginning and end of each sample session. Subsets of these detection variables were evaluated using the occupancy modeling program to determine if they contributed to increased goodness-of-fit values for occupancy models of each amphibian functional group. Detection variables that did improve goodness-of-fit were included in all models run for each respective amphibian group. 


\section{RESULTS}

\section{Sites Sampled}

Stream-associated amphibian communities were assessed in 37 forested stream segments within the Portland, Oregon region between June $21^{\text {st }}$ and September $21^{\text {st }}$ of 2011. Twenty-two streams were located within the Urban Growth Boundary (UGB) of Portland and the cities immediately adjacent to Portland. Sixteen streams were located in Clark County, Washington (See Figure 4 for a map of the sites).

\section{Amphibian Detections}

In total, 242 amphibians were captured and identified representing seven different species from six different genera (Table 3). Two obligate stream amphibians were observed (Dicamptadon tenebrosus and Rhyacotriton cascadae), while five different facultative species were detected (Plethadon vehiculum, Plethadon dunni, Taricha granulosa granulosa, Rana aurora and Pseudacris regilla). Amphibians were observed at 17 of the 37 sampled stream segments. Stream obligate species occurred at 11 sites while stream facultative species occurred at 15 of the stream sites. Both facultative and obligate stream amphibians were observed and recorded at 9 sites, 6 of which were located within Forest Park (Figure 5). Dicamptadon tenebrosus was the most abundant species, with 143 individuals observed during the sampling period, while Plethadon vehiculum was the most commonly detected species, observed at 11 different sites. Refer to Table 4 for a 
complete list of overall species abundances and distribution. Refer to Figure 5 for a map of species richness by sample site.

Table 3 - List of Observed Amphibian Species. The table below represents a comprehensive list of the species observed during the sampling period within the sampled stream transects as well as the number of sites at which each species occurred and the total number of individuals observed. See Appendix D for a complete list of species present at each site.

\begin{tabular}{|l|l|l|c|c|}
\hline Amphibian Species & Common Name & $\begin{array}{l}\text { Obligate } \\
\text { /Facultative }\end{array}$ & $\begin{array}{l}\text { \# of Sites } \\
\text { Observed at }\end{array}$ & $\begin{array}{l}\text { \# of Individuals } \\
\text { Observed }\end{array}$ \\
\hline Dicamptadon tenebrosus & $\begin{array}{l}\text { Pacific/Coastal Giant } \\
\text { Salamander }\end{array}$ & Obligate & 10 & 143 \\
\hline Rhyacotriton cascadae & $\begin{array}{l}\text { Cascade Torrent } \\
\text { Salamander }\end{array}$ & Obligate & 1 & 7 \\
\hline Plethadon vehiculum & $\begin{array}{l}\text { Western Red-backed } \\
\text { Salamander }\end{array}$ & Facultative & 11 & 70 \\
\hline Plethadon dunni & Dunn's Salamander & Facultative & 4 & 13 \\
\hline granulosa & Rough-Skinned Newt & Facultative & 2 & $\mathbf{3}$ \\
\hline $\begin{array}{l}\text { Rana aurora } \\
\text { Pseudacris regilla }\end{array}$ & $\begin{array}{l}\text { Northern Red-Legged } \\
\text { Frog }\end{array}$ & Facultative & 2 & $\mathbf{5}$ \\
\hline
\end{tabular}




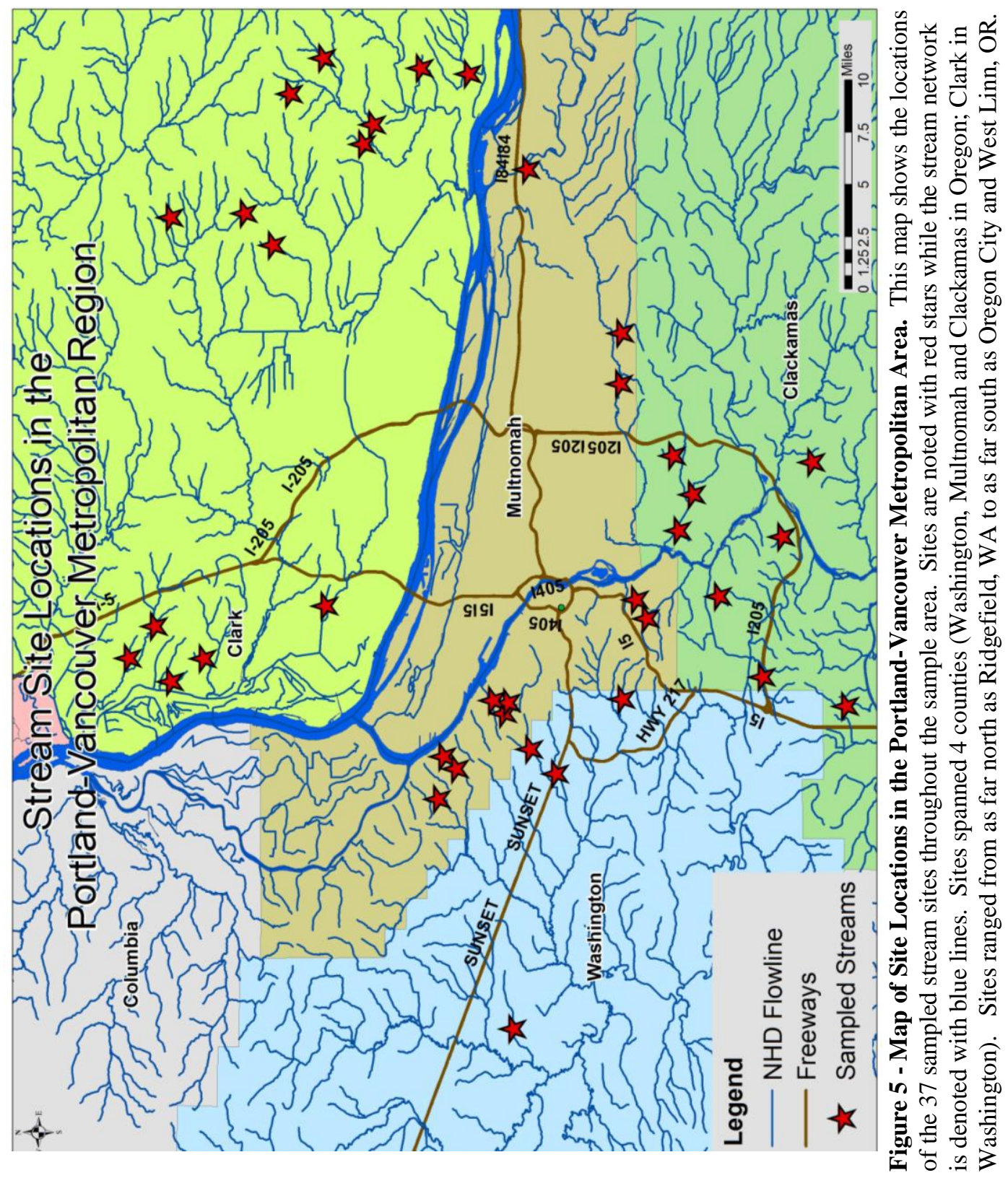




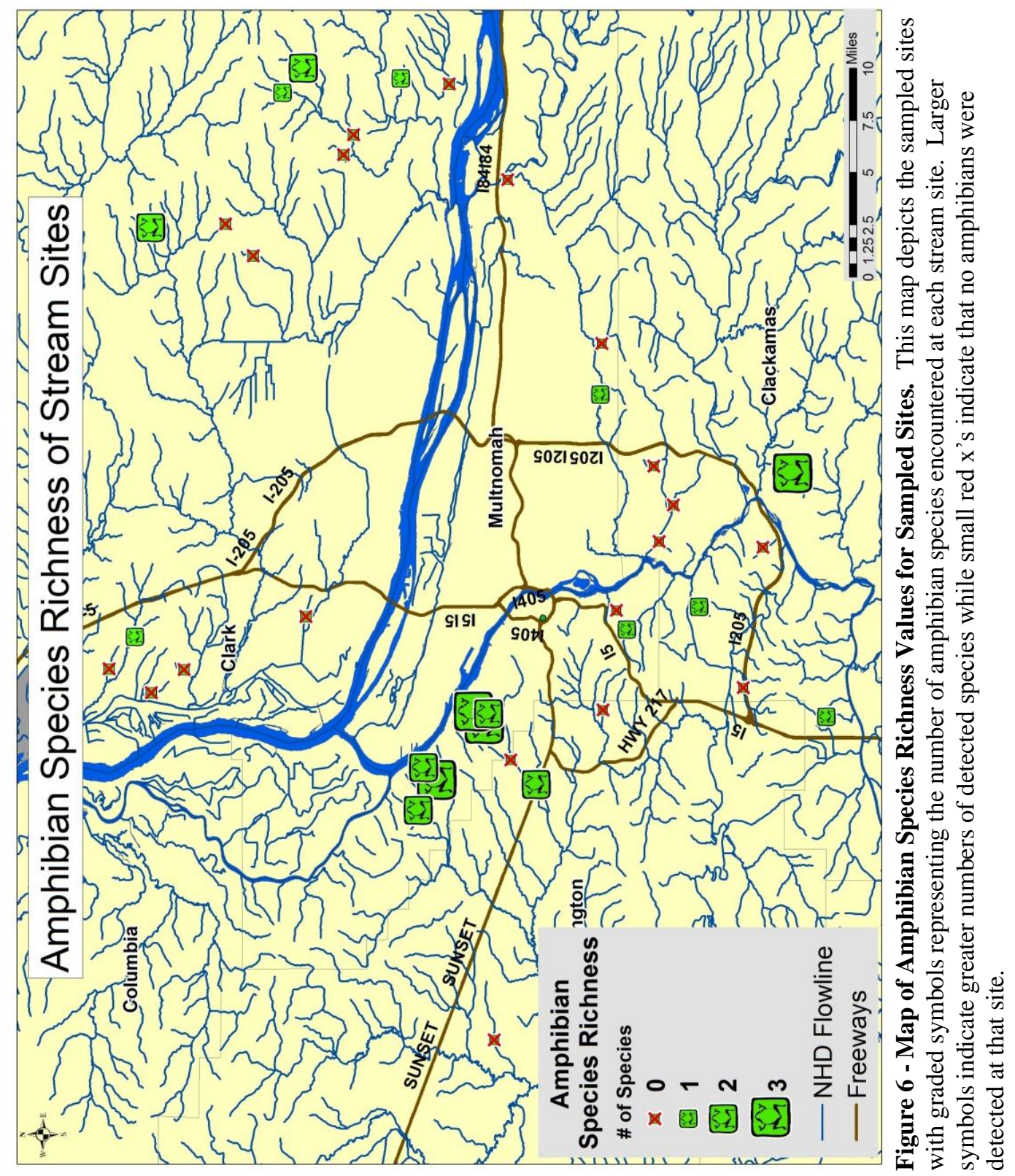




\section{In-Situ Environmental Measurements}

ANOVA tests were performed to compare several environmental variables among sites grouped by amphibian functional groups. These groupings resulted in overlapping datasets between sites with facultative species and sites with obligate species. Due to this lack of independence between site groupings, the ANOVA analyses provided here and elsewhere violate assumptions of independence and should be seen as descriptive and not statistical conclusions.

\section{Water Quality}

Stream temperature measurements were variable, ranging from $11.3^{\circ} \mathrm{C}$ to $17.5^{\circ} \mathrm{C}$. Streams with obligate amphibians averaged lower water temperatures $\left(13.1^{\circ} \mathrm{C} \pm 0.3\right)$ than those with facultative species $\left(14.0^{\circ} \mathrm{C} \pm 0.4\right)$, and these two groups of streams were significantly cooler than streams in which no amphibians were detected $\left(14.8^{\circ} \mathrm{C} \pm 0.3\right)(\mathrm{p}<0.05$; Figure 7$)$. Specific conductivity of streams varied from $17.5 \mu \mathrm{S}$ to $273.1 \mu \mathrm{S}$. Sites where no amphibians were detected had higher average conductivity $(146.5 \mu \mathrm{S} \pm 13.3)$ than sites with facultative species $(126.0 \mu \mathrm{S} \pm$ 16.4). Mean specific conductivity at sites with obligate species was significantly below that of streams where no amphibians or facultative species were detected $(81.0 \mu \mathrm{S} \pm 14.7)(\mathrm{p}<0.05 ;$ Figure 8$)$. 


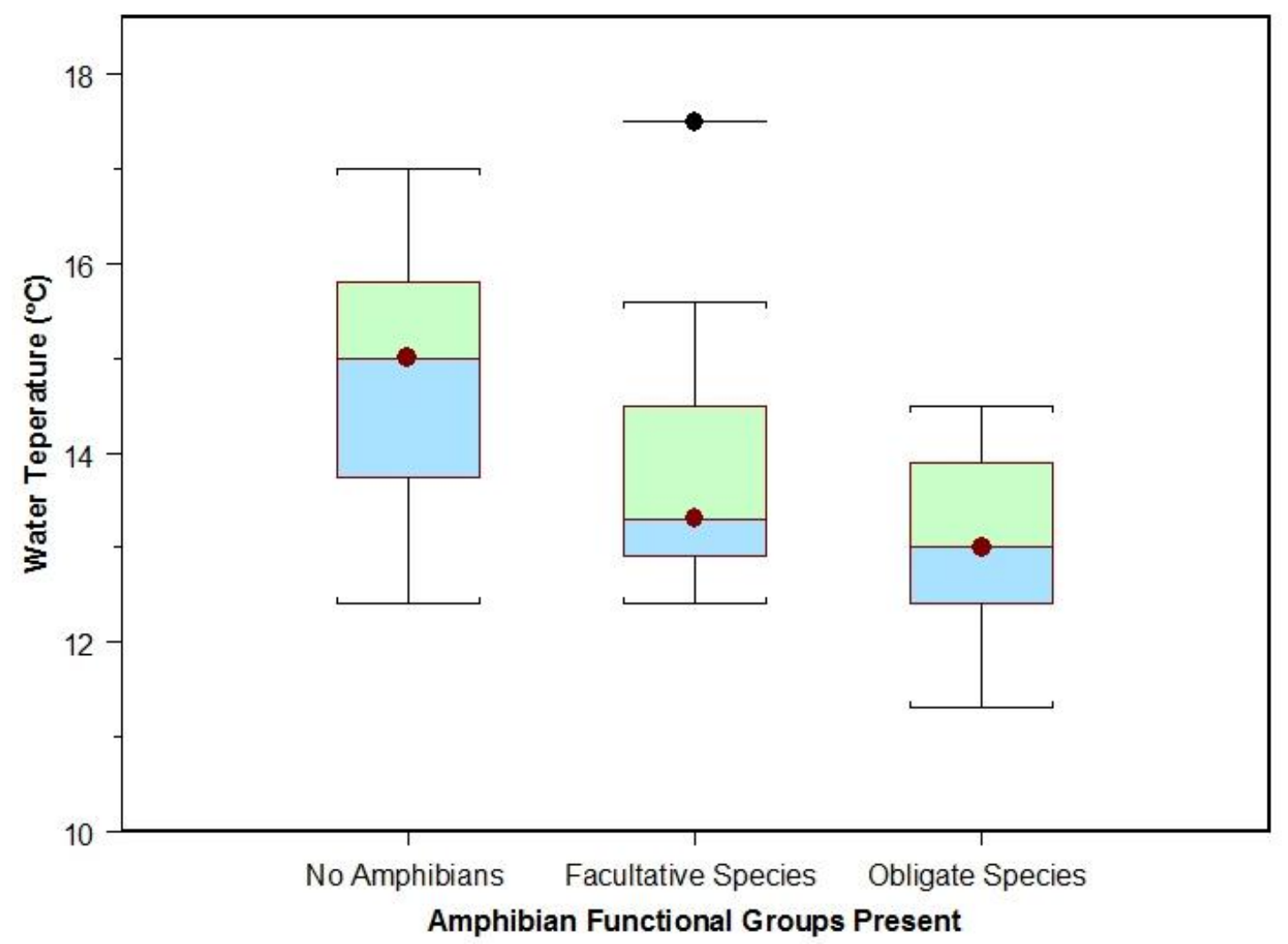

Figure 7 -Water Temperature by Amphibian Functional Group. This graph displays the median water temperature for sites where each amphibian functional group was detected. Boxplots display the median, interquartile range $\left(25^{\text {th }}\right.$ and $75^{\text {th }}$ percentiles $), 10^{\text {th }}$ and $90^{\text {th }}$ percentiles and outliers (represented by the floating line with a point). Sites without amphibians present had the highest median water temperatures, while sites with obligate species present had the lowest median water temperatures $(\mathrm{p}<0.05)$. 


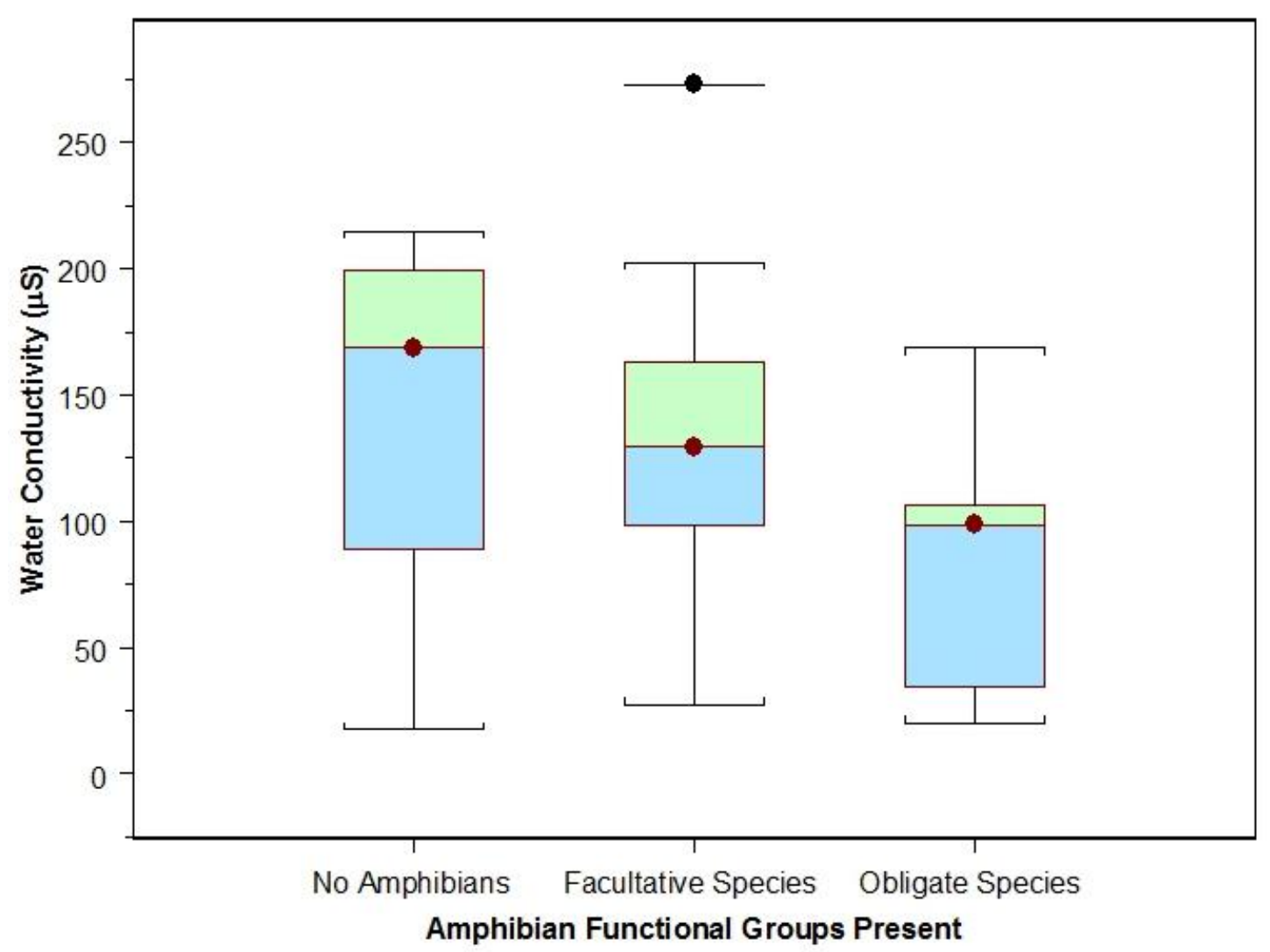

Figure 8 - Specific Conductivity by Amphibian Functional Group. This graph represents the range of conductivity values measured at sites where each amphibian functional group was encountered. Boxplots display the median, interquartile range $\left(25^{\text {th }}\right.$ and $75^{\text {th }}$ percentiles $), 10^{\text {th }}$ and $90^{\text {th }}$ percentiles and outliers (represented by the floating line with a point). Sites with obligate stream amphibians present had the lowest median conductivity $(\mathrm{p}<0.05)$.

\section{$\underline{\text { Stream Substrate }}$}

Percentage of fine substrate (particles of size 0-4.0 mm) ranged from $11.3 \%$ to $74.4 \%$, while coarse substrate (particles $>4.0 \mathrm{~mm}$ ) ranged from $25.6 \%$ to $87 \%$ of each stream. Bedrock was not visible at many sites but represented $39.4 \%$ of the substrate at one site. Sites where no amphibians were detected averaged higher percentages of fine substrate $(46.2 \% \pm 4.6)$ and lower percentages of coarse substrates $(49.1 \% \pm 4.2)$ than sites with facultative species $(29.0 \% \pm 3.7$ fine substrate; $64.0 \% \pm 4.4$ coarse sediment $)$ and sites with obligate species $(28.5 \% \pm 4.6$ fine substrate; $69.2 \% \pm 4.9$ 
coarse substrate). Obligate amphibians were only detected at sites with less than $12 \%$ bedrock and over 50\% coarse substrate (Figure 9).

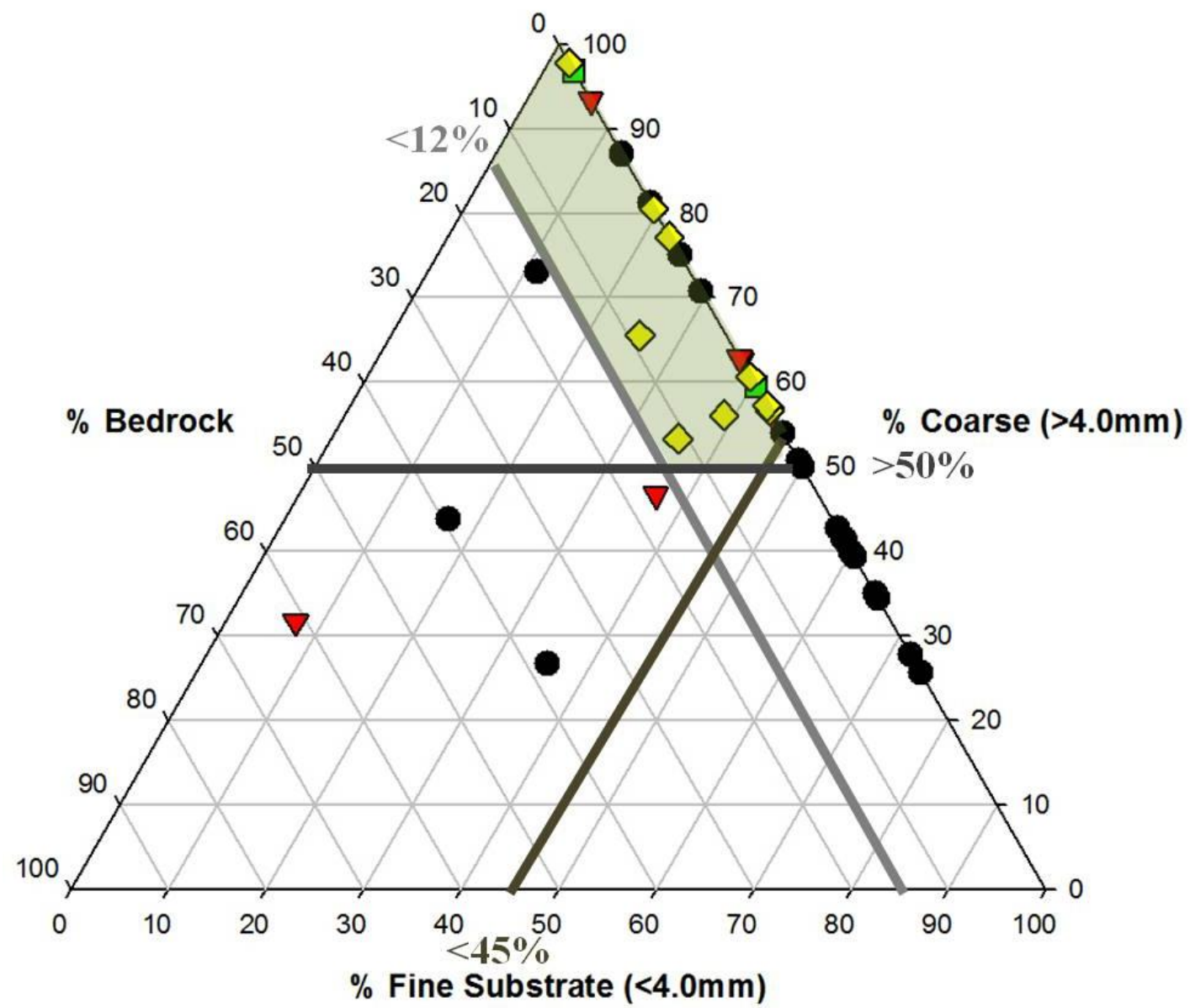

$\begin{array}{ll}\nabla & \text { No Amphibians } \\ \nabla & \text { Faculative } \\ \square & \text { Obligate } \\ \diamond & \text { Facultative \& Obligate }\end{array}$

Figure 9 - Substrate Composition Graphed by Amphibian Groups Observed. This graph depicts the substrate composition at each site. Sites are represented by symbols indicating what amphibian groups were detected at each. The shaded area contains all sites where obligate species were detected. Bolded lines indicate thresholds of each substrate class for these sites. No site with obligate species had substrate composed of less than $50 \%$ coarse material. In addition, only one site with obligate amphibians had over $10 \%$ exposed bedrock substrate.

The average number of cover objects varied significantly between sites, ranging from 69 cover objects within the 30 meter sampled transect to 780 objects. 
Streams with no amphibians detected averaged 322 cover objects $( \pm 46.4)$. Sites with facultative species averaged a greater amount of cover (438 objects \pm 58.8 ) and sites with obligate species present averaged the greatest amount of cover ( 620 objects $\pm 62.8)(\mathrm{p}<0.05$; Figure 10). Overall, 14,718 cover objects were lifted and searched over the 2011 sampling season.

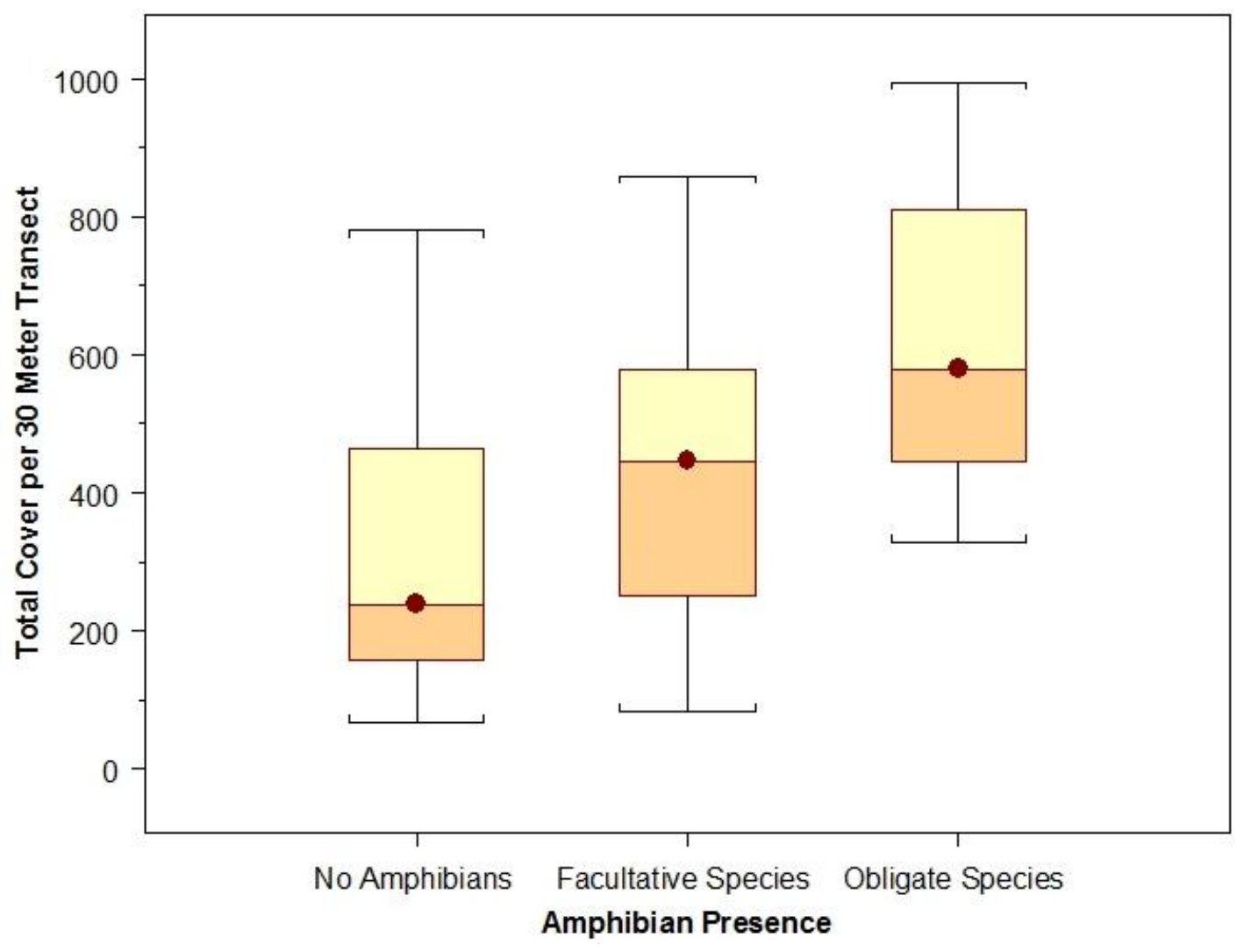

Figure 10 -Number of Cover Objects Searched per Transect by Amphibian Functional Group. This graph depicts the average number of cover objects searched within the established 30-meter stream transect. Boxplots display the median, interquartile range $\left(25^{\text {th }}\right.$ and $75^{\text {th }}$ percentiles $), 10^{\text {th }}$ and $90^{\text {th }}$ percentiles. For each site, the number of cover objects searched was averaged between the three observers to account for varying degrees of thoroughness in search efforts. Sites with obligate stream amphibians present had the highest average number of cover objects $(\mathrm{p}<0.05)$. 


\section{Meso-habitat}

The ratio of three stream meso-habitat types (riffle, pool and run) was calculated for comparison. Percentage of riffle meso-habitat ranged from $6.7 \%$ to $73.3 \%$ per stream transect, pool habitat percentages varied between 0 and $90 \%$ and stream habitat classified as a run ranged from $11.7 \%$ to $93.3 \%$. Sites where obligate species were detected had a higher average percentage of riffle meso-habitat $(56.4 \% \pm$ $0.1)$ than sites with facultative species $(44.8 \% \pm 0.1)$ and sites where no amphibians were detected $(35.7 \% \pm 0.1)$. Though amounts of riffle and run habitat varied significantly between streams with obligate species, no site where obligate species were detected had greater than $30 \%$ pool meso-habitat (Figure 11). 


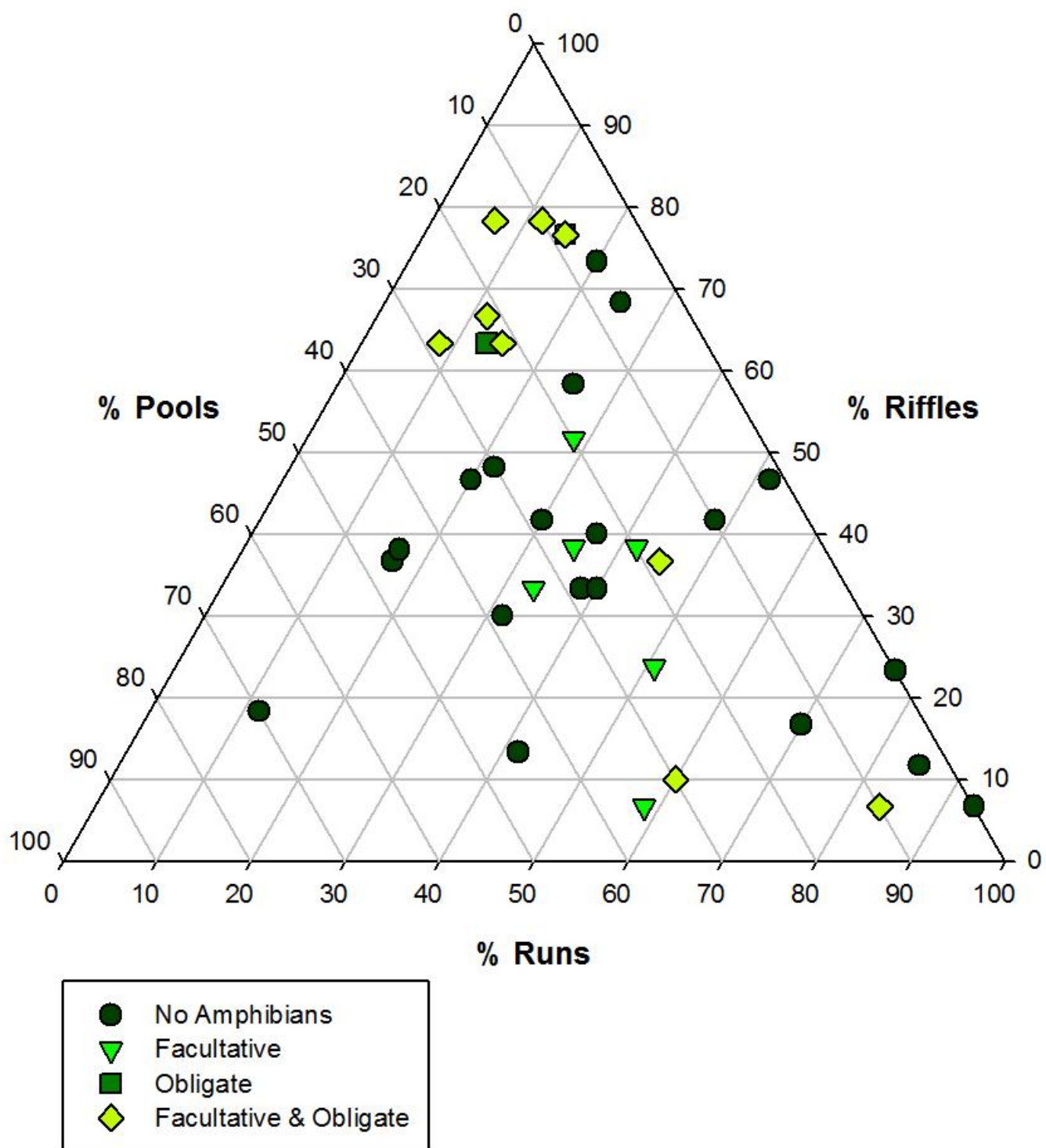

Figure 11 -Meso-habitat Ratio Among Sampled Sites Graphed by Amphibian Groups Observed. Sites are represented here depicting the general characteristics of stream meso-habitat in relation to what amphibian groups were detected. Sites with obligate species were not detected in sites with less than $50 \%$ riffle habitat or greater than $15 \%$ pool habitat.

\section{Vegetation/Canopy Cover}

The amount of canopy cover varied little between streams, though the minimum observed canopy cover was $47.3 \%$, compared with the maximum of $95.3 \%$. Sites where obligate species were detected had only slightly higher average canopy 
coverage $(91.2 \% \pm 0.8)$ when compared to sites with facultative species $(91.0 \% \pm 1.1)$ or no amphibians present $(89.0 \% \pm 2.3)$.

\section{Presence/Absence of Predators}

Crayfish were detected at 27 of the 37 sampled sites. Fish were detected at 23 of the 37 sampled streams. While the detection of crayfish differed little between sites categorized by amphibian functional group presence, fish were detected much more often at sites with no amphibians present (70\% of sites) than they were at sites where obligate species were detected (27\% of sites) (Table 4$)$.

Table 4 - Presence of Predators/Competitors at Sampled Sites. This table represents the percentage of sites occupied by fish and crayfish for each site grouping (as defined by amphibian functional group occupancy).

\begin{tabular}{|l|c|c|}
\hline $\begin{array}{l}\text { Site Amphibian } \\
\text { Detections }\end{array}$ & $\begin{array}{c}\text { Crayfish Detection (\% } \\
\text { of Sites Occupied) }\end{array}$ & $\frac{\text { Fish Detection (\% of }}{\text { Sites Occupied) }}$ \\
\hline No Amphibians (20 sites) & $15(75 \%)$ & $14(70 \%)$ \\
\hline $\begin{array}{l}\text { Facultative Species (15 } \\
\text { sites) }\end{array}$ & $11(73 \%)$ & $6(40 \%)$ \\
\hline Obligate Species (11 sites) & $7(64 \%)$ & $3(27 \%)$ \\
\hline
\end{tabular}

\section{Biogeographic Environmental Measurements}

\section{Distance to Nearest Road}

The distance to the closest road from each sampled transect varied between 25 meters and 711 meters, averaging 178 meters for all sites. Distances from sites to upstream road crossings were greatest on average for sites without amphibians (395 meters \pm 61$)$ when compared to that for sites with facultative species $(282 \mathrm{~m} \pm 73$ ) 
and those with obligate species $(310 \mathrm{~m} \pm 88)$. However, sites with obligate species had the greatest average distances to road crossings downstream $(956 \mathrm{~m} \pm 244)$ and to the nearest road crossing $(418 \mathrm{~m} \pm 170)$. Sites without amphibians averaged the least distance to road crossings downstream (444 $\mathrm{m} \pm 138$ ) and to the nearest road crossing $(178 \mathrm{~m} \pm 41)$ while sites with facultative species averaged distances in between those of sites with obligate species and those with no amphibians (710 $\mathrm{m} \pm 190$ to downstream road crossings; $198 \mathrm{~m} \pm 56$ to the nearest road crossing). Though obligate species were in streams further from roads, distance to road crossings did not appear to have a strong effect on amphibian presence in this study (Figures 12 and 13). 


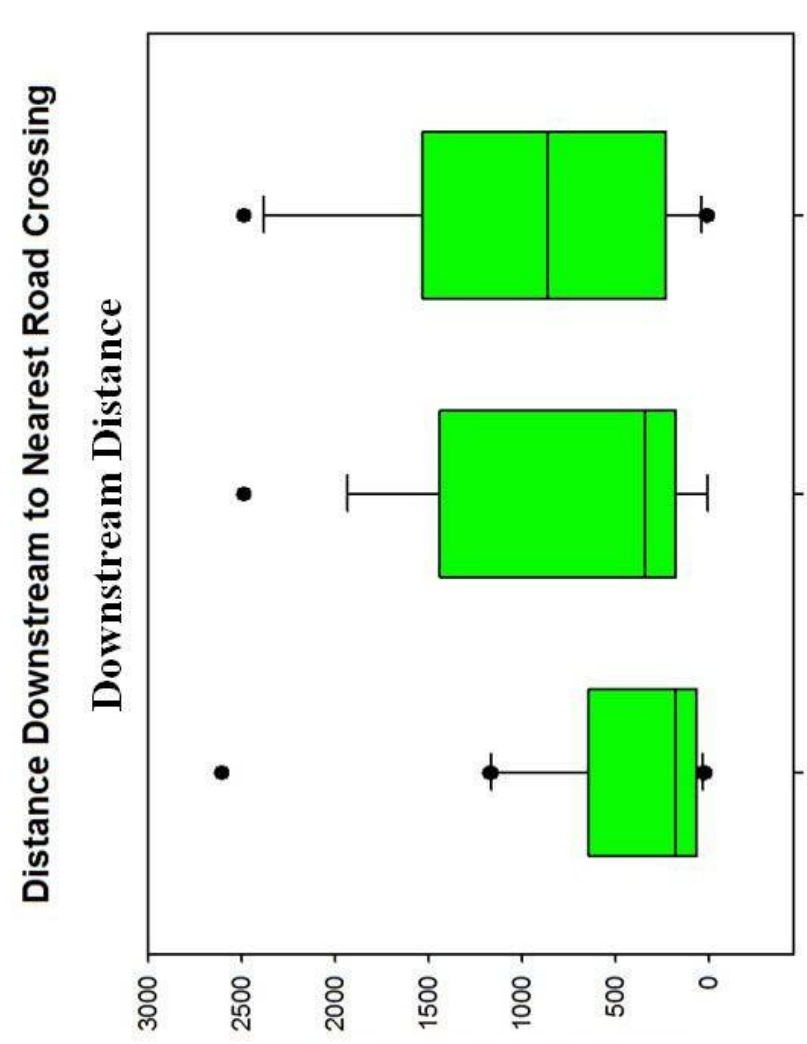

(u) bu!ssodo peoy of әэuełs!a

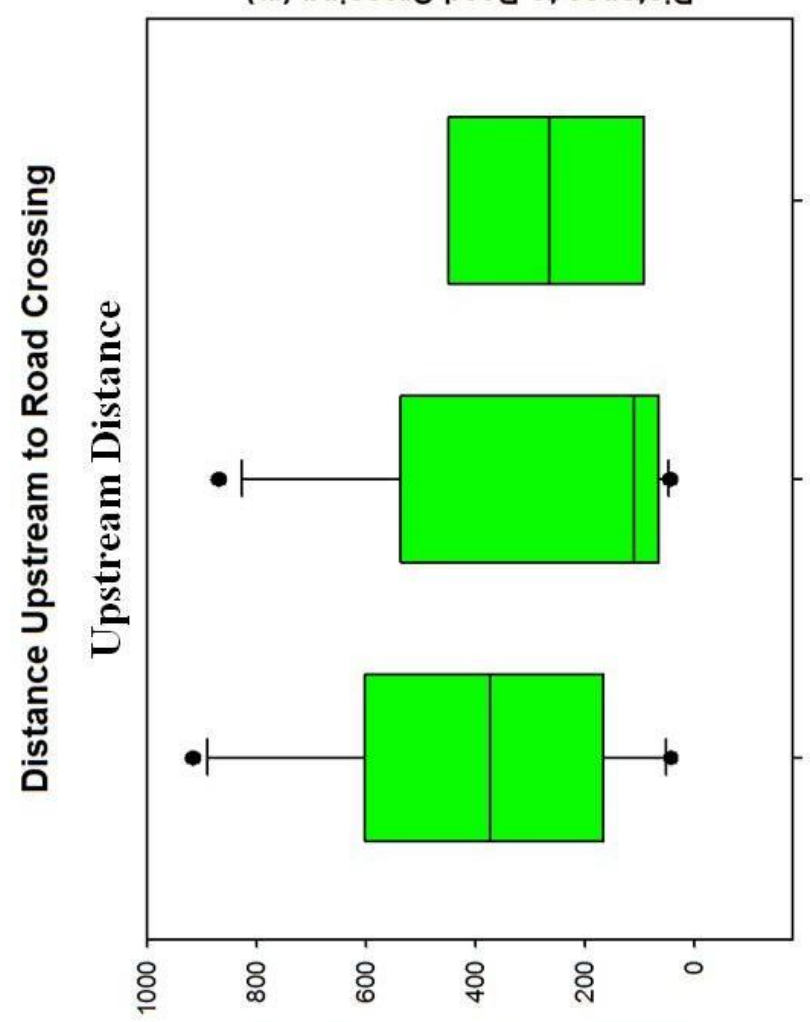

(u) Gu!ssodכ peoy of әэuełs!a

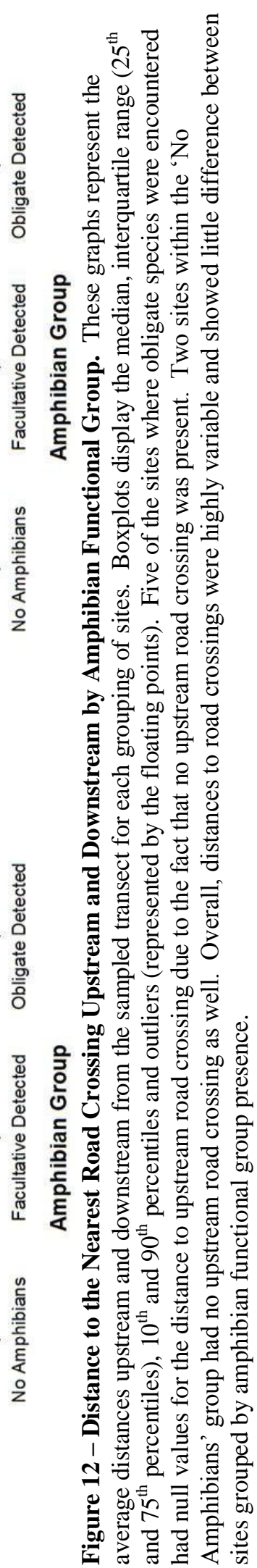




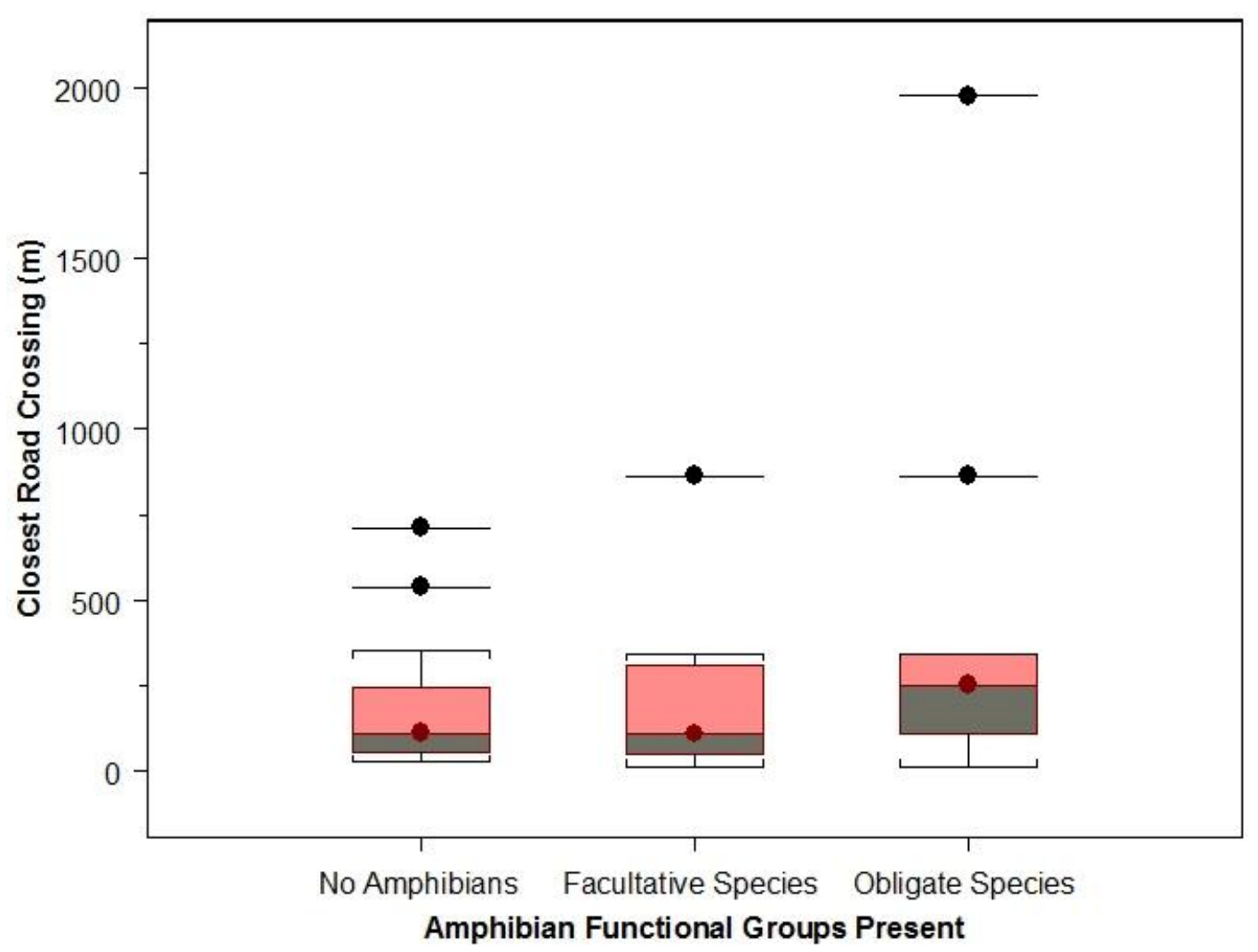

Figure 13 - Distance to Nearest Road Crossing by Amphibian Functional Group. This graph represents the median distance to the nearest road crossing for each grouping of sites. Boxplots display the median, interquartile range $\left(25^{\text {th }}\right.$ and $75^{\text {th }}$ percentiles), $10^{\text {th }}$ and $90^{\text {th }}$ percentiles and outliers (represented by the floating line with a point). The minimum distance between the upstream and downstream distances was selected for each site. Sites without amphibians were an average of 178 meters from a road crossing, while transects with facultative and obligate species were an average of 198 meters and 418 meters, respectively, from the nearest road crossing. Though distances were greatest on average for sites with obligate species, distances to nearest road crossings were highly variable and showed little difference between sites grouped by amphibian functional group presence.

\section{Patch-size Delineation}

ANOVA analyses were also used to compare forest patch area statistics between sites divided by amphibian functional groups. The area of contiguous forested habitat adjacent to each stream site varied widely between individual sites, ranging from as small as $.006 \mathrm{~km}^{2}$ to as large as $30.3 \mathrm{~km}^{2}$. Overall, sites averaged $2.38 \mathrm{~km}^{2}$ of adjacent, uninterrupted forested land. Sites with facultative species present averaged significantly higher patch size $\left(7.25 \mathrm{~km}^{2} \pm 1.98\right)$ than sites without 
amphibians $\left(2.38 \mathrm{~km}^{2} \pm 1.51\right)$, while sites with obligate species averaged significantly higher forested patch size $\left(12.04 \mathrm{~km}^{2} \pm 2.28\right)$ than sites with facultative species.

Patchiness, or a general measure of the proportion of edge habitat within each

forested area (measured as perimeter/area), was lowest in sites where obligate stream amphibian species were detected $\left(0.012 \mathrm{~km} / \mathrm{km}^{2} \pm 0.002\right)$ and highest for sites where no amphibians were detected $\left(0.049 \mathrm{~km} / \mathrm{km}^{2} \pm 0.006\right)(\mathrm{p}<0.05$; Figure 14$)$. 


\section{Area of Surrounding Forest Patch}
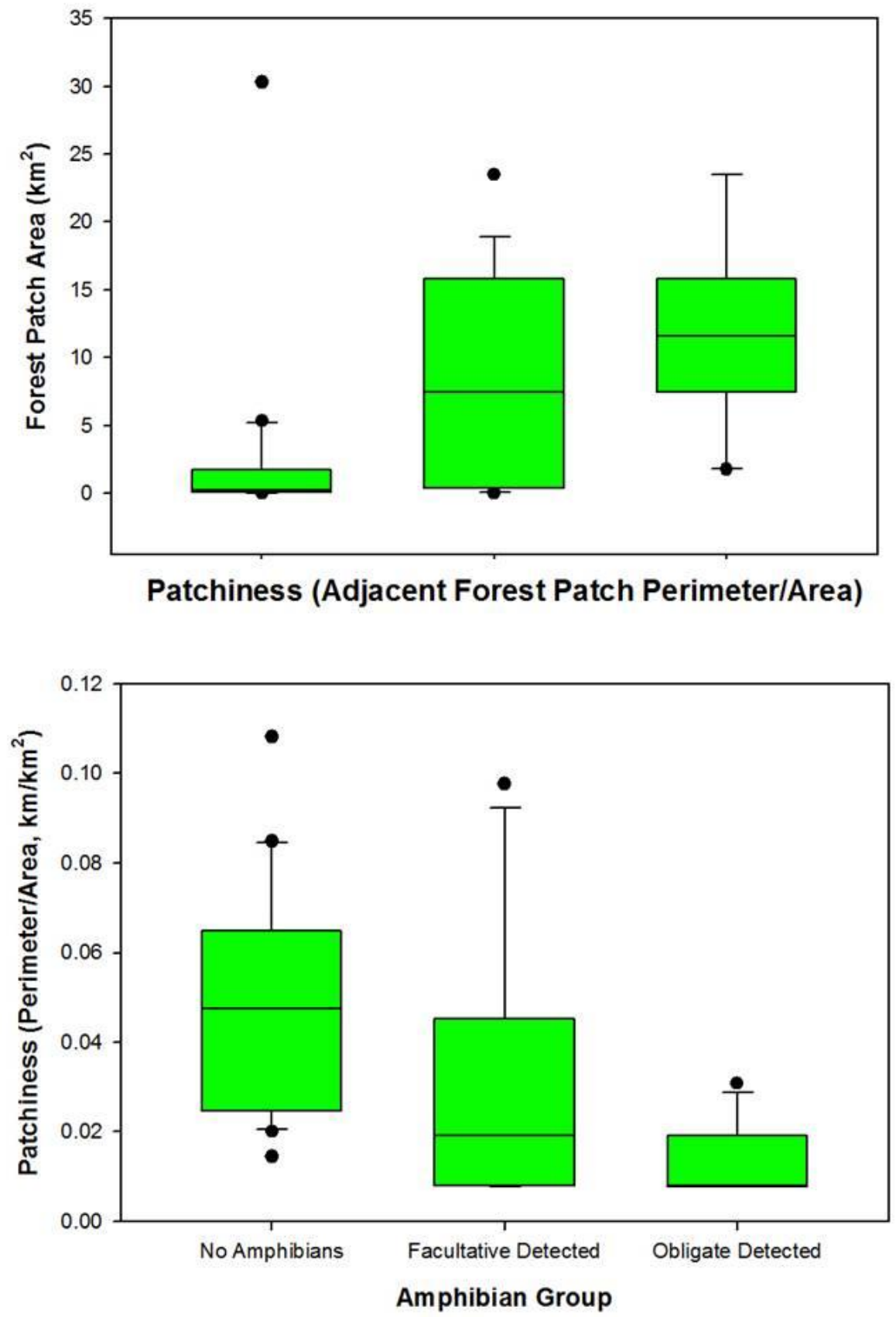

Figure 14 - Forest Patch Area and Edge Habitat by Amphibian Functional Group. These figures depict the area of contiguous forest habitat adjacent to each sampled transect as well as the patchiness, or overall ratio of edge habitat (measured as perimeter/area), for each forested patch. Boxplots display the median, interquartile range $\left(25^{\text {th }}\right.$ and $75^{\text {th }}$ percentiles), $10^{\text {th }}$ and $90^{\text {th }}$ percentiles and outliers (represented by the floating points). Values for area and patchiness were averaged over each site grouping. Sites with obligate amphibian species present had the highest average area of surrounding forest and the lowest average measurement of Patchiness for the surrounding forested area. 


\section{Sub-Watershed Delineation}

Sub-watershed delineation resulted in sub-watersheds ranging from $0.33 \mathrm{~km}^{2}$ to $62.9 \mathrm{~km}^{2}$ in area. On average, sub-watersheds were $5.04 \mathrm{~km}^{2}$. Sub-watersheds were located within four counties throughout the Portland-Vancouver metropolitan region, including Washington, Multnomah and Clackamas County in Oregon as well as Clark County in Washington (Figure 15).

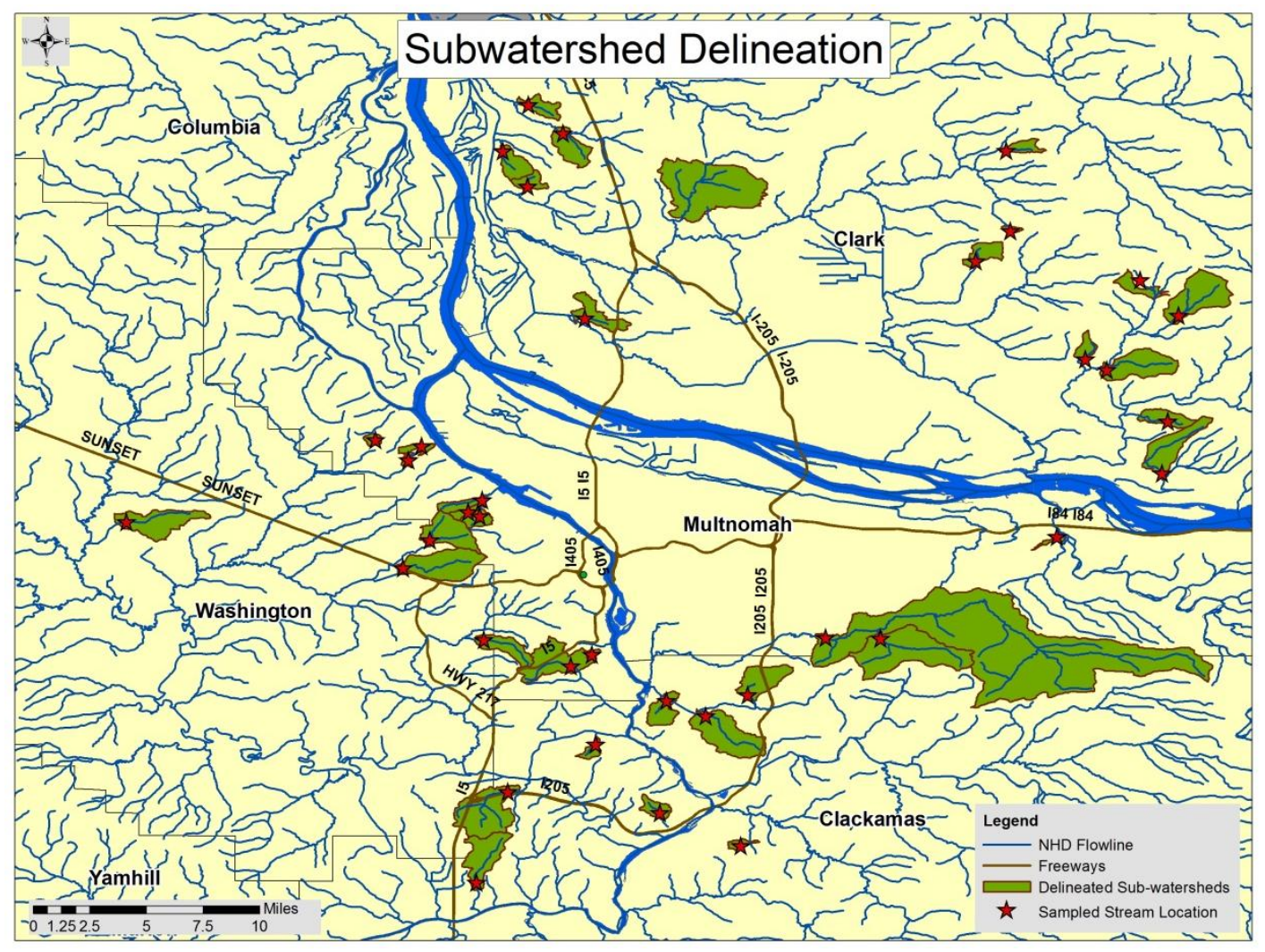

Figure 15 - Map of Sub-watersheds Delineated for Each Sampled Site. The above map depicts the size and shapes of the various sub-watersheds delineated from points established 500 meters downstream of each stream transect. The smallest watershed was $0.33 \mathrm{~km}^{2}$ while the largest watershed, delineated around Davis Creek, was $62.9 \mathrm{~km}^{2}$.

\section{Land-use Measurements}

Land-use measurements taken for varying buffer widths are displayed in tertiary graphs below with sites coded by the presence or absence of facultative 
species, obligate species or both. Sites with both groups of species as well as those with only obligate species were located in stream networks where most of the surrounding landscape was forested. As buffer width was increased, a few sites with obligate species present began migrating downward on the plot, indicating a more varied composition of land-uses within the surrounding landscape. No site with obligates had more than $20 \%$ Impervious Surface in the surrounding landscape, regardless of buffer width. Eight out of eleven sites with obligate species were located in watersheds where riparian areas had greater than $80 \%$ forested area and less than $8 \%$ impervious surfaces regardless of buffer width. Sites with no amphibians or only facultative species were spread throughout the plots in no discernible pattern (Figures 16, 17 and 18). 

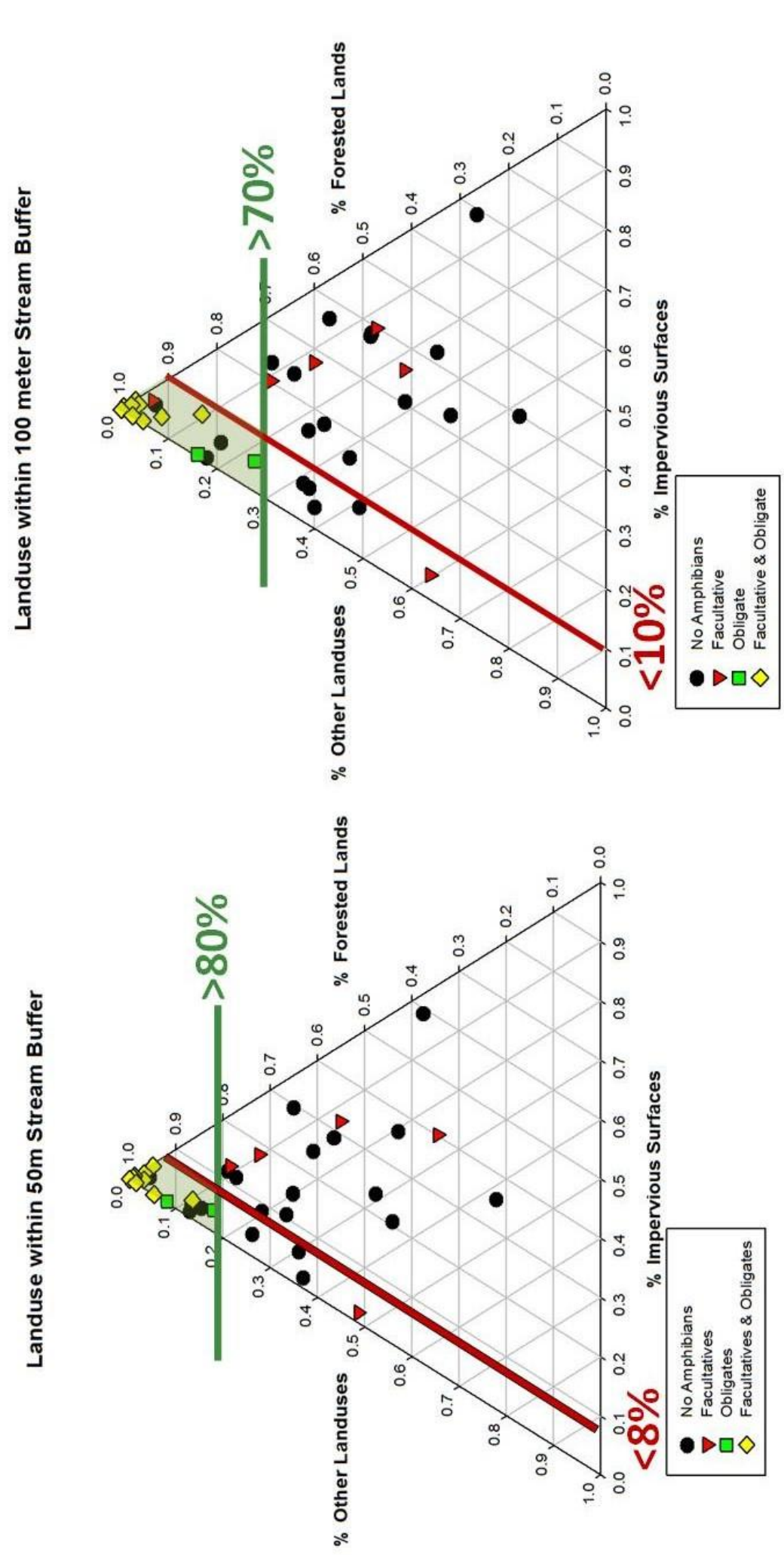

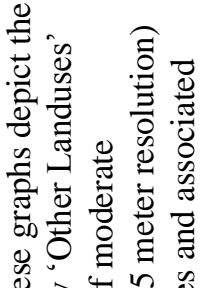

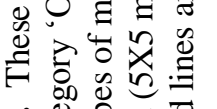

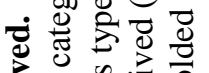

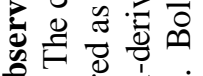

О.

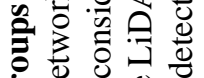

ป

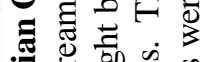

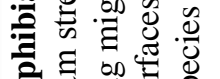

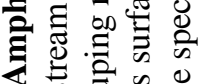

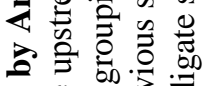

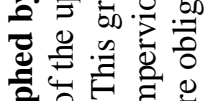

त्री०

可它

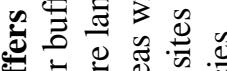

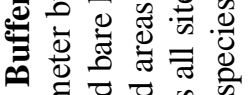

छี छ

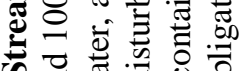

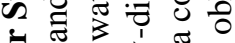

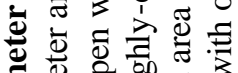

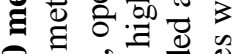

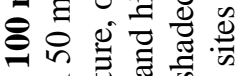

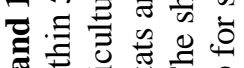

ส.

包 焉它

的论

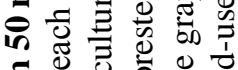

\#

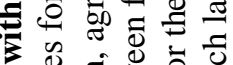

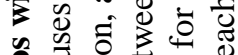

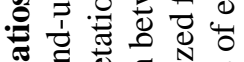

ฯ 흐

$\forall$ 늉

足

일

जิ

1́

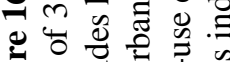

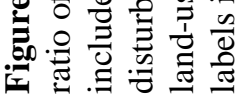




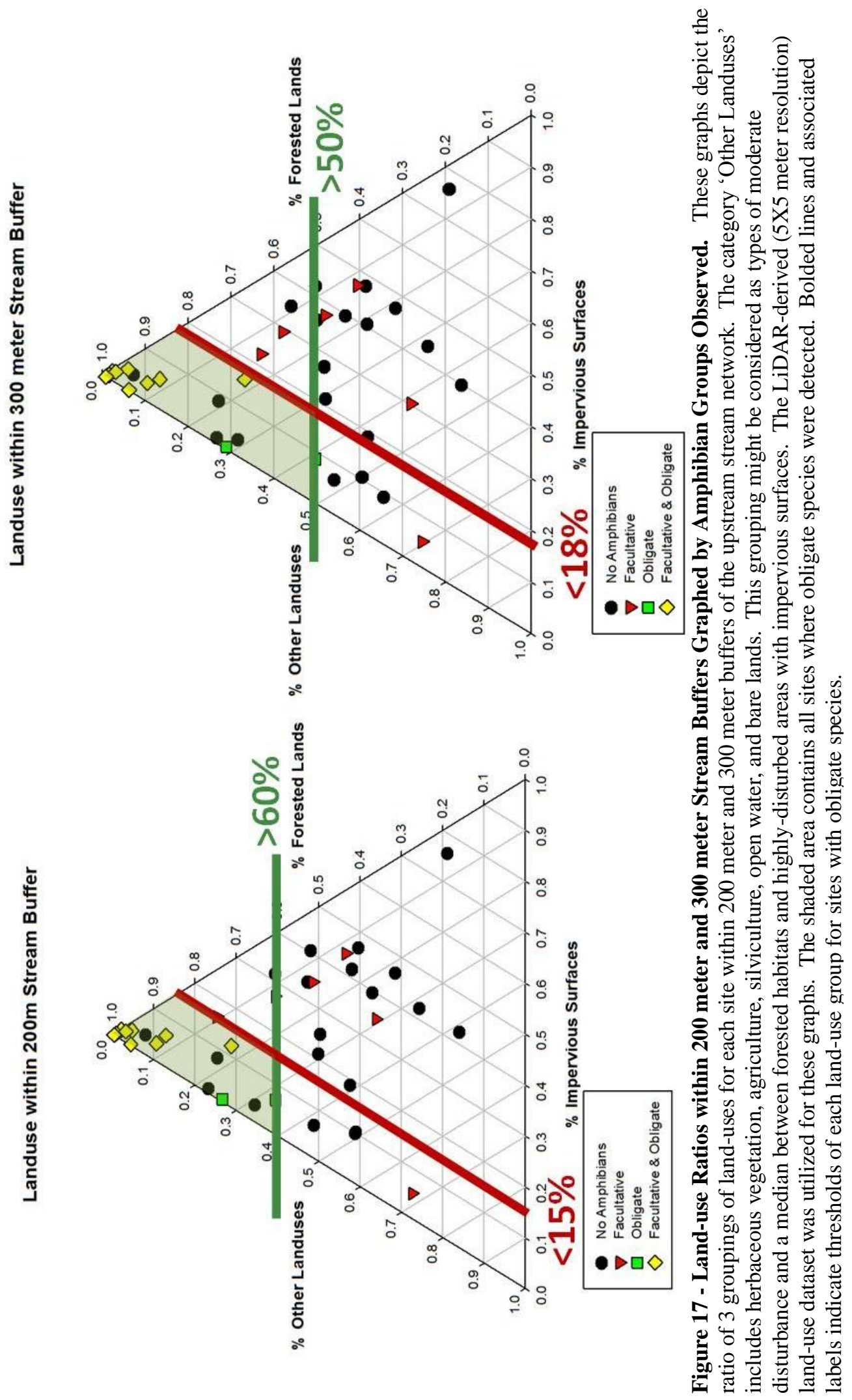




\section{Landuse within the Surrounding Subwatershed}

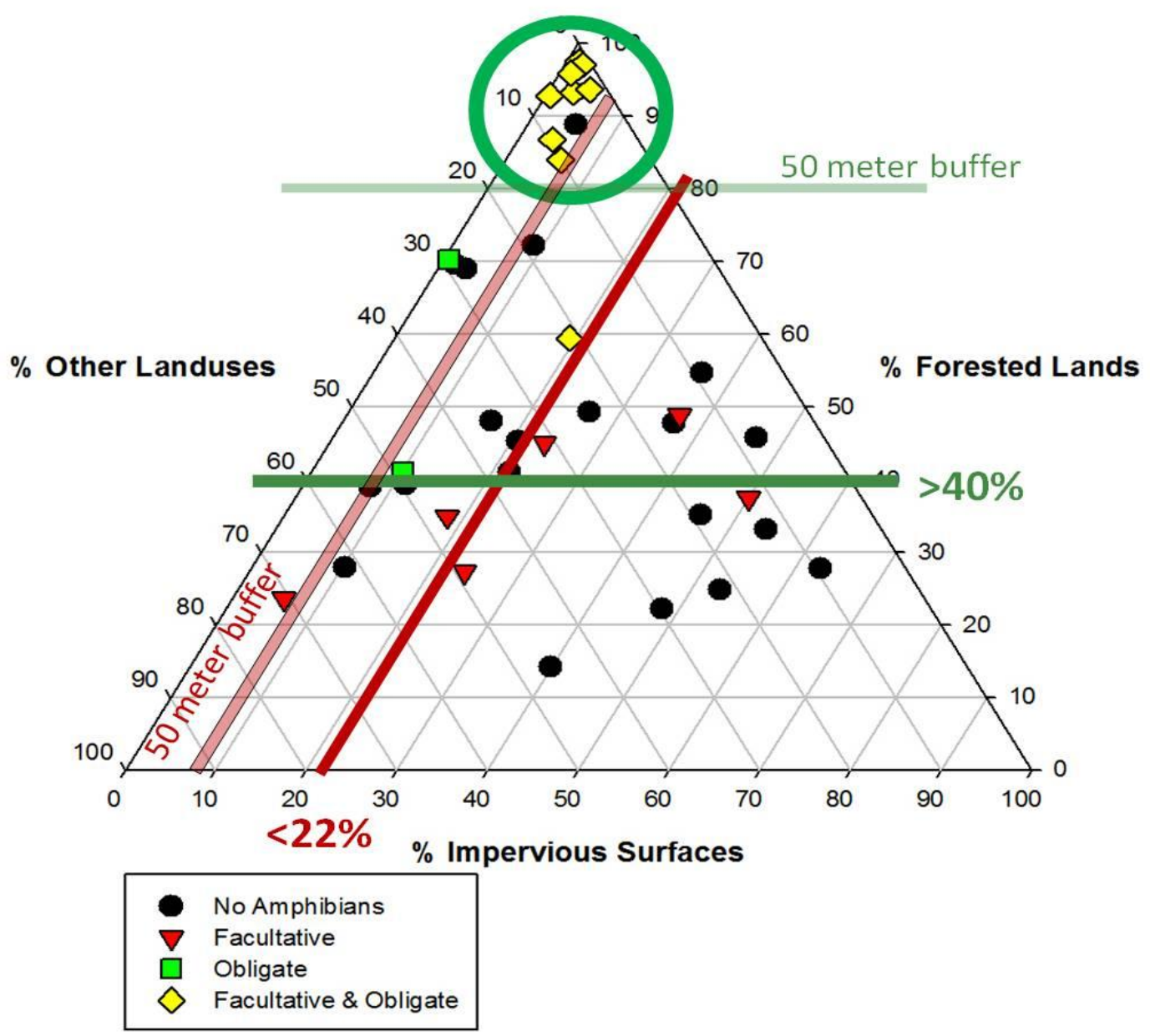

Figure 18 - Land-use Ratios within the Surrounding Sub-watershed Graphed by Amphibian Groups Observed. This graph depicts the ratio of 3 groupings of land-uses for each site within the delineated sub-watershed from each site. The category 'Other Landuses' includes herbaceous vegetation, agriculture, silviculture, open water, and bare lands. This grouping might be considered as types of moderate disturbance and a median between forested habitats and highly-disturbed areas with impervious surfaces. The LiDAR-derived (5X5 meter resolution) land-use dataset was utilized for these graph. The shaded area contains all sites where obligate species were detected. Bolded lines and associated labels indicate thresholds of each land-use group for sites with obligate species. The circled area serves to indicate that while a few sites with obligate species had more varied land-uses in wider riparian buffer zones, the majority of sites with obligate species were in riparian networks with greater than $80 \%$ forested land and less than $8 \%$ impervious surface regardless of the buffer width considered. 


\section{Statistical Analyses: Environmental Variables Significant to Amphibian}

\section{Occupancy}

\section{Non-Metric Dimensional Scaling}

A Non-Metric Dimensional Scaling (NMDS) analysis performed utilizing raw abundance numbers for each of the seven detected species resulted in an NMDS graph (Figure 19) showing sites with no amphibians closely clustered together to the left, while sites with both obligate and facultative species were clustered to the far right of the graph. Sites with only obligate species were located in a band to the left side, adjacent to the sites with no amphibians. Sites where facultative species were found were not well clustered but instead were spread out depending on the genus present (all sites with Plethadon species were located toward the bottom of the plot).

NMDS was then used to plot vectors representing all continuous environmental variables from the data set on top of the sites grouping. Only variables producing a p-value under 0.1 were included in the vector plot. This overlay resulted in a graph with a distinctive horizontal axis as well as 2 additional diagonal axes (Figure 20). 


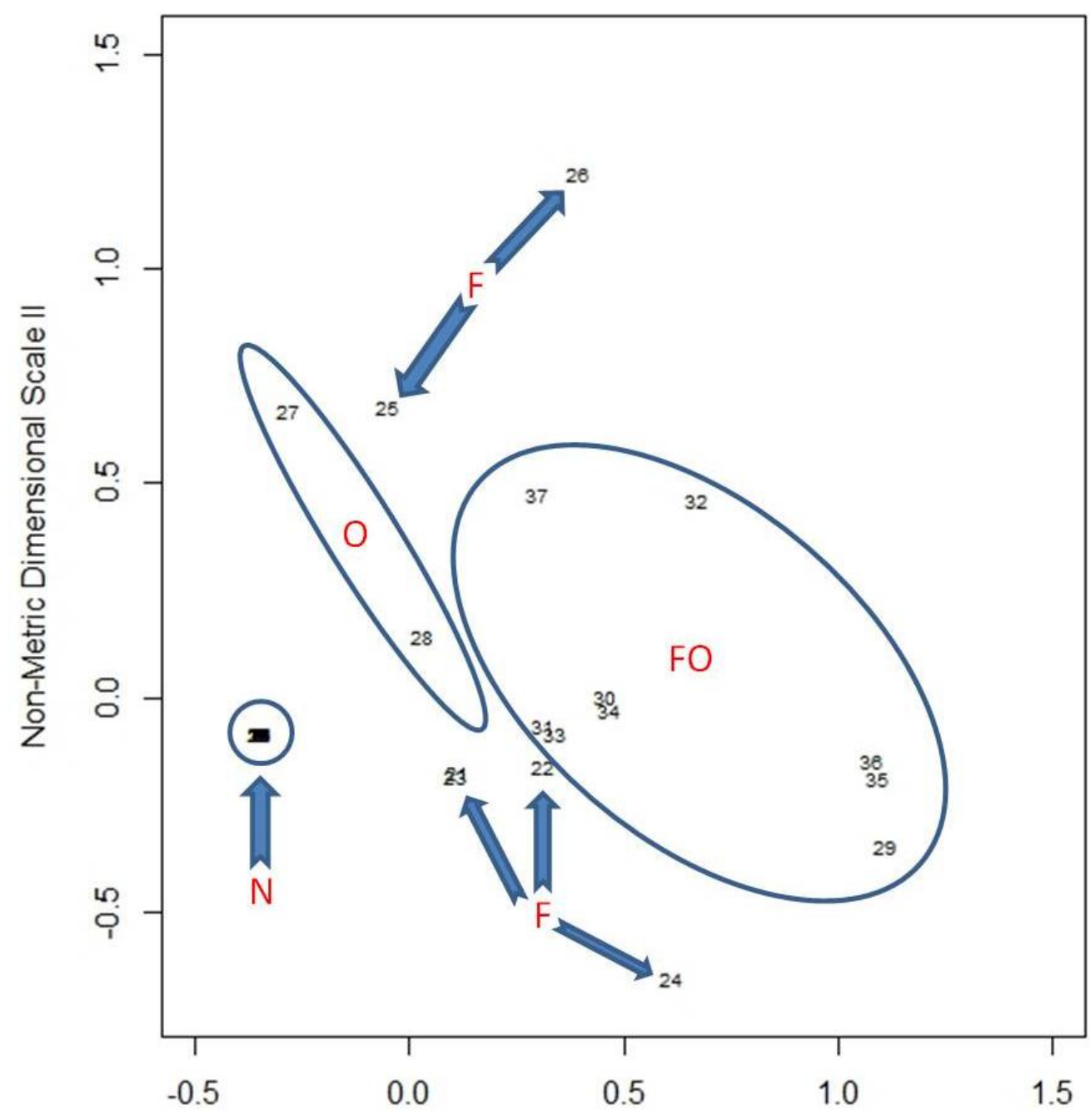

Non-Metric Dimensional Scale I

Figure 19 - Non-Metric Dimensional Scaling Graph of Species Abundance Data. This graph was constructed utilizing the abundance numbers for each detected species. The resultant figure grouped all of the sites with no amphibians closely together to the far left (marked with an 'N'), while all sites with both Faculative and Obligate species were located in a cluster to the far right (noted with a circle and the code 'FO'). Sites with only Obligate species (marked as 'O') appeared in a band adjacent to the sites with no amphibians, while sites with Facultative (marked with an ' $F$ ') were spread throughout depending on the relative abundance of the five facultative species detected (sites with high Plethadon abundances were all located in the lower part of the graph). 


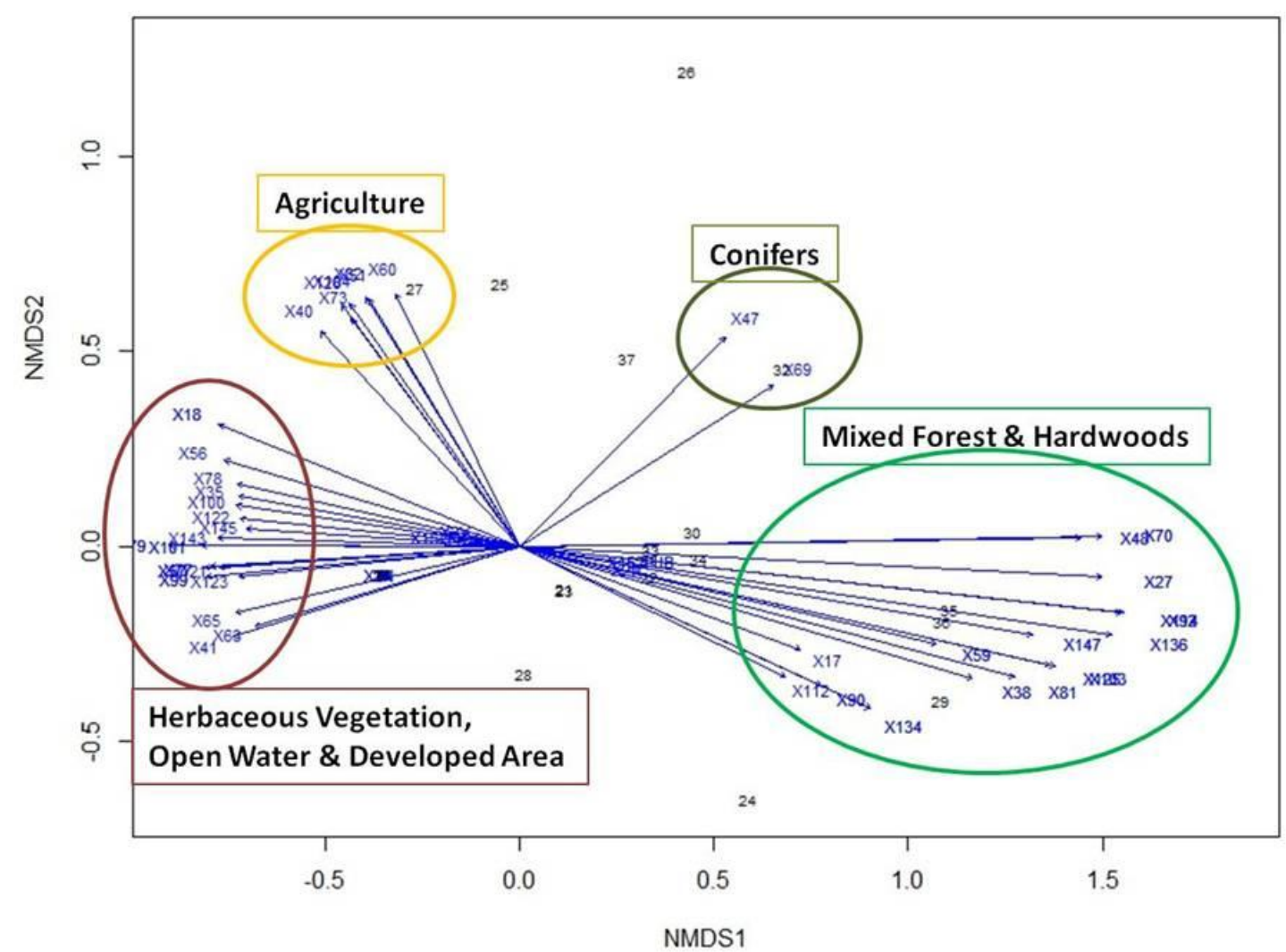

Figure 20 - Environmental Vector Non-Metric Dimensional Scaling Plot. Vectors representing all continuous numerical environmental variables were overlaid onto the plot of sites grouped by NMDS. Only vectors with $\mathrm{R}^{2}$ values that produced $\mathrm{p}$-values greater than 0.1 were included. This resulted in a clear horizontal axis with vectors representing Mixed Forest and Hardwood related variables running to the right and Herbaceous Vegetation, Developed Areas and Herbaceous Vegetation extending to the left. An additional two axes running diagonal across the plot were represented by variables associated with Agriculture and Coniferous forests.

Significant vectors represented in the overlay (Figure 20) were from four distinctive groups of environmental variables. Vectors extending to the right included those representing deciduous and mixed forest land-covers at various scales. Vectors extending diagonally up and to the right represented coniferous forest land-cover. Vectors pointing diagonally up and to the left included agricultural land-cover variables. Lastly, vectors extending horizontally to the left included environmental variables representing herbaceous vegetation cover, open water areas and developed/paved areas. In addition, this last group of vectors also included a variable 
measuring the 'Patchiness' of forested habitat, or more simply the proportion of edge-

forest habitat within the landscape surrounding each site. Table 6 (below) and

Appendix G list the vectors from the NMDS with significant explanatory power.

Table 5 - Environmental Predictors with Significant $\mathbf{R}^{\mathbf{2}}$ Values in NMDS Analysis. This table represents a list of all environmental variables that returned an $\mathrm{R} 2$ value significant to the $\mathrm{p}<0.05$ level during the Non-Metric Dimensional Scaling Analysis. Bolded variables represent variables of each unique land-use with the highest $\mathrm{R}^{2}$ values. These variables were included in further statistical tests.

\begin{tabular}{|l|l|l|r|}
\hline \multicolumn{5}{|c|}{ Significant Vectors (p<0.05) } \\
\hline Code & \multicolumn{1}{|c|}{ Variable Name } & P-value \\
\hline X92 & \% Mixed Forest (NLCD) (200 meters) & $\mathbf{0 . 6 3 3}$ & $<\mathbf{0 . 0 0 1}$ \\
\hline X114 & \% Mixed Forest (NLCD) (300 meters) & 0.627 & $<0.001$ \\
\hline X136 & \% Mixed Forest (NLCD) (Subwatershed) & 0.614 & $<0.001$ \\
\hline X27 & \% Mixed Forest (NLCD) (500 meters) & 0.583 & $<0.001$ \\
\hline X70 & \% Mixed Forest (NLCD) (100 meters) & 0.581 & $<0.001$ \\
\hline X48 & \% Mixed Forest (NLCD) (50 meters) & 0.540 & $<0.001$ \\
\hline X103 & \% Hardwoods (LC5) (200 meters) & $\mathbf{0 . 5 1 6}$ & $<\mathbf{0 . 0 0 1}$ \\
\hline X125 & \% Hardwoods (LC5) (300 meters) & 0.506 & $<0.001$ \\
\hline X147 & \% Hardwoods (LC5) (Subwatershed) & 0.465 & $<0.001$ \\
\hline X81 & \% Hardwoods (LC5) (100 meters) & 0.450 & $<0.001$ \\
\hline X38 & \% Hardwoods (LC5) (500 meters) & 0.381 & $<0.001$ \\
\hline X59 & \% Hardwoods (LC5) (50 meters) & 0.314 & 0.002 \\
\hline X134 & \% Deciduous Forest (NLCD) (Subwatershed) & $\mathbf{0 . 2 5 6}$ & $\mathbf{0 . 0 0 9}$ \\
\hline X79 & \% Herbaceous Short Veg (LC5) (100 meters) & $\mathbf{0 . 2 1 1}$ & $\mathbf{0 . 0 2 4}$ \\
\hline X90 & \% Deciduous Forest (NLCD) (200 meters) & 0.189 & 0.028 \\
\hline X18 & Forest Area Patchiness & $\mathbf{0 . 1 8 0}$ & $\mathbf{0 . 0 3 6}$ \\
\hline X101 & \% Herbaceous Short Veg (LC5) (200 meters) & 0.174 & 0.036 \\
\hline X57 & \% Herbaceous Short Veg (LC5) (50 meters) & 0.170 & 0.049 \\
\hline X99 & \% Sum Paved (LC5) (200 meters) & $\mathbf{0 . 1 7 0}$ & $\mathbf{0 . 0 4 8}$ \\
\hline X77 & \% Sum Paved (LC5) (100 meters) & 0.164 & 0.049 \\
\hline
\end{tabular}

The strongest distribution pattern observed from the Non-Metric Dimensional Scaling plots was one occurring along the primary horizontal axis. Sites with both facultative and obligate species were clumped on the far right side of the NMDS plot while sites without amphibians were tightly clustered at the far left. Sites with only 
facultative or obligate species were scattered in between and around these two groups. Variables related to the amount of deciduous and mixed forests, as well as those related to herbaceous vegetation and urbanization, were most influential in dividing the sites according to amphibian functional group presence. Variables relating to agricultural areas and coniferous forests were most significant in explaining the vertical variability of sites with facultative species. Only environmental variables representing landscape-scale factors were found to be significant in explaining species composition variations between sites. Landscape variables found to be significant through the NMDS were more strongly correlated with amphibian presence within the 100 to 200 meter riparian buffer scale than at other scales (See Table 5 and Appendix G).

\section{$\underline{\text { Logistic Regression of Significant Variables }}$}

Of the land-use variables analyzed with logistic regressions, four variables were found to be significantly correlated with both facultative and obligate species presence (\% Mixed Forest and \% Deciduous Forest within the 200-meter riparian buffer, \% Herbaceous Vegetation within the 100-meter riparian buffer and \% Open Development within the 50-meter buffer). Three additional land-use variables were found to be significantly related to obligate species presence but not facultative species presence (\% Deciduous Forest in the sub-watershed, \% Paved Surfaces in the 200-meter riparian buffer and \% Coniferous Forest in the 100-meter riparian buffer) (Table 6). 
Table 6- Logistic Regression Model Results for Obligate and Facultative Species Presence/Absence in Relation to Landscape-Scale Variables. This table represents the results of logistic regression models run with obligate species presence as the dependent variable and the significant variables identified by the NMDS model as the independent variables. Variables are ordered by the significance of each from the NMDS model. Significant $p$-values assigned to variables are marked with an asterix and bolded.

\begin{tabular}{|c|c|c|c|}
\hline $\begin{array}{l}\text { Var. } \\
\text { Code }\end{array}$ & $\begin{array}{c}\text { Land-Use Variable Included in } \\
\text { Model }\end{array}$ & $\begin{array}{c}\text { Obligate Presence } \\
\text { (Variable } \\
\text { Significance) }\end{array}$ & $\begin{array}{c}\text { Facultative Presence } \\
\text { (Variable } \\
\text { Significance) }\end{array}$ \\
\hline $\mathrm{X} 41$ & $\begin{array}{l}\text { \% Developed Land, Open Space } \\
\text { (NLCD) (50 meters) }\end{array}$ & $\operatorname{Pr}(>|\mathrm{z}|)=0.0344^{*}$ & $\operatorname{Pr}(>|\mathrm{z}|)=0.0439 *$ \\
\hline $\mathrm{X} 51$ & $\begin{array}{l}\% \text { Pasture Land (NLCD) }(50 \\
\text { meters) }\end{array}$ & $\operatorname{Pr}(>|z|)=0.276$ & $\operatorname{Pr}(>|z|)=0.504$ \\
\hline $\mathrm{X} 56$ & $\%$ Open Water (LC5) (50 meters) & $\operatorname{Pr}(>|z|)=0.0912$ & $\operatorname{Pr}(>|z|)=0.0728$ \\
\hline $\mathrm{X65}$ & $\begin{array}{l}\text { \% Developed Land, Medium } \\
\text { Intensity(NLCD) (100 meters) }\end{array}$ & $\operatorname{Pr}(>|z|)=0.0691$ & $\operatorname{Pr}(>|z|)=0.0521$ \\
\hline X69 & $\begin{array}{l}\text { \% Coniferous Forests (NLCD) } \\
(100 \text { meters) }\end{array}$ & $\operatorname{Pr}(>|\mathrm{z}|)=0.00266^{*}$ & $\operatorname{Pr}(>|z|)=0.123$ \\
\hline X79 & $\begin{array}{l}\text { \% Herbaceous Vegetation (LC5) } \\
\text { (100 meters) }\end{array}$ & $\operatorname{Pr}(>|z|)=0.00832 *$ & $\operatorname{Pr}(>|z|)=0.0372 *$ \\
\hline X92 & $\begin{array}{l}\% \text { Mixed Forests (NLCD) (200 } \\
\text { meters) }\end{array}$ & $\operatorname{Pr}(>|z|)=0.0399 *$ & $\operatorname{Pr}(>|\mathrm{z}|)=0.00988^{*}$ \\
\hline X99 & $\begin{array}{l}\text { \% Sum Paved (LC5) (200 } \\
\text { meters) }\end{array}$ & $\operatorname{Pr}(>|\mathrm{z}|)=0.0321 *$ & $\operatorname{Pr}(>|z|)=0.0557$ \\
\hline $\mathrm{X} 103$ & $\begin{array}{l}\text { \% Hardwoods (LC5) }(200 \\
\text { meters) }\end{array}$ & $\operatorname{Pr}(>|\mathrm{z}|)=0.00938 *$ & $\operatorname{Pr}(>|\mathrm{z}|)=0.00434 *$ \\
\hline $\mathrm{X} 126$ & $\begin{array}{l}\% \text { Agriculture (LC5) }(300 \\
\text { meters) }\end{array}$ & $\operatorname{Pr}(>|z|)=0.247$ & $\operatorname{Pr}(>|z|)=0.356$ \\
\hline $\mathrm{X} 134$ & $\begin{array}{l}\text { \% Deciduous Forests (NLCD) } \\
\text { (Sub-watershed) }\end{array}$ & $\operatorname{Pr}(>|\mathrm{z}|)=0.00874 *$ & $\operatorname{Pr}(>|z|)=0.088$ \\
\hline
\end{tabular}


Of the environmental variables measured at the Micro- and Meso-habitat scale, eight were found to be significantly correlated to obligate species presence. They included variables measuring water temperature and conductivity, coarse substrates, total cover, riffle meso-habitat, forest patch area and 'patchiness', and percent of impervious surfaces within the surrounding sub-watershed). Only one non-land-use variable, that relating to fine substrates, was found to be significantly correlated with facultative species presence (Table 7). 
Table 7 - Logistic Regression Model Results for Obligate and Facultative Species Presence/Absence in Relation to Micro/Meso-Scale Variables. This table represents the results of logistic regression models run with Facultative species presence as the dependent variable and the significant variables identified by the NMDS model as the independent variables. Refer to Table 3 for the names of the variables corresponding to each independent variable code. Significant p-values assigned to variables are marked with an asterix. †Although impervious surface area had a p-value below .05, it was not included in subsequent analyses due to the fact that fitted probabilities of 0 and 1 occurred during the modeling analysis.

\begin{tabular}{|c|c|c|c|}
\hline $\begin{array}{l}\text { Var. } \\
\text { Code }\end{array}$ & $\begin{array}{c}\text { Micro/Meso-Scale Variable } \\
\text { Included in Model }\end{array}$ & $\begin{array}{c}\text { Obligate Presence } \\
\text { (Variable } \\
\text { Significance) }\end{array}$ & $\begin{array}{c}\text { Facultative } \\
\text { Presence } \\
\text { (Variable } \\
\text { Significance) }\end{array}$ \\
\hline $\mathrm{X} 1$ & Canopy Density (\% Cover) & $\operatorname{Pr}(>|z|)=0.562$ & $\operatorname{Pr}(>|z|)=0.516$ \\
\hline $\mathrm{X} 4$ & Water Temperature $\left({ }^{\circ} \mathrm{C}\right)$ & $\operatorname{Pr}(>|\mathrm{z}|)=0.00839 *$ & $\operatorname{Pr}(>|z|)=0.133$ \\
\hline $\mathrm{X} 5$ & Water Conductivity $(\mu S)$ & $\operatorname{Pr}(>|z|)=0.0058^{*}$ & $\operatorname{Pr}(>|z|)=0.648$ \\
\hline X6 & \% Fine Substrate w/in Transect & $\operatorname{Pr}(>|z|)=0.0687$ & $\operatorname{Pr}(>|\mathrm{z}|)=0.0348 *$ \\
\hline $\mathrm{X} 7$ & $\begin{array}{l}\text { \% Coarse Substrate w/in } \\
\text { Transect }\end{array}$ & $\operatorname{Pr}(>|z|)=0.02 *$ & $\operatorname{Pr}(>|z|)=0.0755$ \\
\hline $\mathrm{X} 8$ & $\%$ Bedrock Substrate w/in Transect & $\operatorname{Pr}(>|z|)=0.402$ & $\operatorname{Pr}(>|z|)=0.557$ \\
\hline $\mathrm{X} 9$ & Total Cover Objects & $\operatorname{Pr}(>|\mathrm{z}|)=0.00308^{*}$ & $\operatorname{Pr}(>|z|)=0.408$ \\
\hline $\mathrm{X} 10$ & $\%$ Run Mesohabitat w/in Transect & $\operatorname{Pr}(>|z|)=0.105$ & $\operatorname{Pr}(>|z|)=0.619$ \\
\hline $\mathrm{X} 11$ & $\begin{array}{l}\text { \% Riffle Mesohabitat w/in } \\
\text { Transect }\end{array}$ & $\operatorname{Pr}(>|\mathrm{z}|)=0.0131 *$ & $\operatorname{Pr}(>|z|)=0.427$ \\
\hline $\mathrm{X} 12$ & $\%$ Pool Mesohabitat w/in Transect & $\operatorname{Pr}(>|z|)=0.246$ & $\operatorname{Pr}(>|z|)=0.758$ \\
\hline $\mathrm{X} 13$ & Maximum Pool Depth (cm) & $\operatorname{Pr}(>|z|)=0.293$ & $\operatorname{Pr}(>|z|)=0.392$ \\
\hline $\mathrm{X} 15$ & Downstream to Road (m) & $\operatorname{Pr}(>|z|)=0.0619$ & $\operatorname{Pr}(>|z|)=0.448$ \\
\hline $\mathrm{X} 16$ & Closest Road (m) & $\operatorname{Pr}(>|z|)=0.12$ & $\operatorname{Pr}(>|z|)=0.575$ \\
\hline $\mathrm{X} 17$ & Patch Area $\left(\mathrm{km}^{2}\right)$ & $\operatorname{Pr}(>|\mathrm{z}|)=0.00646^{*}$ & $\operatorname{Pr}(>|z|)=0.152$ \\
\hline $\mathrm{X} 18$ & $\begin{array}{l}\text { Patchiness (Patch } \\
\text { Perimeter/Area) }\end{array}$ & $\operatorname{Pr}(>|z|)=0.0081 *$ & $\operatorname{Pr}(>|z|)=0.113$ \\
\hline $\mathrm{X} 150$ & $\begin{array}{l}\text { Impervious Surface }(\% \text { of } \\
\text { Watershed })\end{array}$ & $\operatorname{Pr}(>|\mathrm{z}|)=0.022 *$ & $\operatorname{Pr}(>|z|)=0.0876$ \\
\hline $\mathrm{X} 151$ & $\begin{array}{l}\text { Impervious Surface Area w/in } \\
\text { Watershed }\end{array}$ & $\operatorname{Pr}(>|z|)=0.0494 \dagger$ & $\operatorname{Pr}(>|z|)=0.618$ \\
\hline
\end{tabular}


Overall, the results of the logistic regression models created with obligate species presence as the dependent variable indicated that seven land-use variables are significant predictors as well as eight variables at the meso- and micro-habitat scales, totaling 15 significant variables. Facultative species presence was only significantly predicted by five variables, four of them being at the landscape scale and only one being at the micro-habitat scale. Both obligate and facultative species presence were significantly predicted by measures of forested land, herbaceous vegetation and urbanized areas in the surrounding landscape. Neither the variables related to agricultural land-use nor those related to areas of open water were significantly correlated with either obligate or facultative species presence. The significance of each model as a whole, as well as goodness-of-fit measures (recorded as $\mathrm{R}^{2}$ values), was recorded and is included in Appendix $\mathrm{H}$.

Estimates and associated standard errors of logistic regression models for each significant variable indicated that obligate species presence was most strongly and negatively related to Forest Patchiness; measures of developed areas and herbaceous vegetation also had strong negative influences on obligate species presence. Obligate species occupancy was most positively related to measures of forested areas in the surrounding sub-watershed, particularly areas of mixed forest within the 200-meter riparian buffer (Figure 21). Facultative species presence was most negatively influenced by herbaceous vegetation within 100 meters of the upstream channel and most positively influences by mixed forest area within a 200 meter riparian buffer (Table 8). 


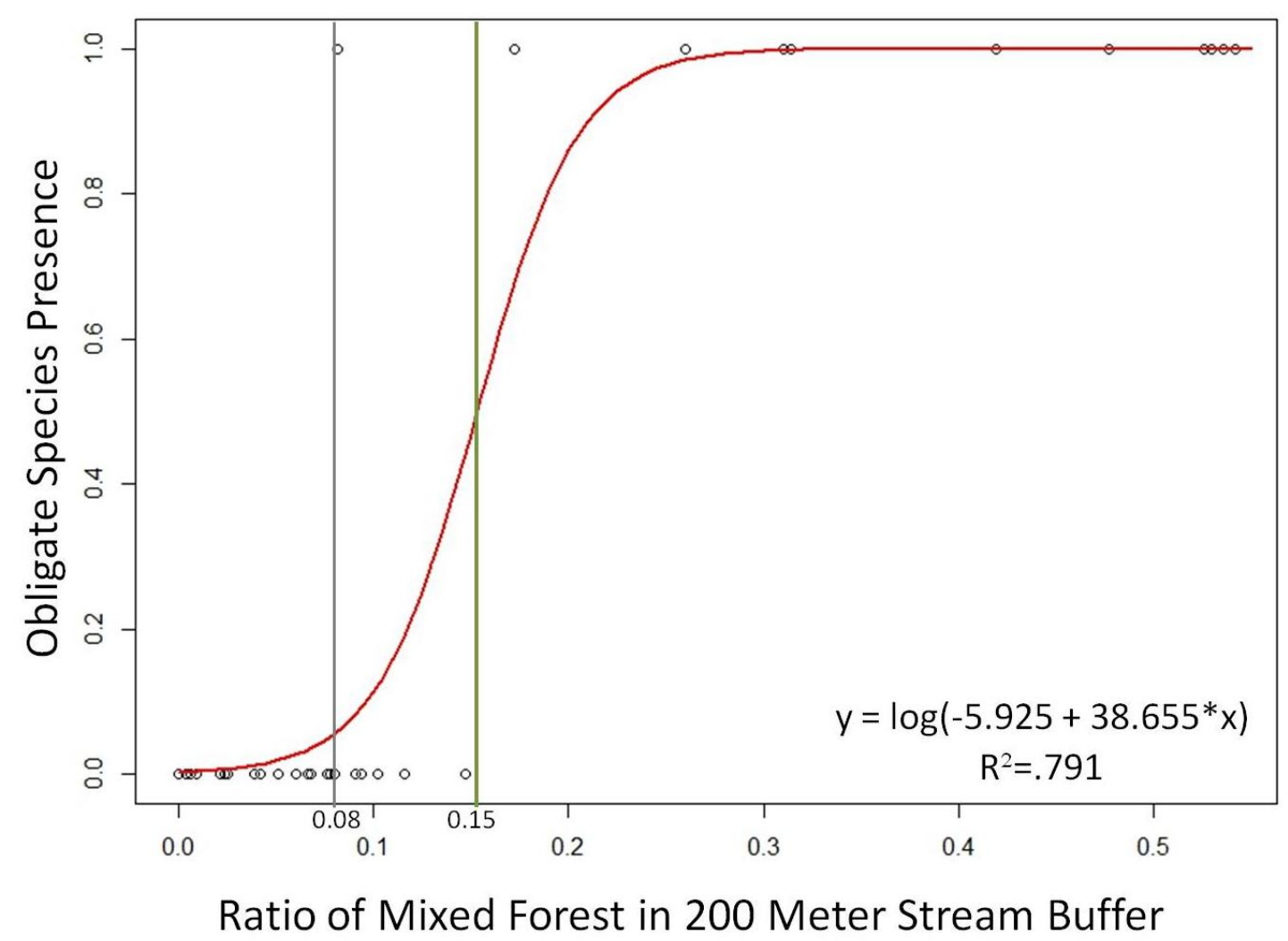

Figure 21 - Logistic Regression Result: Obligate Species Presence vs. Mixed Forest Area within the 200-meter Stream Buffer. This figure depicts the logistic regression between obligate species presence and the percentage of mixed forest within the 200-meter riparian buffer of the upstream stream network. The percentage of mixed forest explained $79 \%\left(\mathrm{R}^{2}=.791\right)$ of the variation in obligate species presence at the sampled sites. This represents the strongest correlation found between the environmental variables and the amphibian detections recorded in this study. 
Table 8 - Estimates and Standard Errors for Variables Tested with Logistic Regressions. The above table represents the positive or negative effect of each significant variable in relation to amphibian occupancy. Variables are listed in order from that with the most negative influence to that with the most positive influence on amphibian occupancy.

\begin{tabular}{|c|c|c|}
\hline Variable Name & Estimate & $\begin{array}{c}\text { Standard } \\
\text { Error }\end{array}$ \\
\hline \multicolumn{3}{|l|}{ Obligate Presence } \\
\hline Patchiness & -218.40 & \pm 82.48 \\
\hline \% Herbaceous Vegetation (LC5)(100 meters) & -42.44 & \pm 16.08 \\
\hline \% Open Development (NLCD)(50 meters) & -27.40 & \pm 12.95 \\
\hline$\%$ Sum Paved (LC5)(200 meters) & -26.24 & \pm 12.24 \\
\hline Water Temperature & -1.22 & \pm 0.46 \\
\hline Impervious Surface \% Cover & -0.16 & \pm 0.07 \\
\hline Conductivity & -0.023 & \pm 0.008 \\
\hline Total Cover & 0.007 & \pm 0.002 \\
\hline$\%$ Coarse Substrate & 0.05 & \pm 0.22 \\
\hline Adjacent Forest Patch Area & 0.21 & \pm 0.08 \\
\hline$\%$ Hardwoods (LC5)(200 meters) & 4.62 & \pm 1.78 \\
\hline \% Riffle & 5.09 & \pm 2.05 \\
\hline$\%$ Coniferous Forest (NLCD)(100 meters) & 8.94 & \pm 2.98 \\
\hline$\%$ Deciduous Forest (NLCD)(Sub-watershed) & 17.58 & \pm 6.70 \\
\hline \% Mixed Forest (NLCD)(200 meters) & 38.66 & \pm 18.82 \\
\hline \multicolumn{3}{|l|}{ Facultative Presence } \\
\hline \% Herbaceous Vegetation (LC5)(100 meters) & -12.91 & \pm 6.19 \\
\hline \% Open Development (NLCD)(50 meters) & -7.95 & \pm 3.95 \\
\hline$\%$ Fine Substrate & -0.04 & \pm 0.02 \\
\hline \% Hardwoods (LC5)(200 meters) & 6.05 & \pm 2.12 \\
\hline \% Mixed Forest (NLCD)(200 meters) & 11.88 & \pm 4.60 \\
\hline
\end{tabular}

\section{Contingency Tables for Categorical Variables}

Obligate species were significantly more likely to be present in streams that lacked fish populations and were located on public lands. Facultative species occupancy was not significantly related to fish presence but was positively related to 
public ownership of the land surrounding the stream. Neither obligate species nor facultative species were significantly influenced by the presence of crayfish (Table 9).

Table 9 - Fisher's Exact Test Results for Contingency Tables. Fisher's Exact Tests performed on the three categorical site variables supported three relationships. Obligate presence was significantly related to the presence of fish and land ownership, while Facultative species presence was only related to land ownership (significance is considered $\mathrm{p}<0.05$, as marked by an asterix in the table.

\begin{tabular}{|l|l|l|}
\hline $\begin{array}{l}\text { Fisher's Exact Test } \\
\text { Results }\end{array}$ & Obligate Presence & Facultative Presence \\
\hline Fish Presence (FP) & $\mathbf{p}=\mathbf{0 . 0 2 5}^{*}$ & $\mathrm{p}=0.087$ \\
\hline Crayfish Presence (CP) & $\mathrm{p}=0.409$ & $\mathrm{p}=1.000$ \\
\hline Land Ownership (LO) & $\mathbf{p}=<\mathbf{0 . 0 0 1 *}$ & $\mathbf{p}=\mathbf{0 . 0 3 8} *$ \\
\hline
\end{tabular}

\section{Occupancy Modeling}

All but one of the a priori models were run in the PRESENCE occupancy modeling program; the 'Urbanization: Secondary Effects' model for Facultative species presence was identical to the 'In-situ' model for facultative presence, so both were represented by the results of the 'In-situ' model. In addition to the variables included in the models listed in Table 11, three variables that may have impacted amphibian detection rates (air temperature and weather at the beginning and end of the sampling session) were included in all models for obligate species occupancy. No detection-related variables were included in facultative-species models due to the fact that they decreased the goodness-of-fit for all models. Models were ranked according to their AIC values, with the models of best-fit at the top of each list (Tables 10 and $11)$. 
Table 10 - Results from the Obligate Species Occupancy Models. These models represent the occupancy models used to predict the presence or absence of obligate stream amphibians. They are ranked according to AIC values with the best-fit models represented at the top of the list. The 'Urbanization: Secondary Effects' model was significantly better at predicting obligate presence than all other models.

\begin{tabular}{|c|c|c|c|c|c|c|}
\hline Obligate Model Theme & AIC & $\Delta \mathrm{AIC}$ & $\begin{array}{l}\text { AIC } \\
\text { Weight }\end{array}$ & $\begin{array}{l}\text { Model } \\
\text { Likelihood }\end{array}$ & $\begin{array}{l}\# \\
\text { Par }\end{array}$ & $\begin{array}{l}-2 * \text { Log } \\
\text { Likeliho } \\
\text { od }\end{array}$ \\
\hline $\begin{array}{l}\text { Urbanization: } \\
\text { Secondary Effects }\end{array}$ & 16 & -9.75 & 0.8914 & 1 & 8 & 0 \\
\hline In-situ variables & 22 & -3.75 & 0.0444 & 0.0498 & 11 & 0 \\
\hline Forest Area & 22 & -3.75 & 0.0444 & 0.0498 & 11 & 0 \\
\hline Watershed Variables & 26 & 0.25 & 0.006 & 0.0067 & 13 & 0 \\
\hline Mesohabitat Variables & 26.49 & 0.74 & 0.0047 & 0.0053 & 7 & 12.49 \\
\hline Moderate Development & 26.49 & 0.74 & 0.0047 & 0.0053 & 7 & 12.49 \\
\hline $\begin{array}{l}\text { Most Predictive \& } \\
\text { Unique }\end{array}$ & 28 & 2.25 & 0.0022 & 0.0025 & 14 & 0 \\
\hline Urbanization & 34.63 & 8.88 & 0.0001 & 0.0001 & 8 & 18.63 \\
\hline Universal Model & 44 & 18.25 & 0 & 0 & 22 & 0 \\
\hline Null Model & 49.03 & 23.28 & 0 & 0 & 2 & 45.03 \\
\hline
\end{tabular}

Obligate species occupancy was best predicted by a sub-set of variables related to potential secondary impacts of urbanization. The parameters chosen to be included in this model included measured factors previously observed to have been impacted by urban development (water temperature and conductivity (Miller et al., 2007; Orser and Shure, 1972), stream substrate due to scouring or sedimentation (Welsh Jr. and Ollivier, 1998; Orser and Shure, 1972; Riley et al., 2005)). In addition, models including In-situ variables and variables related to forest land-use ranked second, though the goodness-of-fit for both these models registered significantly below that of the 'Urbanization: Secondary Effects' model. Overall, variables related to the physical state of the stream were most important in predicting 
the presence of stream-obligate amphibians (particularly Pacific Giant salamanders)

followed by the extent and contiguousness of the riparian forest.

Table 11 - Results from the Facultative Species Occupancy Models. These models represent the occupancy models used to predict the presence or absence of facultative stream amphibians. They are ranked according to AIC values with the best-fit models represented at the top of the list. Four models are grouped closely at the top of this table and represent the best-fit models. Because the AIC values for these models are within 2 AIC units of one another, it is difficult to distinguish them from each other as they all have substantial levels of empirical support (MacKenzie et al., 2006).

\begin{tabular}{|c|c|c|c|c|c|c|}
\hline $\begin{array}{c}\text { Facultative Model } \\
\text { Theme }\end{array}$ & AIC & $\Delta \mathrm{AIC}$ & $\begin{array}{l}\text { AIC } \\
\text { Weight }\end{array}$ & $\begin{array}{l}\text { Model } \\
\text { Likelihood }\end{array}$ & $\begin{array}{l}\# \\
\text { Par }\end{array}$ & $\begin{array}{l}\text {-2*Log } \\
\text { Likeliho } \\
\text { od }\end{array}$ \\
\hline Watershed Variables & 34.78 & 0 & 0.3451 & 1 & 6 & 22.78 \\
\hline Universal Model & 35.68 & 0.9 & 0.2201 & 0.6376 & 8 & 19.68 \\
\hline $\begin{array}{l}\text { Most Predictive \& } \\
\text { Unique }\end{array}$ & 35.97 & 1.19 & 0.1904 & 0.5516 & 6 & 23.97 \\
\hline Forest Area & 36.25 & 1.47 & 0.1655 & 0.4795 & 4 & 28.25 \\
\hline In-situ variables & 37.75 & 2.97 & 0.0782 & 0.2265 & 3 & 31.75 \\
\hline Urbanization & 48.39 & 13.61 & 0.0004 & 0.0011 & 3 & 42.39 \\
\hline Moderate Development & 49.31 & 14.53 & 0.0002 & 0.0007 & 3 & 43.31 \\
\hline Mesohabitat Variables & 50.65 & 15.87 & 0.0001 & 0.0004 & 3 & 44.65 \\
\hline Null Model & 53.96 & 19.18 & 0 & 0.0001 & 2 & 49.96 \\
\hline $\begin{array}{l}\text { Urbanization: Secondary } \\
\text { Effects }\end{array}$ & - & - & - & - & - & - \\
\hline
\end{tabular}

Four of the models constructed to predict facultative species occupancy had low AIC values that were not significantly different from each other. The minimal variation in goodness-of-fit between these four models meant that all four models had strong, significant empirical support. These models included the 'Watershed Variable' model, the universal model, the 'Most Predictive and Unique' model and the 'Forest Area' model. All of these models included at least two environmental variables and all of these models included the variable representing the proportion of 
hardwood forests within 200 meters of the stream. The top three models all included the variable defining herbaceous vegetation within 100 meters of the stream as well. Concerning individual variables, the combined model weight ( AIC Weight) for models including the variable measuring hardwood forests within 200 meters was .9211 , while the combined weight for models containing the variable representing Herbaceous Vegetation within 100 meters was .7566 (Appendix J). Models including only one predictive variable ranked lowest. Overall, deciduous forest area adjacent to the stream channel was most significant in predicting facultative species presence. 


\section{DISCUSSION}

\section{Overall Conclusions from Statistical Analyses}

The results of these analyses have highlighted the complexity of amphibian ecology and ecology in general. Landscape variables were most significant in explaining amphibian community composition, though different land-use types were most influential at differing distances from the stream network. This complexity is particularly evident in the NMDS plot, which indicates that the presence of newts and frogs is positively influenced most significantly by the presence of coniferous forest, while Plethadon species are positively associated with deciduous and mixed forests and negatively associated with agricultural areas. In addition, Pacific Giant salamander occupancy, as well as occupancy of both Plethadon species of salamander, is positively influenced by deciduous and mixed forest cover (Figure 22).

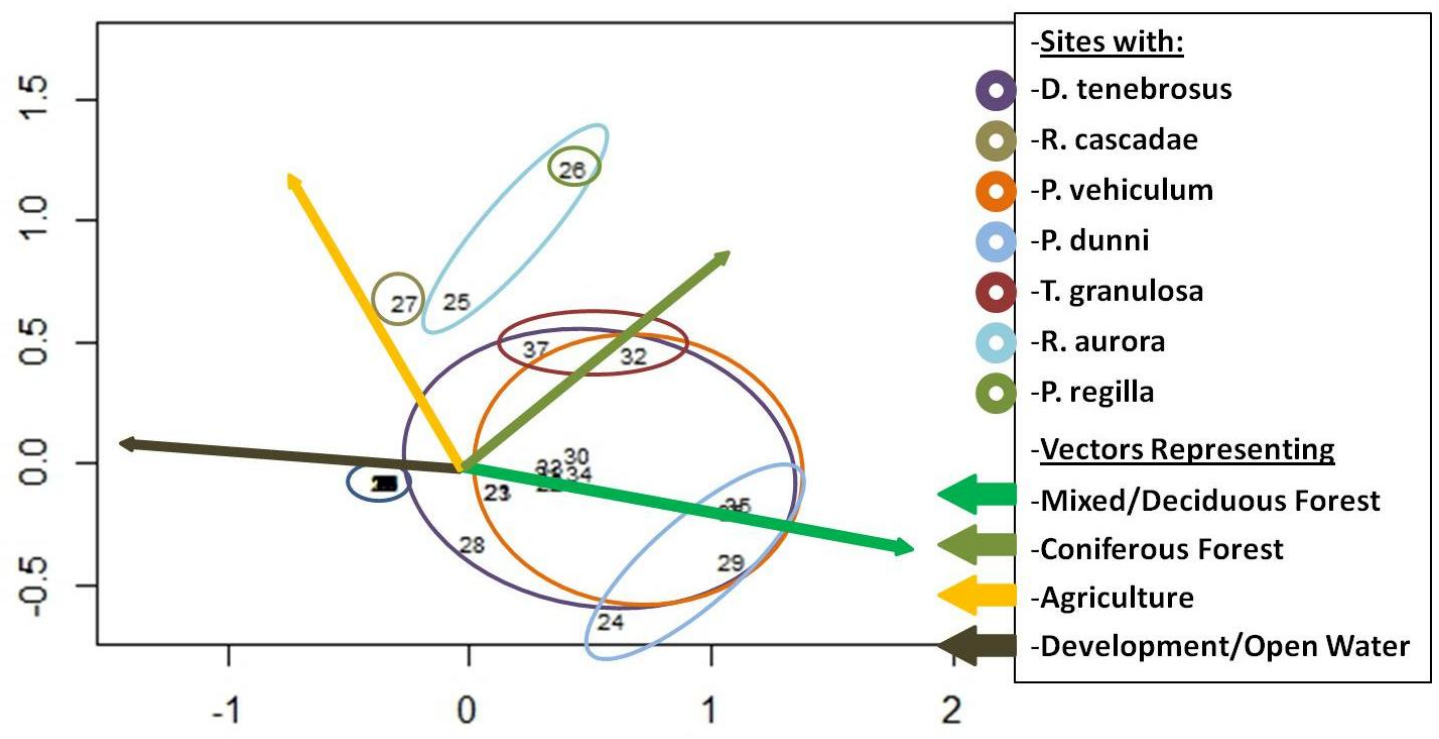

Figure 22 - NMDS Species Groupings and Summarized Vector Axes. Represented above is the NMDS site plot with circles highlighting groups of individual species. Overlain with that is the generalized vectors represented in Figure 19. This figure was constructed to aid in the analysis of factors that may be influencing the presence/absence of individual species rather than the functional groups used for the majority of the statistical analyses. 
The observed variability in significant occupancy predictors between each species indicates an inherent difficulty in preserving stream-associated amphibian communities. While preventing agricultural development of riparian areas may be most necessary to preserving Plethadon salamander populations, preventing urban development of riparian communities seems most necessary to preserving Dicamptadon communities. The only common thread for all species seems to be a preservation of forests around streams, though even then it is necessary to preserve forests of different compositions for different species. As many have suggested, the heterogeneity of a stream is essential for the broad array of species that utilize these freshwater aquatic systems (Wissmar and Beschta, 1998; Fausch et al., 2002). Similarly, it would seem that heterogeneity is required in the riparian buffer as well.

\section{Relating Results to the Hypotheses}

As predicted, stream amphibian populations were negatively affected by increasing levels of development (Table 8). It is difficult to separate the types of development analyzed into gradients of severity, but if herbaceous vegetation may be interpreted as a proxy for forms of moderate development (in the form of landscaping practices, for instance) and impervious surfaces as a proxy for intense development, then the data do not support the hypothesis that more intensive forms of development would more negatively affect stream amphibians. On the contrary, herbaceous vegetation was a greater negative influence on stream-associated amphibian presence than any other variable, perhaps because this disturbance is more common. 
Though conclusions about abundances are not possible from this study, facultative species presence was less negatively influenced by development of the surrounding landscape than obligate species presence. This is indicated by the relative estimates calculated for each variable in the logistic regressions (see Table 9). In addition, riparian sites with amphibians had greater proportions of surrounding forest area, lower water temperatures, lower water conductivity and higher proportions of coarse substrate. However, the latter three variables were only found to be significant predictors of obligate amphibian presence, indicating that the third hypothesis was correct in relation to obligate stream species but not facultative species.

\section{Amphibian Habitat Requirements}

\section{$\underline{\text { In-Situ Variables }}$}

Many of the in-situ habitat variables followed a clear pattern when comparing sites where no amphibians were present to sites where individuals of either functional group were detected. Sites with obligate amphibian species had lower average water temperatures and lower average water conductivity than sites without amphibians. Though these measurements were only taken during one site-visit and merely provide a snap-shot of the overall water quality of each site, these observations are in agreement with past literature suggesting that higher temperatures and conductivity levels are detrimental to amphibian populations (Welsh Jr. and Lind, 2002; Miller et al., 2007). Sites with obligate species also had a greater number of cover objects on 
average and a greater proportion of coarse substrate. This observation is also in agreement with past studies indicating a positive association of stream amphibians with coarser stream substrate (Davic and Orr, 1987; Corn and Bury, 1989; Parker, 1991) and conversely a negative association with fine substrates (Stoddard and Hayes, 2005; Ashton et al., 2006). The significance of these variables to obligate stream amphibians was confirmed through the logistic regressions and occupancy modeling. The averages for these in-situ parameters at sites where facultative species were detected fell in between the averages of sites with obligates and those without amphibians. Statistical analysis showed these variables to be insignificant to facultative species.

\section{$\underline{\text { Biogeographic Variables }}$}

This study is unique in its assessment of landscape patterns at various distances from the stream network. Though many studies have characterized amphibian populations in relation to land-use patterns in the surrounding watershed (Wilson and Dorcas, 2003; Riley et al., 2005; Price et al. 2006), specific buffer areas (Knutson et al., 1999; Barrett and Guyer, 2008) or width of forested riparian buffer zones (Vesely and McComb, 2002; Stoddard and Hayes, 2005; Miller et al., 2006), few take into account land-use composition at graduated riparian buffer distances. Past studies that have accounted for land-use at multiple scales, such as that conducted by Lehtinen et al. (1999), have focused on wetland amphibians. By accounting for land-uses at staggered distances from the stream network, this study 
was able to draw conclusions about the impacts of certain types of land-use on the stream environment and associated amphibian communities.

Ratios of land-uses followed a similar pattern to that of finer-scale variables. Percentages of developed and agricultural land-uses were lower for sites with obligate stream amphibians while percentages of forested land-use categories were higher (see Figure 23). In addition, tertiary graphs included in the Results section (Figures 1618) suggest a threshold of development in relation to obligate species presence. All but one site with obligate species present remained under the $10 \%$ Impervious Surface threshold throughout the outward progression of buffer distances. The one site that does occur in a watershed with more than $10 \%$ impervious surface only has more than $10 \%$ imperviousness outside of the 100 meter buffer and never has more than $20 \%$ imperviousness regardless of buffer width.

These observations are also in agreement with past studies, which have indicated a drastic decline in amphibian populations when developed areas approach a certain percentage of a watershed (20\% 'disturbed habitat' for Eurycea cirrigera (Willson and Dorcas, 2003), 8\% ‘development' for Stream-Associated amphibians in California (Riley et al., 2005)). However, the question remains as to how to quantify development and/or urbanization; tertiary graphs in this paper utilized a highresolution estimate of impervious surfaces while many studies have used more general classifications of disturbance, such as that measured in the NLCD dataset also utilized in this study. Defining land-use thresholds may provide a useful tool for 
amphibian conservation, but the definitions of land-uses must be standardized to make these thresholds more uniformly applicable.

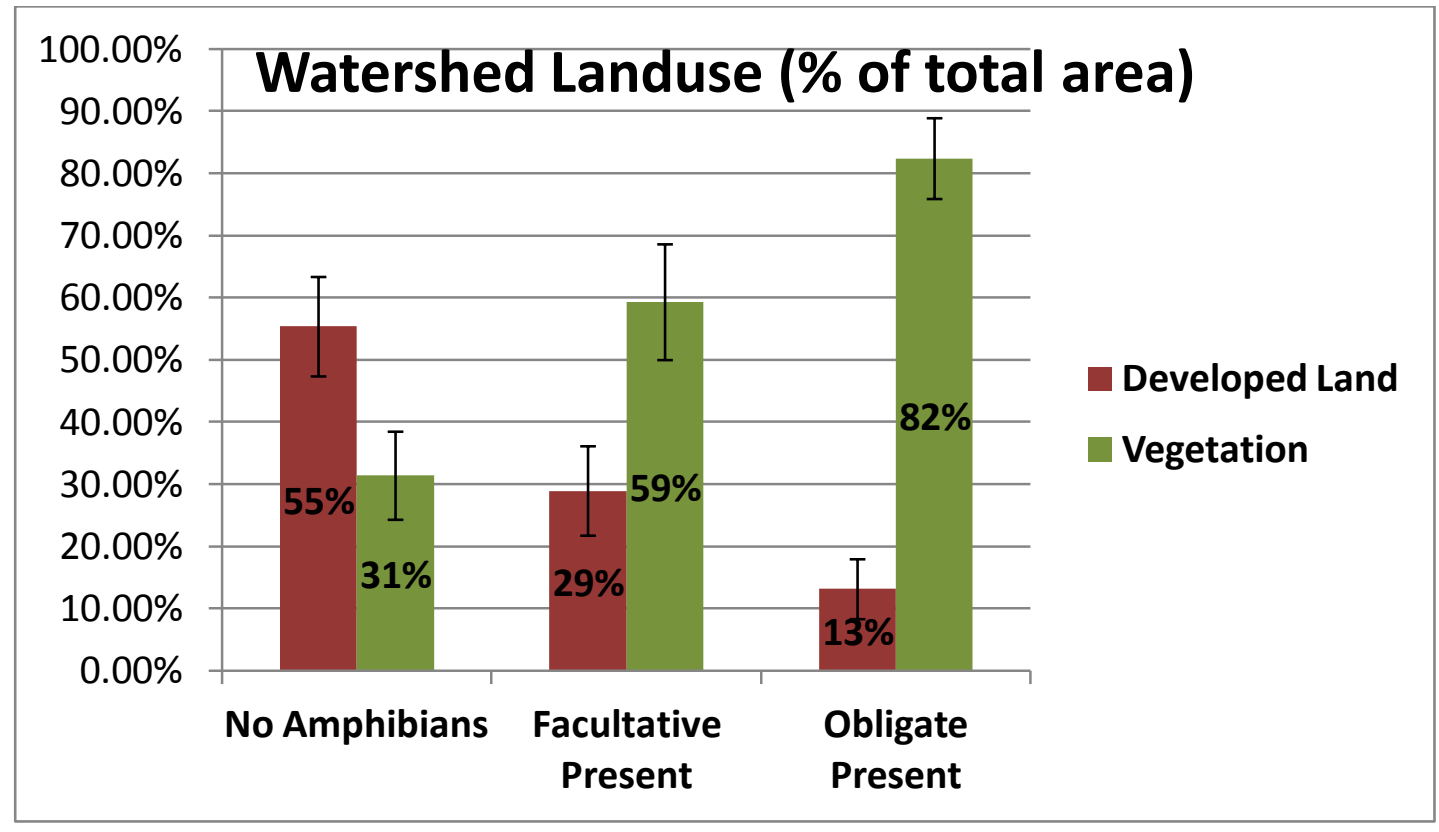

Figure 23 - Ratios of Land-use at the Sub-watershed Scale - This graph depicts the percentages of two categories of land-use (vegetated areas and developed areas, as defined by the NLCD 2006 database). Sites with obligate species had higher percentages of vegetated areas and lower percentages of developed areas in the surrounding landscape when compared to site with facultative species or no amphibians.

\section{Presence/Absence Modeling Trends and Anomalies}

Though many studies have shown that forested riparian areas directly correlate with amphibian abundances and diversity (Vesely and McComb, 2002), few have dealt more specifically with the composition of riparian buffers in relation to amphibian populations. While overall measures of surrounding land-uses are helpful in identifying the positive or negative influence of development, identifying the scales at which these variables influence amphibian occupancy is essential for amphibian 
conservation. NMDS modeling suggested that most of the variation in stream amphibian community composition was explained by the ratio of forested lands versus areas composed of herbaceous vegetation or more heavily developed areas. The scale at which these land-use variables had the greatest influence was most often between the 100 and 200 meter stream-buffer ranges. This seems to be a strong endorsement for previous studies that have indicated that large stream buffers ranging from 93 to 300 meters are needed to preserve amphibian populations (Semlitsch and Bodie, 2003; Crawford and Semlitsch, 2005; Olson et al., 2007).

Other interesting factors revealed by the NMDS plot include the significance of open water area within the horizontal axis and the separation of vectors representing coniferous forest land-cover from those representing deciduous and mixed forests. The significance of open-water in the surrounding landscape was most likely related to the detection of three pond-breeding species (Rough-skinned newt, Pacific tree frog, Northern red-legged frog). The indication that variables related to coniferous forest influence amphibian species differently than those related to other types of forest proves more curious. The groupings of individual species that can be observed in Figure 22 may indicate an importance of coniferous forest to the three pond-breeding species listed above. Pacific tree-frogs have been associated specifically with Douglas-fir forests of varying successional stages and Northern Redlegged frogs are known to be more abundant in moist coniferous forests (Lannoo, 2005). However, Rough-skinned newts are thought to have little preference for a specific habitat, ranging between coniferous forests, redwood forests, oak-woodlands 
and grasslands (Lannoo, 2005). Considering the fact that these three species are more mobile than the other two facultative species detected in this study, especially during the juvenile life-stage (see Table 2), this indicates a need for intact upland forest areas that provide dispersal corridors.

While NMDS was helpful in determining overall trends, logistic regressions and occupancy modeling allowed the identification of significant variables specific to each stream-amphibian functional group. Of those variables identified by logistic regressions, five were found to be significant for both obligate and facultative species: Mixed Forest and Hardwoods within 200 meters of the stream network, Herbaceous Vegetation within 100 meters of the stream network, low-intensity development within 50 meters of the stream network and the type of land-ownership surrounding the sampled stream segment. Interestingly, all of these variables are inherently correlated with one another, with the presence of one land-use excluding another. In addition, whether the surrounding land is publicly or privately owned undoubtedly impacts the existent type of land-use. This would indicate that just as the importance of numerous ecological processes varies between different spatiotemporal scales in relation to fish populations (Fausch et al., 2002), the same holds true for amphibians.

Low detection and abundance numbers made it necessary to group obligate and facultative species together for analysis. The inclusion of many different species with varying environmental requirements may have caused tests not to be sensitive enough to detect important correlates for individual species represented by the 
facultative species group. However, the five variables that were found significant to facultative species may be more representative of environmental requirements for diverse facultative stream amphibian community. On the other hand, those variables identified as significant for obligate species are most likely significant in relation to the presence/absence of Pacific Giant salamanders due to the fact that all but one of the sites with obligate species were populated by Dicamptadon tenebrosus. Caution should be taken in assigning significance of these variables to the occupancy of Cascade Torrent salamanders due to low detection numbers.

It is worth noting that only one in-situ environmental variable was found significant in relation to facultative species presence, that representing the percentage of fine substrate within the sampled stream transect. Considering that no other variables measuring in-stream habitat characteristics were found to be significantly correlated to facultative species presence, the percentage of fine substrates may be indicative of a broader process impacting facultative species such as bank-side erosion, which could reduce stream-side habitat utilized by facultative species, or the elimination of in-stream macro-invertebrates and the subsequent loss of a food source for facultative species. Alternatively, fine sediments may simply be an indication of development in the surrounding landscape that is reducing surrounding habitat availability (Orser and Shure, 1972; Welsh Jr. and Ollivier, 1998; Riley et al., 2005). 
Legacy Effects: Landscape Patterns Shaping Streams

The results of the occupancy models constructed in this study indicated that in-situ variables more accurately predict obligate amphibian presence than variables measuring the environment at larger scales. However, as previously cited, stream conditions are subject to landscape patch dynamics that might alter hydrologic processes, microclimates and energy inputs (Welsh Jr. and Lind, 2002). The predictive power of land-use statistics in relation to obligate stream amphibian presence may be hindered by legacy effects, or continuing impacts on stream systems due to landscape alterations in past generations. These legacy effects may complicate correlations between in-stream conditions and landscape patterns by adding temporal variations. For instance, stream amphibians in the Oregon Coast Range have been negatively affected by sedimentation of stream channels caused by logging operations for up to 50 years post-disturbance (Ashton et al., 2006) despite reforestation of adjacent areas. In this instance, significant areas of riparian forest would not account for elimination of lotic habitat by past management practices. Effective occupancy modeling for lotic amphibians may require current as well as historical landscape variables.

\section{Amphibian Conservation and Future Studies}

If the survey performed for this study might be seen as a characterization of streams around the Portland-Vancouver region, it suggests that many of the streams in the region do not represent suitable habitat for stream-obligate species. Obligate 
species were detected at less than a third of the sites surveyed. Facultative species were detected at only a few more sites than obligates, suggesting that riparian refugia in the region are only slightly better suited for these species. Analysis showed that stream-associated amphibians were more likely to occupy sites located on public properties, specifically park lands. Past studies have also shown biodiversity to significantly vary among lands under different types of ownership, with higher diversity being detected on areas under public or mixed ownership (Lovett-Doust and Kuntz, 2001). Current riparian conservation regulations for private properties in the region may not be sufficient, or are alternatively not sufficiently enforced, to conserve stream amphibians.

All four stream-obligate species with ranges in the Portland-Vancouver region are commonly associated with forested headwater streams, preferring streams of higher gradients and consolidated substrates (Lannoo, 2005). In this study, urban refugia in which obligate amphibians were detected encompassed stream channels characterized by coarse substrate and abundant riffle meso-habitat. In addition, streams were well-shaded and generally shallow, maintaining cool water temperatures. These streams contained numerous objects suitable for concealing amphibians and few areas where bedrock was exposed (Figure 24). 


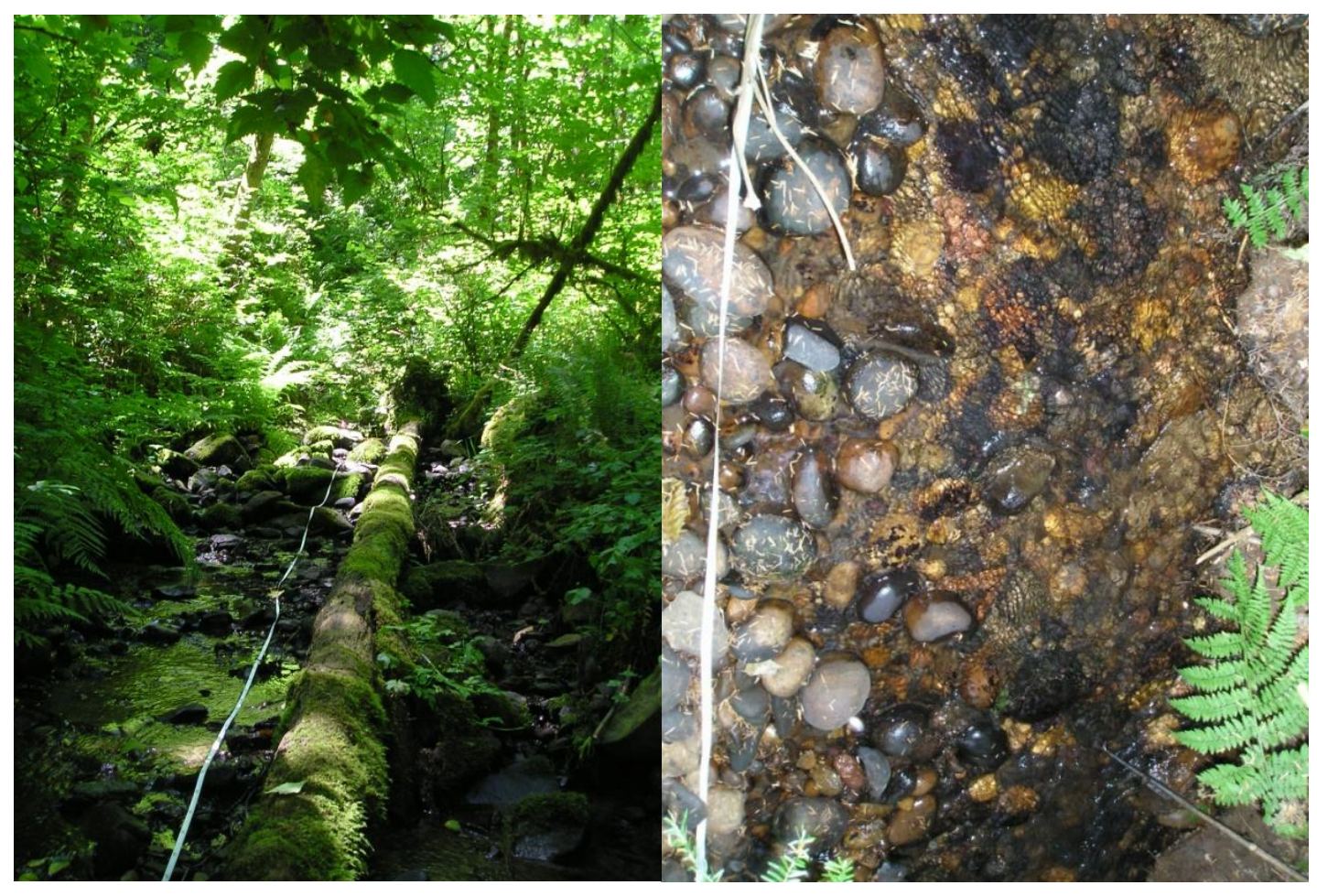

Figure 24 - Photographic Example of Stream Obligate Amphibian Habitat. These pictures depict some of the environmental conditions in which obligate stream species were encountered. Stream s where obligate species were detected had plentiful cover, usually in the form of coarse rocky stream substrate. In addition, these streams were in well-forested areas which shaded the stream and maintained cool water temperatures.

A primary issue concerning stream-amphibian conservation becomes how to regulate riparian areas such that the essential habitat qualities discussed above are maintained for local amphibian species. If herbaceous vegetation common in private yards exerts a strong negative influence on stream-amphibian occupancy when present within 100 meters of a stream channel and forested riparian areas represent a strong positive influence within 200 meters, riparian regulation that allows any development within a 200 meter riparian buffer area fails to adequately protect stream amphibians. As many of the development-constricting policies in Portland and surrounding cities only require riparian buffers of 5 to 7.5 meters (Ozawa and 
Yeakley, 2007), it is clear that these prohibitive policies fall short of maintaining the 50-200 meter buffers indicated as influential in this study. It is also necessary to recognize the importance of riparian buffers throughout the stream channel. Park areas surrounding streams are common throughout the Intertwine and include parks such as Tryon Creek State Natural Area, Marquam Nature Park and Arnold Park (Houck and Cody, 2011), all of which potentially provide adequate habitat for facultative species. However, these isolated riparian refugia offer no protection from upstream development. In addition, amphibian populations largely function as metapopulations, subject to cycles of localized extinctions and recolonizations. Isolation of breeding habitats due to loss of adjacent terrestrial habitat may result in genetic segregation and the prevention of recolonization by adjacent populations (Marsh and Trenham, 2001). Streams are complex, spatially continuous systems that must be managed as riverscapes and whole networks in order to preserve landscape processes that lotic fauna depend on (Swanson and Franklin, 1992; Wissmar and Beschta, 1998; Fausch et al., 2002).

While this survey may discount many streams in the urbanized Intertwine region (http://www.theintertwine.org) as insufficient habitat for stream amphibians, it also highlights the importance of forested areas, such as Forest Park, to these lotic species. Referring back to Figure 1, large swaths of forested land still exist with the region defined as the Intertwine. Conserving these forested refugia becomes essential to the preservation of remaining stream obligate species, especially areas that encompass entire headwater networks. The presence of Pacific Giant salamanders in 
all surveyed streams within Forest Park is encouraging and a testament to the benefit of valuing natural resources as past citizens (e.g. John Charles Olmsted) and organizations have advocated (e.g. City Club of Portland and the Committee of Fifty) (Houck and Cody, 2011).

Future studies would do well to further categorize the impacts of varying types of land-use at staggered distances from a stream network. In addition, it will be necessary to determine the impacts of different forms of development on individual species to develop more effective conservation strategies. It would also benefit conservation efforts to directly link specific types of land-use to the alterations in local habitat quality that most significantly affect target species, such as linking percentages of impervious surfaces to changes in water conductivity as done in past studies (Miller et al., 2007). To preserve regional stream amphibian communities for future generations, it will be necessary to inform and advance riparian-related policy with in-depth studies defining specific impacts on landscape development on streamassociated amphibians. 


\section{CONCLUSION}

Stream-associated amphibian communities within the Portland-Vancouver metropolitan region are shaped by the landscape that surrounds them. This study was able to assess the impacts of land-use at varying scales on regional stream environments and associated amphibian communities. While the presence of facultative stream species such as Western Red-backed and Dunn's salamanders were strongly determined by the land-use composition of riparian zones, obligate species like the Pacific Giant salamander were influenced more significantly by the physical stream environment. Both groups are influenced strongly by the extent of riparian forests throughout the stream-network in which they inhabit, particularly within 200 meters of the stream channel.

In 1936, Stanley Jewett catalogued the presence of 14 amphibian species in the Portland, Oregon region (Jewett, 1936). Recent studies have reaffirmed the presence of at least ten amphibian species in the greater Portland area (Holzer, 2009a; Holzer, 2009b). This study further confirmed the presence of six of these species within riparian refugia as well as a population of Cascade Torrent salamanders in the northern section of Clark County, Washington. As amphibian populations continue to decline worldwide, local amphibian surveys by organizations such as Metro and the City of Portland become an essential tool in monitoring populations and assessing the state of regional amphibians. Unfortunately, stream amphibians are currently excluded from most of these surveys. 
There remain a number of forested refuges within the region that may be capable of sustaining stream amphibian communities. However, amphibian populations largely function as metapopulations, subject to cycles of localized extinctions and recolonizations. In addition, the habitat requirements of the streamfacilitated amphibians in the Portland-Vancouver metropolitan region are not uniform. Identifying a network of parks and other forested riparian areas of various floral species assemblages, much like that defined as 'the Portland-Vancouver Intertwine region' (http://www.theintertwine.org), is essential to maintaining a robust and diverse stream amphibian population. In addition, headwater networks where stream-obligate species thrive must continue to be protected and/or restored.

Stream-associated amphibian communities are significantly influenced by the composition of the surrounding landscape (Price et al., 2010), much the same as the streams that they inhabit. Urbanization has proven to be particularly detrimental to stream amphibian populations, altering habitat suitability both in-stream and within riparian systems (Price et al., 2011). Maintaining forested riparian buffers may prove essential to conserving stream amphibians, but it is equally essential to define the scales at which to maintain them. In addition, riparian conservation cannot be the responsibility of a few landowners along a stream network. It must necessarily require the cooperation of all landowners along stream channels.

This study indicates that current regional riparian buffer regulations are not sufficiently conserving the stream habitats on which lotic amphibians depend. If stream amphibians are to be sustained, it will be necessary to provide riparian habitat 
at adequate scales for all of the regions amphibian species. In addition, riparian buffers throughout the stream network must be capable of maintaining the physical stream conditions required by obligate species, such as low water temperatures and adequate coarse substrate. To achieve these goals, riparian policies must be informed by research explicitly linking the effects of land-use at various scales to degradations in regional stream environments. 


\section{REFERENCES}

$\checkmark$ Alford, Ross A.; Richards, Stephen J. 1999. Global Amphibian Declines: A Problem in Applied Ecology. Annual Review of Ecology and Systematics Vol. 30, pp. 133-165

$\checkmark$ Alig, Ralph J.; Plantinga, Andrew J. 2004. Future Forestland Area: Impacts from Population Growth and Other Factors that Affect Land Values. Journal of Forestry, Vol. 102:8, pp. 19-24

$\checkmark$ Allan, J. David; Castillo, Maria M. 2007. Stream Ecology: Structure and Function of Running Waters. Second Edition. Springer Publishing, Dordrecht, The Netherlands

$\checkmark$ AMEC Environment and Infrastructure. 2011. Urban Tree Canopy Assessment. Prepared for the Department of Public Works, City of Vancouver, Washington, September 2011

$\checkmark$ Ashton, Donald T.; Marks, Sharyn B.; Welsh Jr., Hartwell H. 2006. Evidence of Continued Effects from Timber Harvesting on Lotic Amphibians in Redwood Forests of Northwestern California. Forest Ecology and Management, Vol. 221, pp. 183-193

$\checkmark$ Barrett, Kyle, Guyar, Craig. 2008. Differential Responses of Amphibians and Reptiles in Riparian and Stream Habitats to Land Use Disturbances in Western Georgia, USA. Biological Conservation, Vol. 141, pp. 2290-2300

$\checkmark$ Bartlett, R. D.; Barlett, Patricia P. 2009. Guide and Reference to the Amphibians of Western North America (North of Mexico) and Hawaii. University Press of Florida. Gainesville, Florida.

$\checkmark$ Bond, N. R.; Lake, P. S. 2003. Local Habitat Restoration in Streams: Constraints on the Effectiveness of Restoration for Stream Biota. Ecological Management \& Restoration Vol. 4:3, pp. 193-198

$\checkmark$ Booth, Derek B. 2005. Challenges and Prospects for Restoring Urban Streams: A Perspective from the Pacific Northwest of North America. Journal of the North American Benthological Society, Vol. 24:3, pp. 724-737

$\checkmark$ Cale, William G.; Henebry, Geoffrey M.; Yeakley, J. Alan. 1989. Inferring Process from Pattern in Natural Communities. BioScience, Vol. 39:9, pp. 600605 
$\checkmark$ Carey, Cynthia; Heyer, W. Ronald; Wilkinson, John; Alford, Ross A.; Arntzen, J. W.; Halliday, Tim; Hungerford, Laura; Lips, Karen R.; Middleton, Elizabeth M.; Orchard, Stan A.; Rand, A. Stanley. 2001. Amphibian Declines and Environmental Change: Use of Remote-Sensing Data to Identify Environmental Correlates. Conservation Biology Vol. 15:4, pp. 903-913

$\checkmark$ City of Portland, CH2MHill. 2004. Innovative Wet Weather Program. Environmental Assessment: U.S. Environmental Protection Agency, April 2004.

$\checkmark$ City of Portland, Oregon. 2012. Wildversation: BioBlitz for Forest Park Wildlife 2012: Data Summary. http://www.portlandonline.com/parks/index.cfm?c=57579. Accessed July $5^{\text {th }}$, 2012.

$\checkmark$ City of Vancouver. 2007. Shoreline Management Master Program. http://www.cityofvancouver.us/upload/images/Planning/CAO/Vancouver_W A_SMP_Effective_April_9_2007\%20.pdf. Accessed July 15 ${ }^{\text {th }}, 2012$.

$\checkmark$ Corkran, Charlotte C. 2005. Errol Heights Amphibian Habitat Study. Report: Prepared for the City of Portland Bureau of Environmental Services.

$\checkmark$ Corn, Paul Stephen; Bury, Bruce. 1989. Logging in Western Oregon: Responses of Headwater Habitats and Stream Amphibians. Forest Ecology and Management, Vol. 29, pp. 39-57

$\checkmark$ Cummins, Kenneth W. 1962. An Evaluation of some Techniques for the Collection and Analysis of Benthic Samples with Special Emphasis on Lotic Waters. American Midland Naturalist, Vol. 67:2, pp. 477-504

$\checkmark$ Crawford, John A.; Semlitsch, Raymond D. 2008. Abiotic Factors Influencing Abundance and Microhabitat Use of Stream Salamanders in Southern Appalachian Forests. Forest Ecology and Management Vol. 255, pp. 18411847

$\checkmark$ Crump, Martha L. 2005. Why Are Some Species in Decline but Others Not? In: Amphibian Declines: The Conservation Status of United States Species. Lannoo, Michael (Ed.). University of California Press, Berkeley, CA. pp. 7-9

$\checkmark$ Cushman, Samuel A. 2006. Effects of Habitat Loss and Fragmentation on Amphibians: A Review and Prospectus. Biological Conservation, Vol. 128, pp. 231-240 
$\checkmark$ Davic, Robert D.; Orr, Lowell P. 1987. The Relationship between Rock Density and Salamander Density in a Mountain Stream. Herpetologica, Vol. 43:3, pp. 357-361

$\checkmark$ Davidson, Carlos; Shaffer, H. Bradley; Jennings, Mark R. 2001. Declines of the California Red-Legged Frog: Climate, UV-B, Habitat, and Pesticides Hypothesis. Ecological Applications Vol. 11:2, pp. 464-479

$\checkmark$ Entrix, Inc. 2010. WHI Environmental Foundation Study. City of Portland Bureau of Planning and Sustainability. July, 2010.

$\checkmark$ Fausch, Kurt D.; Torgersen, Christian E.; Baxter, Colden V.; Li, Hiram W. 2002. Landscapes to Riverscapes: Bridging the Gap between Research and Conservation of Stream Fishes. BioScience Vol. 52:6, pp. 483-498

Fitzhugh, Thomas W.; Richter, Brian D. 2004. Quenching Urban Thirst: Growing Cities and Their Impacts on Freshwater Ecosystems. BioScience, Vol. 54:8, pp. 741-754

$\checkmark$ Green, David M. 2005. Biology of Amphibian Declines. In: Amphibian Declines: The Conservation Status of United States Species. Lannoo, Michael (Ed.). University of California Press, Berkeley, CA. pp. 28-33

$\checkmark$ Grant, Evan H. Campbell; Green, Linda E.; Lowe, Winsor H. 2009. Salamander Occupancy in Headwater Stream Networks. Freshwater Biology, Vol. 54, pp. 1370-1378

$\checkmark$ Halliday, Tim. 2005. Diverse Phenomena Influencing Amphibian Population Declines. In: Amphibian Declines: The Conservation Status of United States Species. Lannoo, Michael (Ed.). University of California Press, Berkeley, CA. pp. 3-6

$\checkmark$ Hennings, Lori A.; Edge, W. Daniel. 2003. Riparian Bird Community Structure in Portland, Oregon: Habitat, Urbanization and Spatial Scale Patterns. The Condor Vol. 105, pp. 288-302

$\checkmark$ Highton, Richard. 2005. Declines of Eastern North American Woodland Salamanders (Plethadon). In: Amphibian Declines: The Conservation Status of United States Species. Lannoo, Michael (Ed.). University of California Press, Berkeley, CA. pp. 34-46

$\checkmark$ Holzer, Katie. 2009(a). Two-year Study of Amphibians in Oaks Bottom Wildlife Refuge. Report: City of Portland Bureau of Parks and Recreation. 
$\checkmark$ Holzer, Katie. 2009(b). Amphibians in the City: Presence, Influential Factors, and Recommendations in Portland, OR. Report: City of Portland Bureau of Parks and Recreation, Bureau of Environmental Services, August 2009.

$\checkmark$ Horne, M. T.; Dunson, W. A. 1994. The Interactive Effects of Low pH, Toxic Metals, and DOC on a Simulated Temporary Pond Community. Environmental Pollution, Vol. 89:2, pp. 155-161

$\checkmark$ Houck, Michael C.; Cody, M. J. (Eds.) 2011. Wild in the City: Exploring the Intertwine Second Edition. Oregon State University Press, Corvallis OR

$\checkmark$ Jewett Jr., Stanley G. 1936. Notes on the Amphibians of the Portland, Oregon, Area. Copeia Vol. 1936:1, pp. 71-72

$\checkmark$ Jones, Lawrence L. C.; Leonard, William P.; Olson, Deanna H. (Eds.). 2005. Amphibians of the Pacific Northwest. Seattle Audubon Society, Seattle WA.

$\checkmark$ Kluber, Matthew R.; Olson, Deanna H.; Puettman, Klaus J. 2008. Amphibian Distribution in Riparian and Upslope Areas and Their Habitat Associations on Managed Forest Landscapes in the Oregon Coast Range. Forest Ecology and Management Vol. 256, pp. 529-535

$\checkmark$ Knopf, Fritz L.; Johnson, R. Roy; Rich, Terrell; Samson, Fred B.; Szaro, Robert C. 1988. Conservation of Riparian Ecosystems in the United States. The Wilson Bulletin Vol. 100:2, pp. 272-284

$\checkmark$ Knutson, Melinda G., Sauer, John R., Olsen, Douglas A., Mossman, Michael J., Hemesath, Lisa M., Lannoo, Michael J. 1999. Effects of Landscape Composition and Wetland Fragmentation on Frog and Toad Abundance and Species Richness in Iowa and Wisconsin, U.S.A. Conservation Biology, Vol. 13:6, pp. 1437-1446

$\checkmark$ Kroll, Andrew J.; Risenhoover, Ken; McBride, Tim; Beach, Eric; Kernohan, Brian J.; Light, Jeff; Bach, Janette. 2008. Factors Influencing Stream Occupancy and Detection Probability Parameters of Stream-Associated Amphibians in Commercial Forests of Oregon and Washington, USA. Forest Ecology and Management, Vol. 255, pp. 3726-3735

$\checkmark$ Lannoo, Michael (Ed.). 2005. Amphibian Declines: The Conservation Status of United States Species. University of California Press, Berkeley CA

Lehtinen, Richard M., Galatowitsch, Susan M., Tester, John R. 1999. Consequences of Habitat Loss and Fragmentation for Wetland Amphibian Assemblages. Wetlands, Vol. 19:1, pp. 1-12 
Lev, E.; Sharp, L. 1991. The Portland-Vancouver Natural Areas Inventory: Field Surveys and Preliminary Wildlife Data. In: Wildlife Conservation in Metropolitan Environments. L. W. Adams and D.L. Leedy (Eds.). National Institute for Urban Wildlife Symposium Series 2. National Institute for Urban Wildlife, Columbia MD, pp. 236-241

$\checkmark$ Lovett-Doust, Jon, Kuntz, Kathryn. 2001. Land Ownership and Other Landscape-Level Effects on Biodiversity in Southern Ontario's Niagra Escarpment Biosphere Reserve, Canada. Landscape Ecology, Vol. 16, pp. 743-755

$\checkmark$ MacKenzie, Darryl I.; Nichols, James D.; Royle, J. Andrew; Pollock, Kenneth H.; Bailey, Larissa L.; Hines, James E. 2006. Occupancy Estimation and Modeling: Inferring Patterns and Dyamics of Species Occurrence. Academic Press, Burlington, MA

$\checkmark$ Marsh, David M.; Trenham, Peter C. 2001. Metapopulation Dynamics and Amphibian Conservation. Conservation Biology, Vol. 15:1, pp. 40-49

$\checkmark$ Metro. 2000. The Nature of 2040: The Region's 50-year Plan for Managing Growth. Available at: http://library.oregonmetro.gov/files/natureof2040.pdf. Accessed July 15th, 2012.

$\checkmark$ Miller, Jennifer E.; Hess, George R.; Moorman, Christopher E. 2007. Southern Two-Lined Salamanders in Urbanizing Watersheds. Urban Ecosystems Vol. 10, pp. 73-85

$\checkmark$ Moore, Aaron A.; Palmer, Margaret A. 2005. Invertebrate Biodiversity in Agricultural and Urban Headwater Streams: Implications for Conservation and Management. Ecological Applications, Vol. 15:4, pp. 1169-1177

$\checkmark$ Naiman, Robert J.; Bilby, Robert E.; Bisson, Peter A. 2000. Riparian Ecology and Management in the Pacific Coastal Rain Forest. BioScience, Vol. 50:11, pp. 996-1011

$\checkmark$ Olson, Deanna H.; Anderson, Paul D.; Frissell, Christopher L.; Welsh Jr., Hartwell H.; Bradford, David F. 2007. Biodiversity Management Approaches for Stream-Riparian Areas: Perspectives from Pacific Northwest headwater forests, microclimates, and amphibians.

$\checkmark$ Orser, Paul N.; Shure, Donald J. 1972. Effects of Urbanization on the Salamander Desmognathus Fuscus Fuscus. Ecology Vol. 53:6, pp. 1148-1154 
$\checkmark$ Ozawa, Connie P.; Yeakley, J. Alan. 2007. Performance of Management Strategies in the Protection of Riparian Vegetation in Three Oregon Cities. Journal of Environmental Planning Vol. 50:6, pp. 803-822

$\checkmark$ Parker, Michael S. 1991. Relationship between Cover Availability and Larval Pacific Giant Salamander Density. Journal of Herpetology, Vol. 25:3, pp. $355-357$

$\checkmark$ Paul, Michael J.; Meyer, Judy L. 2001. Streams in the Urban Lanscape. Annual Review of Ecology and Systematics, Vol. 32, pp. 333-365

$\checkmark$ Pearson, Scott F.; Manuwal, David A. 2001. Breeding Bird Response to Riparian Buffer Width in Managed Pacific Northwest Douglas-Fir Forests. Ecological Applications, Vol. 11:3, pp. 840-853

$\checkmark$ Perkins, D. W.; Hunter Jr., M. L. 2006. Use of Amphibians to Define Riparian Zones of Headwater Streams. Canadian Journal of Forest Restoration, Vol. 36, pp. 2124-2130

$\checkmark$ Poracsky, J. 1991. The Portland-Vancouver Natural Areas Inventory: Photo Interpretation and Mapping. In: Wildlife Conservation in Metropolitan Environments. L. W. Adams and D.L. Leedy (Eds.). National Institute for Urban Wildlife Symposium Series 2. National Institute for Urban Wildlife, Columbia MD, pp. 231-235

$\checkmark$ Price, Steven J.; Cecala, Kristen K.; Browne, Robert A.; Dorcas, Michael E. 2010. Effects of Urbanization on Occupancy of Stream Salamanders. Conservation Biology, Vol. 25, pp. 547-555

$\checkmark$ Price, Steven J.; Browne, Robert A.; Dorcas, Michael E. 2011. Evaluating the Effects of Urbanisation on Salamander Abundances Using a Before-After Control-Impact Design. Freshwater Biology, Vol. 57:1, pp. 193-203

$\checkmark$ Pusey, Bradley J.; Arthington, Angela H. 2003. Importance of the Riparian Zone to the Conservation and Management of Freshwater Fish: A Review. Marine and Freshwater Research, Vol. 54, pp. 1-16

$\checkmark$ Riley, Seth P.D.; Busteed, Gary T.; Kats, Lee B.; Vandergon, Thomas L.; Lee, Lena F. S.; Dagit, Rosi G.; Kerby, Jacob L.; Fisher, Robert N.; Sauvajot, Raymond M. 2005. Effects of Urbanization on the Distribution and Abundance of Amphibians and Invasive Species in Southern California Streams. Conservation Biology, Vol. 19:6, pp. 1894-1907 
$\checkmark$ Roberts, Laura. 2005. Woodland Amphibian Distribution in Parks and Greenspaces of the Portland Oregon Metropolitan Area: A Multiple Scale Investigation. Master's Thesis, Biology Department, Portland State University.

$\checkmark$ Semlitsch, Raymond D.; Bodie, J. Russell. 2003. Biological Criteria for Buffer Zones around Wetlands and Riparian Habitats for Amphibians and Reptiles. Conservation Biology, Vol. 17:5, pp. 1219-1228

$\checkmark$ Stoddard, Margo A.; Hayes, John P. 2005. The Influence of Forest Management on Headwater Stream Amphibians at Multiple Spatial Scales. Ecological Applications, Vol. 15:3, pp. 811-823

$\checkmark$ Swanson, F. J.; Franklin, J. F. 1992. New Forestry Principles from Ecosystem Analysis of Pacific Northwest Forests. Ecological Applications, Vol. 2:3, pp. 262-274

$\checkmark$ The Intertwine Alliance. 2012. Acquisition: Building the Intertwine, One Piece at a Time. http://www.theintertwine.org/acquisition. Updated: 2012. Accessed: June 27, 2012

$\checkmark$ United Nations. 2008. World urbanization prospectis: the 2007 revision. United Nations, New York, New York, USA.

$\checkmark$ Vesely, David G.; McComb, William C. 2002. Salamander Abundance and Amphibian Species Richness in Riparian Buffer Strips in the Oregon Coast Range. Forest Science, Vol. 48:2, pp. 291-297

$\checkmark$ Welsh Jr., Hartwell H.; Ollivier, Lisa M. 1998. Stream Amphibians as Indicators of Ecosystem Stress: A Case Study from California's Redwoods. Ecological Applications Vol. 8:4, pp. 1118-1132

$\checkmark$ Welsh Jr., Hartwell H.; Lind, Amy J. 2002. Multiscale Habitat Relationships of Stream Amphibians in the Klamath-Siskyou Region of California and Oregon. The Journal of Wildlife Management Vol. 66:3, pp. 581-602

Whiles, Matt R.; Lips, Karen R.; Pringle, Cathy M.; Kilham, Susan S.; Bixby, Rebecca J.; Brenes, Roberto; Connelly, Scott; Colon-Gaud, Jose Checo; Hunte-Brown, Meshagae; Huryn, Alexander D.; Montgomery, Chad; Peterson, Scot. 2006. The Effects of Amphibian Population Declines on the Structure and Function of Neotropical Stream Ecosystems. Frontiers in Ecology and the Environment, Vol. 4:1, pp. 27-34 
$\checkmark$ Wilkins, R. Neal, Peterson, N. Phil. 2000. Factors Related to Amphibian Occurrence and Abundance in Headwater Streams Draining Second-Growth Douglas-Fir Forests in Southwestern Washington. Forest Ecology and Management, Vol. 139, pp. 79-91

$\checkmark$ Willson, John D; Dorcas, Michael E. 2003. Effects of Habitat Disturbance on Stream Salamanders: Implications for Buffer Zones and Watershed Management. Conservation Biology, Vol. 17:3, pp. 763-771

$\checkmark$ Wissmar, Robert C.; Beschta, Robert L. 1998. Restoration and Management of Riparian Ecosystems: A Catchment Perspective. Freshwater Biology, Vol. 40, pp. 571-585

$\checkmark$ Wu, JunJie; Adams, Richard M.; Boggess, William G. 2000. Cumulative Effects and Optimal Targeting of Conservation Efforts: Steelhead Trout Habitat Enhancement in Oregon. American Journal of Agricultural Economics Vol. 82:2, pp. 400-413

$\checkmark$ Youngman, Jessica Lynn. 2002. Biogeographic and Land Cover Effects on Urban Riparian Plant Assemblages. Master's Thesis, Portland State University 


\section{Appendices}

\section{Appendix A - Potential Environmental Parameters Affecting Stream Amphibians}

Appendix A - This is a comprehensive list of environmental variables at various spatial scales which might correlate with stream amphibian communities. Underlined selections were determined feasible for measuring during the spring/summer 2011 field season based on time and financial limitations. Sources utilized during compilation of this list include: Welsh and Lind, 2002, Grant et al., 2009, Snodgrass et al., 2007, Kluber et al., 2008, Orser and Shure, 1972, Riley et al., 2005, Wilkins and Peterson, 2000, Youngman, 2002, and Sharp, 2002.

\begin{tabular}{|c|c|}
\hline \multicolumn{2}{|c|}{$\underline{\text { Amphibian response variables }}$} \\
\hline$\%$ & Diversity (Shannon's Index) \\
\hline 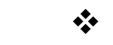 & Species Richness \\
\hline 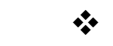 & $\overline{\text { Abundance }}$ \\
\hline 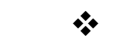 & 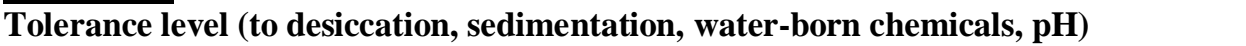 \\
\hline$*$ & Primary Habitat Utilized (Aquatic vs. terrestrial) \\
\hline$*$ & Exclusion via other amphibians \\
\hline \multicolumn{2}{|c|}{ Biogeographic variables } \\
\hline$>$ & Elevation of stream, channel gradient (slope), channel aspect \\
\hline$>$ & Upstream development (related to sediment inputs) \\
\hline$>$ & $\begin{array}{l}\text { Impervious surfaces, surrounding land uses (urban, industrial, suburban, } \\
\text { agriculture) w/in catchment }\end{array}$ \\
\hline$>$ & Connectivity of forest habitat \\
\hline$>$ & Land-use history (e.g. time since last logging/large-scale disturbance) \\
\hline$>$ & Site latitude, solar index \\
\hline$>$ & Distance to nearest path/road/house/railroad/bridge and frequency of use for \\
\hline & $\overline{\text { identified feature }}$ \\
\hline$>$ & Surrounding land ownership (public (which agency?)/private) \\
\hline \multicolumn{2}{|c|}{ Stream reach variables } \\
\hline$\checkmark$ & Soils/edaphic variables \\
\hline$\checkmark$ & $\begin{array}{l}\text { Water quality (in stream, measured at least in the late spring and late summer, such } \\
\text { as pH, temp, conductivity, dissolved } O \text {, nutrient loading, biocides, heavy metals) }\end{array}$ \\
\hline$\checkmark$ & Canopy density/UV exposure \\
\hline$\checkmark$ & Stream size (discharge), Rain flow volume/time since last precipitation event \\
\hline$\checkmark$ & Mesohabitat \%'s (riffle v. pool v. run) \\
\hline$\checkmark$ & $\overline{\text { Air moisture (humidity) }}$ \\
\hline$\checkmark$ & Forest structure (age, dominant canopy tree, dominant understory vegetation, \\
\hline & dominant ground cover, \% cover at each level) \\
\hline$\checkmark$ & Active Management of Riparian Vegetation \\
\hline$\checkmark$ & Invertebrate community diversity/abundance (prey base) \\
\hline$\checkmark$ & Distance to nearest pipe/interruption of stream-flow \\
\hline \multicolumn{2}{|c|}{ Microhabitat variables } \\
\hline & Mesohabitat (of sampled sections) \\
\hline & Seeps feeding into sites \\
\hline$\bullet$ & $\begin{array}{l}\text { Amount and type of cover (woody, leaf-pack, rocky substrate (size classes)), both } \\
\text { aquatic and terrestrial }\end{array}$ \\
\hline & Presence of predators/competitors (other amphibians/fish/crayfish) \\
\hline & Aquatic conditions (water temp, velocity, depth, width, bank slope) \\
\hline$\bullet$ & Canopy closure \\
\hline$\bullet$ & Weather (during sampling session) \\
\hline$\bullet$ & Air temperature \\
\hline$\bullet$ & icators of human activity along stream stretch \\
\hline
\end{tabular}




\section{Appendix B - Amphibians Endemic to the Portland-Vancouver Region}

Appendix B - This chart is a comprehensive list of all amphibian species with known ranges in the General Portland, OR region and Clark County, WA. It is divided into Stream-Obligate species, which are known to breed in streams, and Stream-Facultative species, which breed elsewhere but may utilize streams for habitat and to forage. Sources: Jones et al., 2005; Bartlett and Bartlett, 2009

\begin{tabular}{|c|c|c|c|}
\hline Species & Common Name & $\begin{array}{l}\text { Larval } \\
\text { Habitat }\end{array}$ & Juvenile/Adult Habitat \\
\hline \multicolumn{4}{|c|}{ Stream-Obligate Species } \\
\hline $\begin{array}{l}\text { Dicamptodon } \\
\text { tenebrosus }\end{array}$ & Pacific Giant Salamander & In Stream & $\begin{array}{l}\text { Terrestrial/Some } \\
\text { neoteny }\end{array}$ \\
\hline Dicamptodon copeii & Cope's Giant Salamander & In Stream & $\begin{array}{l}\text { In Stream - Neoteny is } \\
\text { common }\end{array}$ \\
\hline Rhyacotriton cascadae & $\begin{array}{l}\text { Cascade Torrent } \\
\text { Salamander }\end{array}$ & In Stream & Streamside \\
\hline Ascaphus truei & Coastal Tailed Frog & In Stream & Terrestrial/Streamside \\
\hline \multicolumn{4}{|c|}{ Stream-Facultative Species } \\
\hline Ambystoma gracile & Northwestern Salamander & Ponds & Pond-side/Terrestrial \\
\hline $\begin{array}{l}\text { Ambystoma } \\
\text { macrodactylum } \\
\text { macrodactylum }\end{array}$ & $\begin{array}{l}\text { Western Long-Toed } \\
\text { Salamander }\end{array}$ & Ponds & Pond-side/Terrestrial \\
\hline $\begin{array}{l}\text { Taricha granulosa } \\
\text { granulosa }\end{array}$ & Rough-Skinned Newt & $\begin{array}{l}\text { Ponds/Slow } \\
\text { Waters }\end{array}$ & Terrestrial \\
\hline Aneides ferreus & Clouded Salamander & N/A & Terrestrial \\
\hline $\begin{array}{l}\text { Ensatina eschscholtzii } \\
\text { oregonensis }\end{array}$ & Oregon Ensatinas & N/A & Terrestrial \\
\hline Plethodon dunni & Dunn's Salamander & N/A & Terrestrial \\
\hline Plethodon vehiculum & $\begin{array}{l}\text { Western Red-backed } \\
\text { Salamander }\end{array}$ & N/A & Terrestrial \\
\hline Rana pretiosa & Oregon Spotted Frog & Ponds & Pond-side/Terrestrial \\
\hline Rana catesbeiana & Bullfrog & Ponds & Pond-side/Terrestrial \\
\hline Rana aurora & Northern Red-Legged Frog & $\begin{array}{l}\text { Ponds/Slow } \\
\text { Waters }\end{array}$ & Terrestrial \\
\hline Pseudacris regilla & Pacific Treefrog & $\begin{array}{l}\text { Ponds/Slow } \\
\text { waters }\end{array}$ & Terrestrial \\
\hline Bufo boreas & Western Toad & $\begin{array}{l}\text { Ponds/Slow } \\
\text { waters }\end{array}$ & Terrestrial \\
\hline
\end{tabular}




\section{Appendix C - Mailing Postcard Example}
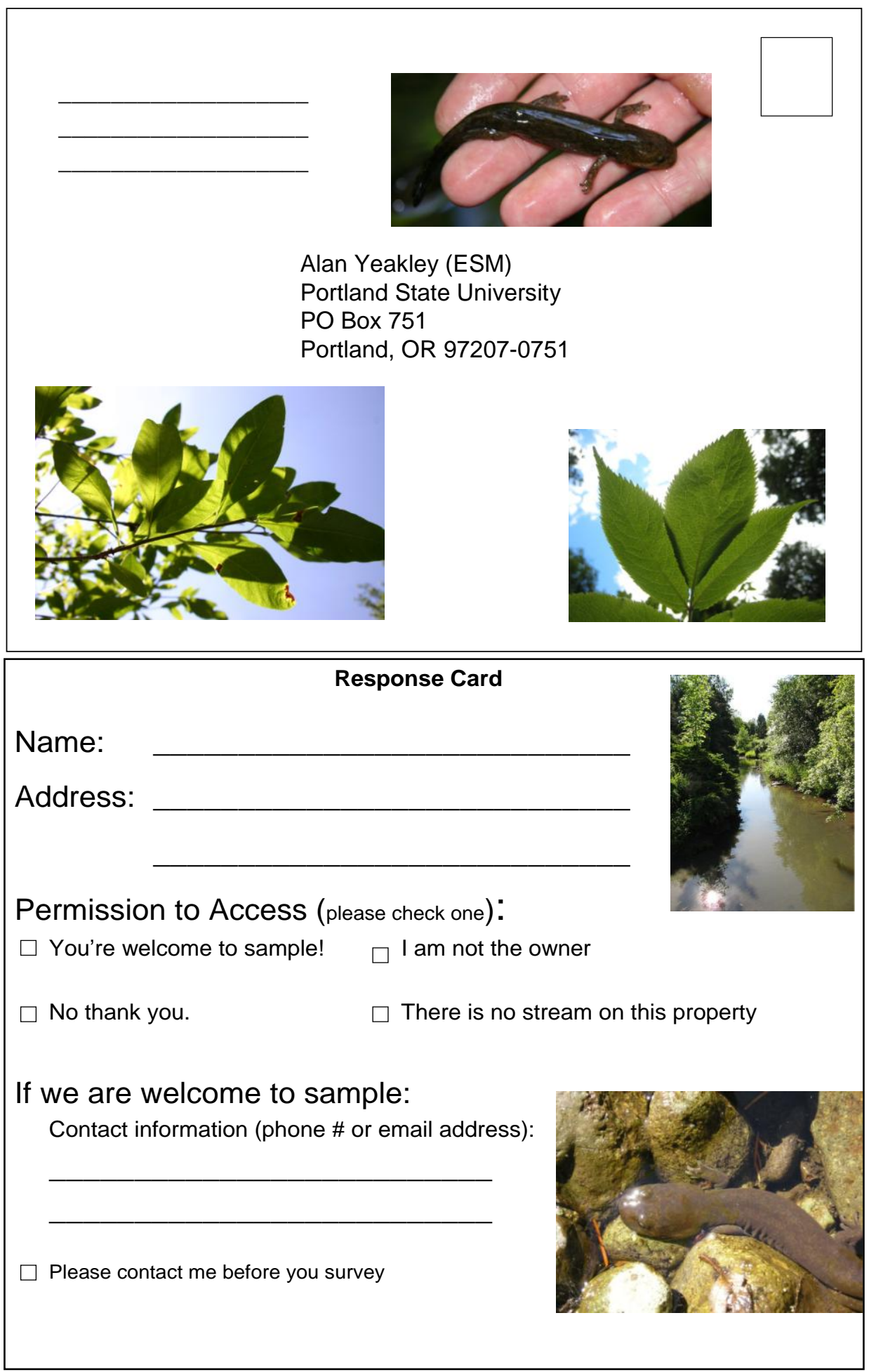

Appendix C - Displayed above is the postcard that was sent to private land owners during the site selection process in an attempt to gain access into people's properties. 


\section{Appendix D - Transect Location Adjustment Justifications}

Appendix D - Below is a list of the sites where the location of a stream transect was altered from that selected randomly by remote sensing.

\begin{tabular}{|l|l|l|}
\hline $\begin{array}{c}\text { Site } \\
\text { Code }\end{array}$ & \multicolumn{1}{|c|}{ Stream Name } & \multicolumn{1}{c|}{ Reason for Adjustment of Site Location } \\
\hline A20 & N/A & $\begin{array}{l}\text { Wetted length of selected stream segment too short and too close to } \\
\text { culverts bracketing the ends of segment. Adjacent stream segment } \\
\text { sampled above confluence point. }\end{array}$ \\
\hline C2 & Boulder Creek & $\begin{array}{l}\text { Site was located in dense, steep forest making hiking difficult and } \\
\text { actual location (a tributary further north) inaccessible. Tributary south } \\
\text { of selected stream segment sampled. }\end{array}$ \\
\hline
\end{tabular}




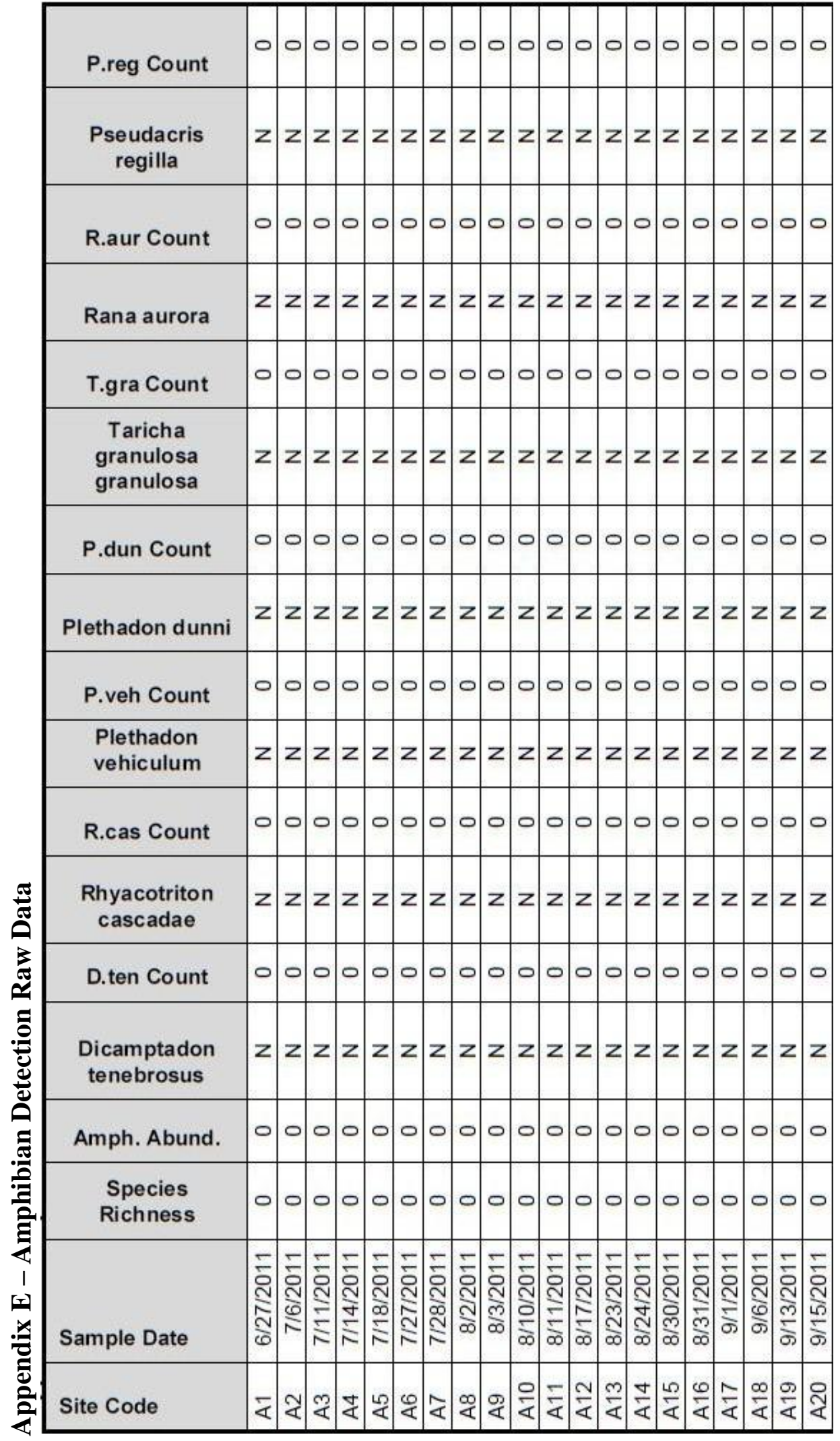




\begin{tabular}{|c|c|c|c|c|c|c|c|c|c|c|c|c|c|c|c|c|c|}
\hline P.reg Count & 0 & 0 & 0 & 이 & o & - & 0 & 0 & 0 & 0 & 0 & 이 & 0 & o & 0 & & $\circ$ \\
\hline $\begin{array}{l}\text { Pseudacris } \\
\text { regilla }\end{array}$ & $z$ & $z$ & $z$ & $z$ & $z$ & $>$ & $z$ & $z$ & $z$ & $z$ & $z$ & $z$ & $z$ & $z$ & $z$ & & $z$ \\
\hline R.aur Count & 0 & 0 & 0 & o & $\nabla$ & - & 0 & o & 0 & 0 & 0 & 이 & 0 & o) & 0 & & 0 \\
\hline Rana aurora & $z$ & $z$ & $z$ & $z$ & $>$ & $>$ & $z$ & $z$ & $z$ & $z$ & $z$ & $z$ & $z$ & $z$ & $z$ & & $z$ \\
\hline T.gra Count & o & 0 & 0 & o & o & 이 & 0 & o & 0 & 0 & 0 & $N$ & 0 & 이 & 이 & o & - \\
\hline $\begin{array}{l}\text { Taricha } \\
\text { granulosa } \\
\text { granulosa }\end{array}$ & $z$ & $z$ & $z$ & $z$ & $z$ & $z$ & $z$ & $z$ & $z$ & $z$ & $z$ & $>$ & $z$ & $z$ & $z$ & $z$ & $>$ \\
\hline P.dun Count & 0 & 0 & 0 & $\nabla$ & o & 이 & 0 & o & w & 0 & 0 & o & 0 & 0 & + & & 0 \\
\hline Plethadon dunni & $z$ & $z$ & $z$ & $>$ & $z$ & $z$ & $z$ & $z$ & $>$ & $z$ & $z$ & $z$ & $z$ & $z$ & $>$ & & $z$ \\
\hline P.veh Count & - & 10 & - & o & o & 이 & 0 & 0 & N & a & $\nabla$ & - & $\Lambda$ & + & 2) & 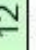 & 0 \\
\hline $\begin{array}{l}\text { Plethadon } \\
\text { vehiculum }\end{array}$ & $>$ & $>$ & $>$ & $z$ & $z$ & $z$ & $z$ & $z$ & $>$ & $>$ & $>$ & $>$ & $>$ & $>$ & $\succ$ & & $z$ \\
\hline R.cas Count & o & 0 & 0 & o & o & 이 & N & o & 0 & 0 & 0 & 이 & 0 & o & 0 & & 0 \\
\hline $\begin{array}{l}\text { Rhyacotriton } \\
\text { cascadae }\end{array}$ & $z$ & $z$ & $z$ & $z$ & $z$ & $z$ & $>$ & $z$ & $z$ & $z$ & $z$ & $z$ & $z$ & $z$ & $z$ & & $z$ \\
\hline D.ten Count & 0 & 0 & 0 & 0 & o & 이 & 0 & $\sigma$ & ৪ & - & - & $N$ & - & 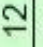 & $\mp$ & $\stackrel{\mathrm{N}}{\simeq}$ & A \\
\hline $\begin{array}{l}\text { Dicamptadon } \\
\text { tenebrosus }\end{array}$ & $z$ & $z$ & $z$ & $z$ & $z$ & $z$ & $z$ & $>$ & $>$ & $>$ & $>$ & $>$ & $>$ & $>$ & $>$ & & $>$ \\
\hline Amph. Abund. & - & 10 & - & $\nabla$ & $\nabla$ & $\sim$ & 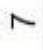 & o & ৪) & 은 & 100 & is & $\infty$ & $\stackrel{2}{2}+1-1+1$ & ले & & مـا \\
\hline $\begin{array}{l}\text { Species } \\
\text { Richness }\end{array}$ & - & - & - & - & - & $N$ & - & - & $m$ & N & $N$ & m & N & & m & & 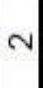 \\
\hline Sample Date & $\begin{array}{l}\frac{1}{\delta} \\
\text { N } \\
\omega \\
\end{array}$ & $\begin{array}{l}\bar{\Sigma} \\
\text { N } \\
\text { N } \\
\stackrel{N}{N}\end{array}$ & $\mid \begin{array}{l}\overline{-} \\
\text { న్ } \\
\text { } \\
\infty\end{array}$ & $\begin{array}{l}\frac{\nwarrow}{5} \\
\text { స్ } \\
\frac{1}{\infty}\end{array}$ & $\begin{array}{l}\frac{\Xi}{0} \\
\frac{N}{0} \\
\frac{\infty}{\infty}\end{array}$ & 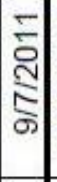 & $\frac{\bar{\sigma}}{\frac{\Gamma}{\delta}}$ & $\begin{array}{l}\bar{\delta} \\
\text { స̦ } \\
\text { స్ } \\
\delta\end{array}$ & $\underset{\substack{\frac{E}{S} \\
\frac{N}{6}}}{\frac{1}{6}}$ & 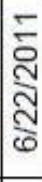 & 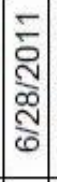 & $\begin{array}{l}\frac{1}{0} \\
\text { స్ } \\
\stackrel{N}{N}\end{array}$ & 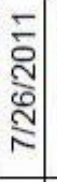 & $\frac{\check{N}}{\infty}$ & 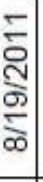 & 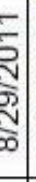 & $\begin{array}{l}\frac{5}{5} \\
\frac{N}{2} \\
\frac{1}{2}\end{array}$ \\
\hline ite Code & $\infty$ & 10 & 网 & 㐫 & ๓ి & $\mid$ & $\bar{u}$ & & 0 & i & $\mid 03$ & 8 & $\hat{U}$ & 必 & ভ্ & $\bar{u}$ & 5 \\
\hline
\end{tabular}




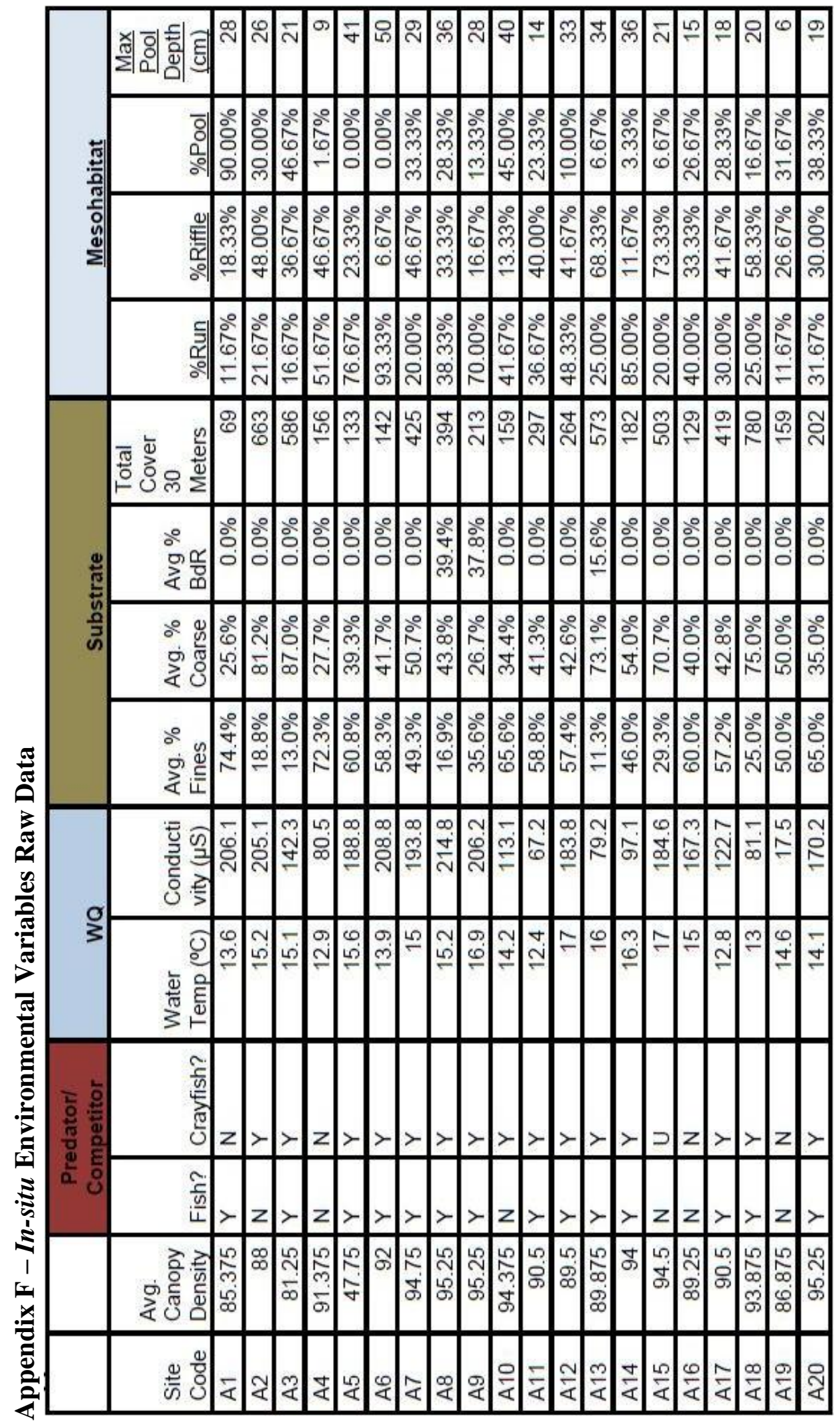




\begin{tabular}{|c|c|c|c|c|c|c|c|c|c|c|c|c|c|c|c|c|c|c|}
\hline \multirow{4}{*}{ 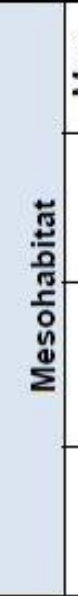 } & 䒽 & & & & $\overline{\mathrm{N}}$ & & Z & लొ & & $\begin{array}{l}\text { \& } \\
\text { Ni }\end{array}$ & & $\omega$ & సొ & $\stackrel{\sim}{\sim}$ & $\stackrel{\infty}{-}$ & $\approx$ & \pm & $\ddot{~ m}$ \\
\hline & 힝 & लें & 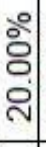 & $\begin{array}{l}\text { ठे. } \\
\text { సें }\end{array}$ & 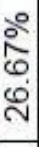 & 今े & $\begin{array}{l}\text { ठें } \\
\text { ठे. } \\
\text { ले }\end{array}$ & $\begin{array}{l}\text { लें } \\
\text { సें }\end{array}$ & 今े & $\begin{array}{l}\text { 今े } \\
\text { ठ․ } \\
\text { ले }\end{array}$ & $\begin{array}{l}\text { लें } \\
\text { ले } \\
\text { iे }\end{array}$ & 今े & $\begin{array}{l}\stackrel{2}{0} \\
\frac{\hat{\sigma}}{N}\end{array}$ & : & ڤั) & 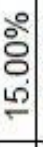 & $\begin{array}{l}\text { ले } \\
\text { mे } \\
\infty\end{array}$ & ले \\
\hline & $\begin{array}{l}\frac{0}{\underline{T}} \\
\frac{0}{0} \\
\text { 예 }\end{array}$ & $\begin{array}{l}\text { ले } \\
\text { ले }\end{array}$ & 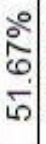 & $\begin{array}{l}\text { लें } \\
\text { ले } \\
\text { సे }\end{array}$ & $\begin{array}{l}\text { ले } \\
\text { ले } \\
\infty \\
\infty\end{array}$ & लें & $\begin{array}{l}\stackrel{0}{0} \\
0 \\
0 \\
0\end{array}$ & लें & 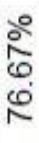 & 今े & लें & 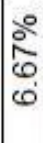 & $\begin{array}{l}\stackrel{8}{0} \\
6 \\
\stackrel{8}{0}\end{array}$ & $\mid$ & लें & 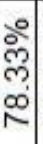 & 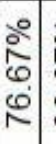 & $\begin{array}{l}\circ \\
0 \\
0 \\
0\end{array}$ \\
\hline & 돔 & लें & $\begin{array}{l}\text { ळे } \\
\text { ले } \\
\text { సे }\end{array}$ & 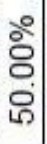 & 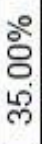 & $\mid \begin{array}{c}0 \\
\vdots \\
0 \\
\frac{\dot{\sigma}}{}\end{array}$ & $\begin{array}{l}\text { ले } \\
\text { ले } \\
\infty \\
\infty\end{array}$ & $\begin{array}{l}\text { लें } \\
\text { ले } \\
\stackrel{2}{-}\end{array}$ & $\begin{array}{l}\text { 8े } \\
\text { : }\end{array}$ & 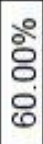 & 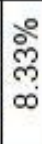 & ले & 童 & 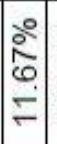 & 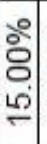 & $\begin{array}{l}\stackrel{0}{0} \\
6 \\
6\end{array}$ & 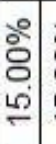 & $\begin{array}{l}\text { ஃ̊ } \\
8 \\
\text { ஸे }\end{array}$ \\
\hline & 퐁 & $\hat{y}$ & 足 & $\widehat{\mathscr{\vartheta}}$ & $\stackrel{\varphi}{\square}$ & থె & 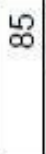 & চ & 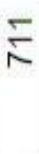 & $\frac{\varphi}{f}$ & న্লে & $\bar{\infty}$ & 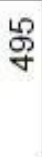 & $\widehat{\widehat{్ ర ె}}$ & : & مొ & 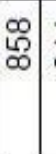 & $\frac{\bar{\infty}}{\infty}$ \\
\hline & 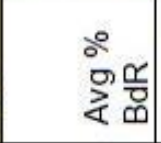 & ○े & $\frac{\circ}{\grave{6}}$ & $\begin{array}{l}\stackrel{2}{2} \\
\underline{6}\end{array}$ & ஃ̊ㅇ & ○ें & $\begin{array}{l}\text { ठें } \\
\text { ○े }\end{array}$ & ఫें & ஃ̊ & $\begin{array}{l}\text { ळे } \\
\infty\end{array}$ & ○े & $\stackrel{\circ}{\frac{2}{-}}$ & ठ̊̊. & ठ̊ㅇ & ठें & ठें & ठ̊. & 웅 \\
\hline$\vec{\omega}$ & 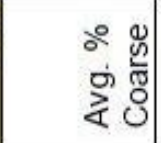 & ळे & $\begin{array}{l}\stackrel{2}{\grave{m}} \\
\dot{m}\end{array}$ & 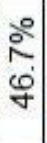 & 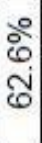 & कें & $\begin{array}{l}\text { ठे } \\
\text { ஸे }\end{array}$ & ণे & $\begin{array}{l}\text { ळे } \\
\text { ஸ் }\end{array}$ & 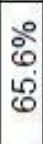 & 今̀ & ले & $\begin{array}{l}\overbrace{}^{\circ} \\
\hat{c}^{\circ}\end{array}$ & $\mid$ & ஓें & ஸें & $\begin{array}{l}0 \\
\vdots \\
0 \\
0\end{array}$ & $\begin{array}{l}\text { ळे } \\
\text { ஸ் }\end{array}$ \\
\hline & $\begin{array}{l}\circ \\
\circ \\
\dot{\infty}\end{array}$ & 今े & సิ & $\begin{array}{l}\stackrel{0}{\circ} \\
\dot{c}\end{array}$ & $\begin{array}{l}\text { ๙े } \\
\text { 仓े }\end{array}$ & $\mid \begin{array}{l}\circ \\
\infty \\
\text { యे }\end{array}$ & $\frac{\circ}{\stackrel{2}{2}}$ & $\begin{array}{l}\text { \&े} \\
\vdots \\
\text { oे }\end{array}$ & ले & $\begin{array}{l}\text { 今े } \\
\text { ఏें }\end{array}$ & $\begin{array}{l}\text { ळे } \\
\text { సิ }\end{array}$ & 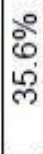 & $\begin{array}{l}\text { ले } \\
\text { พे }\end{array}$ & 号 & $\begin{array}{l}\text { के } \\
\text { के } \\
\text { ले }\end{array}$ & 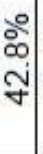 & \begin{tabular}{l} 
oे \\
\multirow{+}{*}{}
\end{tabular} & ๙ิ่ \\
\hline $\begin{array}{l}0 \\
3\end{array}$ & 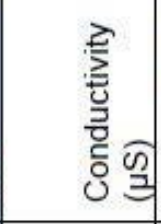 & 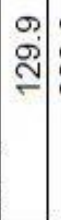 & 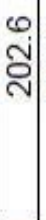 & 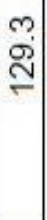 & $\begin{array}{l}-1 \\
0 \\
0 \\
-\end{array}$ & సั่ & $\overline{\check{\S}}$ & ?̊. & N & के & ले & ' & $\begin{array}{l}\mathscr{0} \\
\stackrel{0}{0} \\
\stackrel{0}{0}\end{array}$ & \begin{tabular}{|l|}
$\infty$ \\
0 \\
0 \\
\end{tabular} & $\begin{array}{l}0 \\
0 \\
0 \\
0\end{array}$ & $\frac{N}{0}$ & 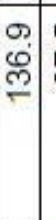 & กิ \\
\hline & 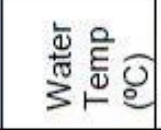 & $\stackrel{0}{=}$ & 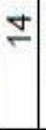 & $\stackrel{\vec{J}}{\square}$ & $\begin{array}{c}m \\
\stackrel{m}{\rightleftharpoons}\end{array}$ & $\begin{array}{l}m \\
m\end{array}$ & $\begin{array}{l}\omega \\
\stackrel{6}{0} \\
\sim\end{array}$ & $\begin{array}{l}\text { बे } \\
\text { ले }\end{array}$ & $\stackrel{m}{=}$ & $\stackrel{+}{\stackrel{\sim}{\sim}}$ & $\stackrel{m}{=}$ & 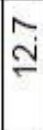 & $\stackrel{m}{\square}$ & $\begin{array}{l}\stackrel{v}{ } \\
\stackrel{m}{\sim}\end{array}$ & के & 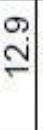 & \begin{tabular}{l}
0 \\
\hdashline \\
$\square$
\end{tabular} & $\stackrel{\sim}{\sim}$ \\
\hline & $\begin{array}{l}\frac{5}{5} \\
\frac{5}{5} \\
\text { 인 }\end{array}$ & $>$ & $>$ & $z$ & $>$ & $>$ & $>$ & $z$ & $>$ & $>$ & $z$ & $z$ & $>$ & $>$ & $>$ & $z$ & $>$ & $>$ \\
\hline & $\frac{\tilde{5}}{\frac{9}{4}}$ & $>$ & $>$ & $z$ & $>$ & $>$ & $>$ & $>$ & $>$ & $z$ & $z$ & $z$ & $z$ & $z$ & $z$ & $z$ & $z$ & $>$ \\
\hline & 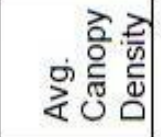 & $\infty$ & $\begin{array}{l}\text { ลี } \\
\text { ผู }\end{array}$ & $\begin{array}{l}\stackrel{2}{2} \\
\delta \\
\delta\end{array}$ & ๘) & $\begin{array}{l}2 \\
\text { के } \\
\text { | }\end{array}$ & $\infty$ & $\begin{array}{l}\llcorner ? \\
\text { मे }\end{array}$ & ஓ & ஜீ & $\stackrel{0}{\varnothing}$ & $\begin{array}{l}\frac{1}{2} \\
\text { ळூ }\end{array}$ & $\begin{array}{l}\text { Nి } \\
\infty \\
\infty\end{array}$ & 吕 & 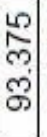 & 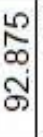 & & த \\
\hline & 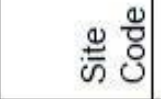 & & & & & & & & & & & 10 & & $\hat{0}$ & & & $\frac{0}{\cup}$ & $\bar{\sigma}$ \\
\hline
\end{tabular}




\section{Appendix G - Additional Vectors included in NMDS Analysis}

Appendix G - This table represents all environmental factors that were not significant at the $p<0.05$ level but were significant at the $\mathrm{p}<0.1$ level.

\begin{tabular}{|l|l|c|c|}
\hline \multicolumn{4}{|c|}{ Other Vectors w/significance (0.1 >p>0.05) } \\
\hline Code & \multicolumn{1}{|c|}{ Names } & $\underline{\text { P-value }}$ \\
\hline X56 & \% Open Water (LC5)(50 meters) & 0.1621 & 0.056943 \\
\hline X143 & \% Sum Paved (LC5)(Sub-watershed) & 0.1556 & 0.054945 \\
\hline X121 & \% Sum Paved (LC5)(300 meters) & 0.1553 & 0.062937 \\
\hline X69 & $\begin{array}{l}\text { \% Coniferous Forest (NLCD)(100 } \\
\text { meters) }\end{array}$ & 0.1551 & 0.050949 \\
\hline X41 & $\begin{array}{l}\text { \% Open Development (NLCD)(50 } \\
\text { meters) }\end{array}$ & 0.1545 & 0.061938 \\
\hline X17 & Adjacent Forest Patch Area & 0.1535 & 0.051948 \\
\hline X126 & \% Agriculture (LC5)(300 meters) & 0.1535 & 0.056943 \\
\hline & $\begin{array}{l}\text { \% Deciduous Forest (NLCD)(300 } \\
\text { meters) }\end{array}$ & 0.1505 & 0.05994 \\
\hline X112 & \% Agriculture (LC5)(200 meters) & 0.15 & 0.067932 \\
\hline X104 & $\begin{array}{l}\text { \% Coniferous Forest (NLCD)(50 } \\
\text { meters) }\end{array}$ & 0.1472 & 0.061938 \\
\hline X40 & \% Agriculture (LC5)(500 meters) & 0.1465 & 0.056943 \\
\hline X82 & \% Agriculture (LC5)(100 meters) & 0.1465 & 0.077922 \\
\hline X65 & $\begin{array}{l}\text { \% Medium Intensity Development } \\
\text { (NLCD)(100 meters) }\end{array}$ & 0.1455 & 0.080919 \\
\hline X51 & \% Pasture/Hay (NLCD)(50 meters) & 0.1436 & 0.074925 \\
\hline X78 & \% Open Water (LC5)(100 meters) & 0.1432 & 0.065934 \\
\hline X100 & \% Open Water (LC5)(200 meters) & 0.1399 & 0.075924 \\
\hline X35 & \% Paved (LC5)(500 meters) & 0.1397 & 0.088911 \\
\hline X73 & \%Pasture/Hay (NLCD)(100 meters) & 0.1369 & 0.072927 \\
\hline X123 & \% Herbaceous (LC5)(300 meters) & 0.1364 & 0.068931 \\
\hline X122 & \% Open Water (LC5)(300 meters) & 0.1352 & 0.080919 \\
\hline X60 & \% Agriculture (LC5)(50 meters) & 0.1349 & 0.095904 \\
\hline X63 & $\begin{array}{l}\text { \% Open Development (NLCD)(100 } \\
\text { meters) }\end{array}$ & 0.1307 & 0.096903 \\
\hline X145 & \% Herbaceous (LC5)(Sub-watershed) & 0.1284 & 0.076923 \\
\hline
\end{tabular}




\section{Appendix H - Logistic Regression Null Hypothesis Testing Results}

Appendix $\mathbf{H}$ - This table represents the results of null-hypothesis testing performed on each of the logistic regression models that contained an environmental variable with significant influence. Each of these models was found to be significantly different from the associated null model, allowing the rejection of the null hypothesis that these models are not different from the null model. $\mathrm{R}^{2}$ values for each model were calculated as well to assess the predictive power of each logistic model and associated environmental variable in relation to amphibian functional group presence.

\begin{tabular}{|c|c|c|c|}
\hline Variable Name & $\begin{array}{c}\text { Null } \\
\text { Hypothesis } \\
\text { Testing: } \\
\text { Deviance } \\
\end{array}$ & $\mathbf{P}(>\mid$ Chi $\mid)$ & $\mathbf{R}^{2}$ \\
\hline \multicolumn{3}{|c|}{ Obligate Presence } & \\
\hline Patchiness & -28.973 & 7.31E-08 & 0.643 \\
\hline \% Herbaceous Vegetation (LC5)(100 meters) & -17.889 & 0.0000234 & 0.397 \\
\hline \% Open Development (NLCD)(50 meters) & -14.703 & 0.000126 & 0.326 \\
\hline \% Sum Paved (LC5)(200 meters) & -21.488 & 0.00000356 & 0.477 \\
\hline Water Temperature & -12.406 & 0.000428 & 0.275 \\
\hline Impervious Surface \% Cover & -13.973 & 0.000186 & 0.310 \\
\hline Water Conductivity & -11.169 & 0.000832 & 0.248 \\
\hline Total Cover & -14.541 & 0.000137 & 0.323 \\
\hline$\%$ Coarse Substrate & -6.5651 & 0.0104 & 0.146 \\
\hline Adjacent Forested Patch Area & -13.362 & 0.000257 & 0.297 \\
\hline$\%$ Hardwoods (LC5)(200 meters) & -8.3022 & 0.0031 & 0.194 \\
\hline \% Riffle & -7.7576 & 0.00535 & 0.172 \\
\hline$\%$ Coniferous Forest (NLCD)(100 meters) & -13.846 & 0.000198 & 0.307 \\
\hline$\%$ Deciduous Forest (NLCD)(Sub-watershed) & -8.7504 & 0.0031 & 0.194 \\
\hline \% Mixed Forest (NLCD)(200 meters) & -35.614 & $2.406 \mathrm{E}-09$ & 0.791 \\
\hline \multicolumn{3}{|c|}{ Facultative Presence } & \\
\hline \% Herbaceous Vegetation (LC5)(100 meters) & -6.652 & 0.009905 & 0.133 \\
\hline \% Open Development (NLCD)(50 meters) & -6.2832 & 0.01219 & 0.126 \\
\hline$\%$ Fine Substrate & -5.1717 & 0.02296 & 0.104 \\
\hline$\%$ Hardwoods (LC5)(200 meters) & -12.547 & 0.0003969 & 0.251 \\
\hline \% Mixed Forest (NLCD)(200 meters) & -17.116 & 0.00003516 & 0.343 \\
\hline
\end{tabular}




\section{Appendix I - Occupancy Model Variable Lists}

Appendix I - This list represents sets of variables found to be significant in relation to the presence of each functional group of amphibians. These variables are chosen from the subsets listed for the $a$ priori models in Table 3. Please refer to Tables 7, 8 and 10 for variable names associated with each code.

\begin{tabular}{|c|c|c|}
\hline Model Theme & $\begin{array}{c}\text { Variables Included for } \\
\text { Obligate Presence }\end{array}$ & $\begin{array}{c}\text { Variables Included for } \\
\text { Facultative Presence }\end{array}$ \\
\hline Universal Model & $\begin{array}{l}\text { X4, X5, X7, X9, X11, X17, } \\
\text { X18, X150, X92, X103, } \\
\text { X134, X79, X99, X69, X41, } \\
\text { FP, LO }\end{array}$ & $\begin{array}{l}\text { X6, X92, X103, X79, } \\
\text { X41, LO }\end{array}$ \\
\hline In-situ variables & $\mathrm{X} 4, \mathrm{X} 5, \mathrm{X} 7, \mathrm{X} 9, \mathrm{X} 11, \mathrm{FP}$ & X6 \\
\hline Mesohabitat Variables & $\mathrm{X} 17, \mathrm{X} 18, \mathrm{LO}$ & LO \\
\hline Watershed Variables & $\begin{array}{l}\text { X150, X92, X103, X134, } \\
\text { X79, X99, X69, X41 }\end{array}$ & $\mathrm{X} 92, \mathrm{X} 103, \mathrm{X} 79, \mathrm{X} 41$ \\
\hline Forest Area & $\begin{array}{l}\text { X17, X18, X92, X103, } \\
\text { X134, X69 }\end{array}$ & X92, X103 \\
\hline Urbanization & $\mathrm{X} 150, \mathrm{X} 99, \mathrm{X} 41$ & $\mathrm{X} 41$ \\
\hline $\begin{array}{l}\text { Urbanization: } \\
\text { Secondary Effects }\end{array}$ & $\mathrm{X} 4, \mathrm{X} 5, \mathrm{X} 9$ & $\mathrm{X} 6$ \\
\hline Moderate Development & $\mathrm{X} 18, \mathrm{X} 79$ & $\mathrm{X} 79$ \\
\hline $\begin{array}{l}\text { Most Predictive \& } \\
\text { Unique }\end{array}$ & $\begin{array}{l}\text { X4, X5, X9, X17, X150, } \\
\text { X134, X79, FP, LO }\end{array}$ & X6, X103, X79, LO \\
\hline
\end{tabular}




\section{Appendix J - Occupancy Modeling Model Weight Sums per Variable}

Appendix J - This table includes the summed AIC weights of each of the variables used in occupancy modeling in relation to each amphibian functional group. Also included is the number of models in which each variable is included (and from which the summed AIC weights were calculated). Variables are ordered from highest AIC weight sum to lowest.

\begin{tabular}{|c|c|c|}
\hline Variable Name & $\begin{array}{c}\text { इAIC } \\
\text { Weight }\end{array}$ & $\begin{array}{c}\# \text { Models } \\
\text { Included } \\
\text { In }\end{array}$ \\
\hline \multicolumn{3}{|l|}{ Obligate Presence } \\
\hline Water Temperature & 0.938 & 4 \\
\hline Water Conductivity & 0.938 & 4 \\
\hline Total Cover per 30 Meter Transect & 0.938 & 4 \\
\hline Patchiness & 0.054 & 4 \\
\hline \% Deciduous Forest (NLCD)(Sub-watershed) & 0.053 & 4 \\
\hline Forest Patch Area & 0.051 & 4 \\
\hline$\%$ Mixed Forest (NLCD)(200 meter buffer) & 0.050 & 3 \\
\hline \% Hardwoods (LC5)(200 meter buffer) & 0.050 & 3 \\
\hline \% Coniferous Forest (NLCD)(100 meter buffer) & 0.050 & 3 \\
\hline Fish Presence & 0.047 & 3 \\
\hline \% Coarse Substrate & 0.044 & 2 \\
\hline \% Riffle Mesohabitat & 0.044 & 2 \\
\hline $\begin{array}{l}\text { \% Herbaceous Vegetation (LC5)(100 meter } \\
\text { buffer) }\end{array}$ & 0.013 & 4 \\
\hline$\%$ Impervious Surface (Sub-watershed) & 0.008 & 4 \\
\hline Land Ownership & 0.007 & 3 \\
\hline \% Paved Surfaces (LC5)(200 meter buffer) & 0.006 & 3 \\
\hline \% Open Development (NLCD)(50 meter buffer) & 0.006 & 3 \\
\hline \multicolumn{3}{|l|}{$\begin{array}{ll}\text { Facultative Presence } \\
\end{array}$} \\
\hline \% Hardwoods (LC5)(200 meter buffer) & 0.921 & 4 \\
\hline $\begin{array}{l}\text { \%Herbaceous Vegetation (LC5)(100 meter } \\
\text { buffer) }\end{array}$ & 0.756 & 4 \\
\hline$\%$ Mixed Forest (NLCD)(200 meter buffer) & 0.731 & 3 \\
\hline \% Open Development (NLCD)(50 meter buffer) & 0.566 & 3 \\
\hline$\%$ Fine Substrate & 0.489 & 4 \\
\hline Land Ownership & 0.411 & 3 \\
\hline
\end{tabular}

